\title{
Tritium Concentration in the F-and H-Area Seeplines and Fourmile Branch at SRS: September 1997 Event and 1989-1997 Summary
}

by

J. Koch

Westinghouse Savannah River Company

Savannah River Site

Aiken, South Carolina 29808

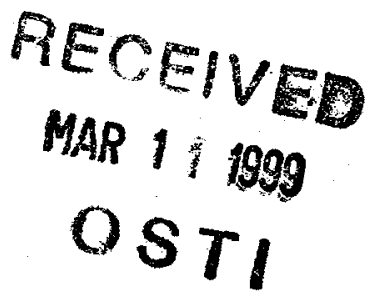

DOE Contract No. DE-AC09-96SR18500

This paper was prepared in connection with work done under the above contract number with the U. S. Department of Energy. By acceptance of this paper, the publisher and/or recipient acknowledges the U.S. Government's right to retain a nonexclusive, royalty-free license in and to any copyright covering this paper, along with the right to reproduce and to authorize others to reproduce all or part of the copyrighted paper. 


\section{Tritium Concentrations in the $\mathrm{F}$ - and $\mathrm{H}$-Area Seeplines and Fourmile Branch at SRS: September 1997 Event and 1989-1997 Summary (U).}

Prepared by:

J. W. Koch II

Environmental Analysis Section

Approved by:

J.B. Gladden, Section Manager

Environmental Analysis Section

Westinghouse Savannah River Company

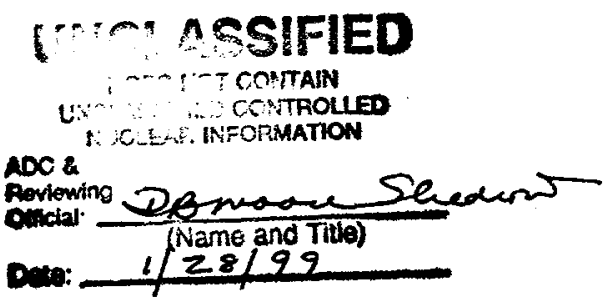
Savannah River Site

Aiken SC 29808

Prepared for the U. S. Department of Energy under contract number DE-AC09-96SR18500 


\section{DISCLAIMER}

This report was prepared as an account of work sponsored by an agency of the United States Government. Neither the United States Government nor any agency thereof, nor any of their employees, makes any warranty, express or implied, or assumes any legal liability or responsibility for the accuracy, completeness, or usefulness of any information, apparatus, product, or process disclosed, or represents that its use would not infringe privately owned rights. Reference herein to any specific commercial product, process, or service by trade name, trademark, manufacturer, or otherwise does not necessarily constitute or imply its endorsement, recommendation, or favoring by the United States Government or any agency thereof. The views and opinions of authors expressed herein do not necessarily state or reflect those of the United States Government or any agency thereof.

This report has been reproduced directly from the best available copy.

Available to DOE and DOE contractors from the Office of Scientific and Technical Information, P.O. Box 62, Oak Ridge, TN 37831; prices available from (615) 576-8401.

Available to the public from the National Technical Information Service, U.S. Department of Commerce; 5285 Port Royal Road, Springfield, VA 22161. 


\section{DISCLAIMER}

Portions of this document may be illegible in electronic image products. Images are produced from the best available original document. 


\section{Tritium Concentrations in the F- and H-Area Seeplines and Fourmile Branch at SRS: September 1997 Event And 1989-1997 Summary (U).}

Prepared by:

J. W. Koch II

Prepared for the U. S. Department of Energy under contract no. DE-AC09-96SR18500 
WSRC-TR-98-00365

This page is intentionally blank 


\section{Table of Contents}

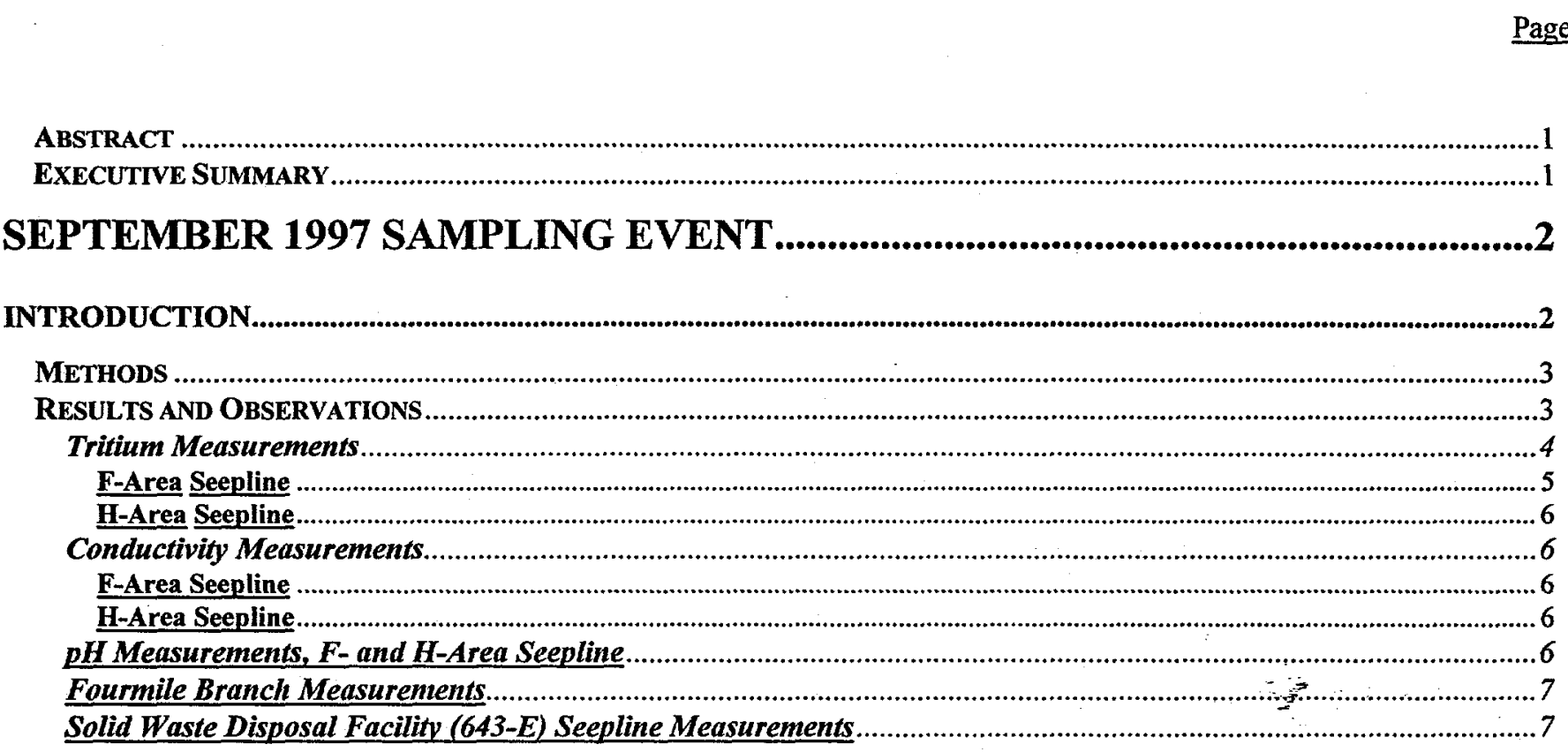

1989 THROUGH 1997 SAMPLING EVENTS ...............................................................8

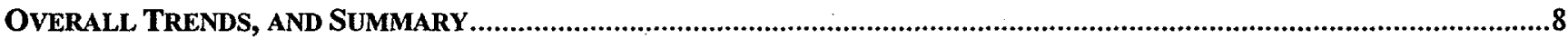

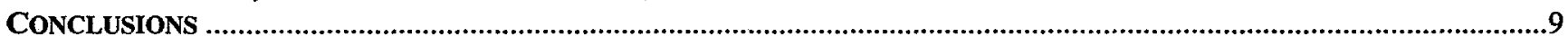

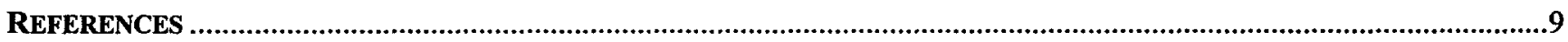

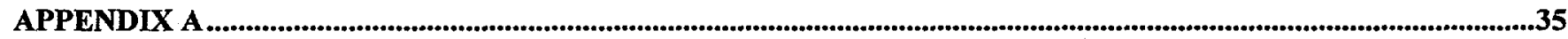

F-AREA SEEPLINE TRITIUM CONCENTRATIONS AND CONDUCtivity PlotTEd By SAMPLING LoCATION 1989-1997 ............35

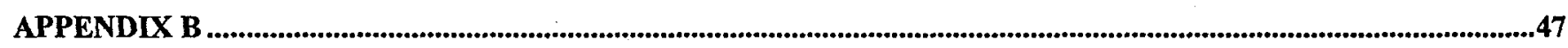

H-AREA SEEPLINE TRITIUM CONCENTRATIONS AND CONDUCTIVITY PlotTEd By SAMPLING LOCATION, 1989-1997...........47

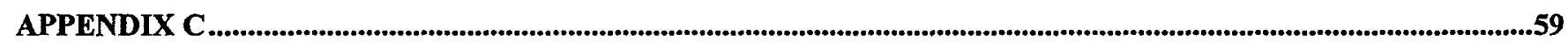

643-E SEEPLINE TRITIUM CONCENTRATIONS AND CONDUCTIVITY PLOTTED BY SAMPLING LOCATIO 1992-1997 .................59

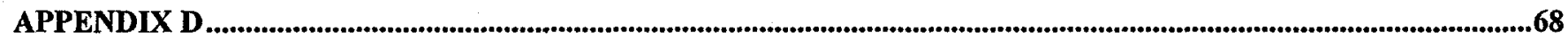

FOURMILE BRANCH TRITIUM CONCENTRATIONS AND CONDUCTIVITY PLOTTED BY SAMPLING LOCATION, 1992-1997........68 


\section{LIST OF FIGURES}

Figure $1 \quad$ Map of F-Area Seepage Basins and Seepline Sampling Locations

Figure 2 Map of H-Area Seepage Basins, Seepline Sampling Locations, and Sampling Locations below 643-E 12

$\begin{array}{lll}\text { Figure } 3 & \text { Groundwater Flow Schematic with Capped Seepage Basins } & 13\end{array}$

Figure $4 \quad$ Groundwater Flow Schematic during Seepage Basin Operation 13

Figure 5 Diagram of the Tritium Plumes Migrating from F- and H-Area Seepage Basins 14

Figure $6 \quad$ Comparison of Monthly Rainfall to the Long Term Average (1961-1994) 14

Figure $7 \quad$ Comparison of Tritium Concentrations for F-Area Seepline Locations 15

Figure $8 \quad$ Comparison of Tritium Measurements for H-Area Seepline Locations 15

Figure 9 Comparison of Conductivity Measurements for F-Area Seepline Locations 16

Figure $10 \quad$ Comparison of Conductivity Measurements for H-Area Seepline Locations 16

Figure $11 \quad$ Comparison of pH Measurements for F-Area Seepline Locations 17

$\begin{array}{lll}\text { Figure } 12 & \text { Comparison of } \mathrm{pH} \text { Measurements for H-Area Seepline Locations } & 17\end{array}$

$\begin{array}{lll}\text { Figure } 13 & \text { Comparison of Tritium Concentrations for Fourmile Branch Locations } & 18\end{array}$

Figure $14 \quad$ Comparison of Conductivity Measurements for Fourmile Branch Locations 18

Figure $15 \quad$ Comparison of pH Measurements for Fourmile Branch Locations 19

Figure $16 \quad$ Comparison of Tritium Concentrations for Fourmile Branch Locations 19

$\begin{array}{lll}\text { Figure } 17 & \text { Comparison of Conductivity Measurements for Seepline below 643-E } & 20\end{array}$

$\begin{array}{lll}\text { Figure } 18 & \text { Comparison of pH Measurements for Seepline below 643-E } & 20\end{array}$

Note: $\quad$ Figures 1 through 18 show the September 1997 sampling event results

Figure $19 \quad$ Tritium and Conductivity Trends for F-Area Seepline (1989-1997) 21

$\begin{array}{lll}\text { Figure } 20 & \mathrm{pH} \text { Trends for F-Area Seepline (1989-1997) } & 21\end{array}$

$\begin{array}{lll}\text { Figure } 21 & \text { Tritium Concentration for F-Area Seepline (1989-1997) }\end{array}$

$\begin{array}{lll}\text { Figure } 22 & \text { Tritium and Conductivity Trends for H-Area Seepline (1989-1997) }\end{array}$

Figure $23 \quad \mathrm{pH}$ Trends for H-Area Seepline (1989-1997) 23

Figure $24 \quad$ Tritium Concentration for H-Area Seepline (1989-1997) 23

$\begin{array}{lll}\text { Figure } 25 & \text { Comparison of Tritium concentrations for Seepline below 643-E (1992-1997) } & 24\end{array}$

Note: $\quad$ Figures 19 through 30 show overall summary results (1989-1997) 


\section{List of Figures (cont'd)}

Figure 26 Comparison of Conductivity concentrations for Seepline below 643-E (1992-1997)

Figure 27

Tritium Concentration for Seepline below 643-E (1992-1997)

Figure 28

Tritium, Conductivity, and pH for Sample Location FMC001F (Fourmile Branch)

Figure 29

Tritium, Conductivity, and pH for Sample Location FMC001H (Fourmile Branch)

Figure 30

Tritium, Conductivity, and pH for Sample Location FMC001H (Fourmile Branch)

Note: Figures 1 through 18 show the September 1997 sampling event results

Figures 19 through 30 show overall summary results (1989-1997) 


\section{List of Tables}

Table 1 Comparison of Monthly Rainfall to the Long Term Average

Table 2 Comparison of F-Area Seepline Measurements for Tritium, Conductivity, and pH for March 1989, March 1997, and September 1997 Sampling Events

Table 3 Comparison of H-Area Seepline Measurements for Tritium, Conductivity, and pH for March 1989, March 1997, and September 1997 Sampling Events

Table 4 Comparison of Fourmile Branch Stream Measurements for Tritium, Conductivity and pH for March 1989, March 1997, and September 1997 Sampling Events

Table 5 Comparison of 643-E Seepline Measurements for Tritium, Conductivity, and pH for March 1989, March 1997, and September 1997 Sampling Events

Table 6

Average Tritium, Conductivity, and $\mathrm{pH}$ Values for F- and H-Area Seeplines (1989-1997)

Table 7 Average Tritium and Conductivity, and pH Values for Seepline Below 643-E (1992-1997)

Table 8

Tritium Concentrations for Fourmile Branch (1992-1997)

Table 9

Sample Collection Summary for F-Area Seepline (1989-1997)

Table 10

Sample Collection Summary for H-Area Seepline, (1989-1997)

Table 11

Sample Collection Summary for 643-E Seepline, (1992-1997)

Note: Tables 1 through 5 are for the September 1997 sampling event comparisons.

Tables 6 through 11 are for the overall trending comparisons for all sampling events 
Tritium Concentrations in the F- and H-Area Seeplines and Fourmile Branch at SRS: September 1997 and March 1989-September 1997 Trending

\author{
J.W. Koch II
}

\begin{abstract}
The Environmental Analysis Section (EAS) of the Savannah River Technology Center (SRTC) conducted a quarterly monitoring program of the Fourmile Branch (FMB) stream and its associated seepline located down gradient from the F- and H-Area Seepage Basins from May 1992 to May 1995. The quarterly tritium survey was changed to a semi-annual schedule in 1996. This report presents the results of the second semi-annual event in 1997 and summarizes the tritium data beginning with the 1989 and 1992 baseline sampling events. The primary focus of this program is to measure and track changes in tritium concentrations. Specific electrical conductivity and $\mathrm{pH}$ were also measured. The results from this survey (September 1997) exhibited similar trends to data from the previous surveys. The results of this tritium survey and stream monitoring data (Looney et al., 1993) indicated that the tritium plume from the past operation of the seepage basins continues to flush from the seeplines and wetlands to Fourmile Branch. The overall summary indicates that the tritium plumes are surfacing in somewhat localized areas along the F-Area and 643-E seeplines. The tritium plume is surfacing more generally throughout the $\mathrm{H}$-Area seepline and not in localized areas.
\end{abstract}

\section{Executive Summary}

In September 1997 the Environmental Analysis Section (EAS) surveyed the Fourmile Branch seepline down gradient from the F- and H-Area Seepage Basins for tritium, specific conductivity, and $\mathrm{pH}$. This survey was the second of two surveys scheduled during FY97 to monitor the movement of contaminants from the basins since closure in 1990. Surface-water samples were collected at 39 of 63 planned locations along the seeplines and from three stream locations along Fourmile Branch. The seepline locations included 18 from the F-Area seepline, 11 from the H-Area seepline, and 7 from the seepline south of 643-E, which is a decommissioned area in the Solid Waste Disposal Facility. Twenty-four of the planned sample locations were dry (eleven along the H-Area seepline, four along the F-Area seepline, and nine from the seepline south of $643-E$ ). It was very unusual to have this many dry sites attributed to dry weather. This was five times the previously highest number of dry sites encountered.
Forty-four of the locations were sampled in 1989 by the Savannah River Technology Center as part of an extensive characterization study (Haselow et al. 1990). Tritium activities in the H-Area seepline in September 1997 were significantly lower than the activities measured by Haselow et al. (1990). The FArea seepline tritium activities were not significantly lower statistically than measured by Haselow. There were seven locations from the September 1997 survey that showed an increase in tritium activity over $10 \%$ above the March 1989 results. The September 1997 conductivity measurements exhibited the same trends as tritium activities in both $\mathrm{F}$ - and H-Area seeplines.

The average $\mathrm{H}$-Area seepline water $\mathrm{pH}$ was approximately the same as the last three surveys that were conducted (September 1996, March 1997, and March 1996). The average F-Area seepline water $\mathrm{pH}$ has shown a gradual increase during these same periods $(0.5 \mathrm{pH}$ units). The results continue to indicate that conditions have somewhat stabilized 
from extremely acid ( $\mathrm{pH}<4.5$ ) to slightly acid (combined $\mathrm{F}$ and $\mathrm{H}$ seepline average of 5.6) which is closer to normal for this type of wetland. The EPA region IV chronic screening values for $\mathrm{pH}$ are 6.5-9.0 (ecological) and 5.0-9.0 for human health.

The seepline south of 643-E, along a tributary of Fourmile Branch, is influenced by tritium migrating from the Burial Ground Complex. The tributary (old F-Area effluent ditch) is a natural drainage that received effluent discharge from F-Area Separations prior to the construction of the engineered effluent canal. The September 1997 tritium concentrations on the east side of the natural drainage ranged from 3 to $1960 \mathrm{pCi} / \mathrm{ml}$ and on the west side from 3100 to $21,100 \mathrm{pCi} / \mathrm{ml}$. The tritium activity measured in the stream of the natural drainage was $21,300 \mathrm{pCi} / \mathrm{ml}$. These results continue to suggest that the tritium outcrop area has been delineated by the sampling locations established on the west side of the drainage channel. Conductivity and $\mathrm{pH}$ measurements taken on both sides of the drainage were similar to those recorded in March 1997, and were within the range of normal values for this wetland. The maximum tritium concentrations have declined from $59,400 \mathrm{pCi} / \mathrm{ml}$ at sample location FHB018 to a maximum of $21,300 \mathrm{pCi} / \mathrm{ml}$ at sample location FHB012 which is the stream sample location that separates the east and west sides of the ditch. Several of the dry sample locations during the September 1997 event were those that typically have low tritium concentrations. For this reason, the ranges of tritium concentrations for the east and west side drainage are biased when compared to previous event results.

\section{Introduction}

Seepage basins in the $F$ and $H$ Areas of SRS received low-level radioactive waste effluent from the chemical separation processes in the General Separation Area, (GSA). The basins retained the effluent and allowed it to be slowly released into the soil. The waste effluent consisted principally of sodium hydroxide, nitric acid, low concentrations of various radionuclides, and some metals (Killian et al., 1985a and 1985b). Discharges of tritiated water to the seepage basins accounted for a majority of the radioactivity (Fenimore and Horton, 1972).

The Savannah River Technology Center conducted an extensive study designed to characterize the shallow groundwater outcropping into Fourmile Branch (FMB) and its associated seepline in 1988 and 1989 (Haselow et al., 1990). As a part of this study, Haselow et al. (1990) analyzed for tritium, and measured $\mathrm{pH}$, and conductivity. Researchers found low $\mathrm{pH}$ and elevated conductivity and tritium values along the seeplines and concluded that contaminants leaching from the $\mathrm{F}$ - and H-Area Seepage Basins were impacting the wetlands below the basins. SRS discontinued discharges to the seepage basins in 1988 and sealed the basins in 1990 to isolate the contaminants from direct rainfall. Scientists hypothesized that afte the elimination of the contaminant source; natural groundwater flow from annual rainfall would flush the remaining contaminant plume out of the shallow groundwater over time. After the contaminant plume in the shallow groundwater is flushed out, the impacted wetland systems immediately down gradient from the basins should recover.

To investigate this hypothesis, a quarterly sampling program was begun in May 1992 and concluded in May 1995. EAS sampled 44 of the seepline locations sampled by Haselow et al. (1990) for tritium, $\mathrm{pH}$, and specific conductivity. The 1997 sampling program was developed to complement sampling of the seepline for selected Appendix IX constituents, Dixon et al. (1995). The Appendix IX program began in July 1992 as a semi-annual program and since 1996 has been conducted annually. The Haselow et al. (1990) results established the baseline against which the results from the quarterly tritium sampling program are compared. These collection points were chosen as the baseline because they are the only data available that were collected before the basin discharges were discontinued. The Haselow et al. (1990) data should be representative of conditions immediately prior to closing the basins.

Later, concern was expressed about the source of tritium and other contaminants that possibly 
emanate from an area in the southwest corner of 643-E rather than from the closed basins. To investigate this possibility, numerous sampling locations on the H-Area seepline south of 643-E were established and were incorporated into the quarterly sampling plans beginning in March 1993.

The objectives of this report are to present the results from the September 1997 sampling event and to trend the results beginning with the baseline sampling events (1989 and 1992) through the September 1997 sampling event.

\section{Methods}

EAS conducted the second of two FY97 sampling events for tritium in September 1997. Sampling locations were the same as those selected in the quarterly tritium surveys. These locations, according to 1989 data, exhibited high and low values for the three variables of concern (tritium, conductivity, and $\mathrm{pH}$ ). Attempts were made to establish even ground coverage along both seeplines. EAS collected 39 samples from the seeplines in $\mathrm{F}$ and $\mathrm{H}$ Area, 18 from the F-Area seepline, 11 from the $\mathrm{H}$ Area seepline, and 7 from the FHB seepline south of 643-E Area. Twenty-two of the seepline locations were dry. One sample was collected from the old effluent stream. EAS also collected three stream samples from locations on Fourmile Branch. Figures 1 and 2 approximate these sampling locations.

Prior to sampling for the first quarterly survey in May 1992, the Health Protection Department (HPD) collected soil samples from several locations along both seeplines and monitored them for gamma radioactivity. HPD did not detect gamma radiation above concentrations of concern. Therefore, EAS selected rubber boots and disposable rubber gloves as protective clothing to prevent skin contact with seepline water during sampling operations.

Seepline sampling locations had been previously marked and labeled with PVC stakes. Samples were collected within a ten-foot radius of the PVC stake by boring a hole into the soil with a small soil auger, generally six inches and not more than eighteen inches deep. To collect water for tritium analysis, 25 milliliter polyethylene sample containers were filled and then capped. The outside of each container was then rinsed with deionized water and sealed in a small polyethylene bag to minimize the possibility of cross contamination. The small bags were then placed in a large polyethylene bag and sealed. General Engineering Laboratories (GEL) performed the tritium analysis for the standard and duplicate samples and the Environmental Monitoring Section (EMS) performed the analysis on split samples and samples with activities exceeding $2000 \mathrm{pCi} / \mathrm{ml}$ total counts. Chain of custody procedures were followed during the collection of all samples.

EAS measured specific conductivity and $\mathrm{pH}$ in situ with conductivity and $\mathrm{pH}$ electrodes (WSRC Procedure Manual L14.1, 1992a and 1992b). The electrodes were rinsed with detonized water after each sampling. All sampling equipment was thoroughly rinsed with deionized water at the end of each day.

\section{Results and Observations}

Parameters measured at seepline sampling locations fluctuate throughout the year. Seepline measurements were taken on water collected from fixed locations at the initial point of outcropping, or toe, of the contaminant plume in the streamside wetland. Since the plume is dynamic (i.e. influenced by weather and other activities in the area) seepline monitoring is sensitive to both long term changes and seasonal/transient influences. Climatic and seasonal conditions, especially amounts of rainfall, influence measured concentrations. Groundwater flow paths in $F$ and $H$ Area are complex, as illustrated in Figures 3 and 4. Recharge to the groundwater is primarily due to infiltration of rainwater (rainfall minus runoff and evapotranspiration). Groundwater then moves laterally, down and towards Fourmile Branch and its tributaries.

As the water travels toward the Fourmile Branch, additional infiltration forces up-gradient water deeper. Near Fourmile Branch, the flow lines rise to the surface, emerging between the seepline and the stream (this acts as the groundwater "drain"). This 
typical vertical trajectory, a path curving downward near the groundwater divide and then upward into draining surface water, is shown as flow lines on Figures 3 and 4.

Figure 3 shows the flow lines without contaminated water from the seepage basins and Figure 4 shows the addition of contaminated flow lines resulting from $\mathrm{F}$ and $\mathrm{H}$ Area operation of the basins. The theoretical plume geometry was confirmed by the real vertical profile of the F-Area Seepage Basin plume based on the detailed grid wells available in the 1970s (Looney et al., 1993). Changes in the water balance in the area influence the flow velocity and tend to move the plume either deeper or shallower and cause the location of the contaminated water to move. This is particularly important to data interpretation if the "toe" of the plume is shifting relative to the fixed sample locations. Figure 5 summarizes the projected changes in the plume based on a range of transitory activities. Increased rainfall (or other activities that increase infiltration such as harvesting trees) results in increased plume velocity and movement downward and away from the seepline. This decreases contaminant concentrations at the seepline sampling locations. Less infiltration decreases plume velocity and causes the plume to move upward and outcrop closer to the basins. This results in increased contaminant concentrations, as measured at the seepline sampling locations.

Low rainfall for a few months prior to sampling is expected to increase constituent concentrations, and high rainfall decreases constituent concentrations in the shallow groundwater at the seepline intercept. Rainfall measured at the SRS weather station in F Area for March 1997 through August 1997 was 62.8 $\mathrm{cm}$. The average long-term rainfall for this same period was $70.2 \mathrm{~cm}$. Thus, rainfall in the sampling area was about much less than normal for the few months prior to this sampling event. Figure 6 compares 1997 rainfall to the long-term average (1961 to 1994). It is hypothesized that below average rainfall observed in the area for this period would cause contaminant concentrations to increase at sample locations closer to the basins and to decrease at the more distant locations. Note that the direction of plume flow always remains the same, only the flow velocity and outcrop location changes relative to the changes in infiltration.

Tritium concentrations at nine sample locations were above the March 1989 readings, with these sample locations showing an average tritium activity increase of $512 \mathrm{pCi} / \mathrm{ml}$. Generally, these are the most distant sample location points from the closed basins along Fourmile Branch. Figures 7 through 12 show comparisons of March 1989 with March 1997 and September 1997 tritium, conductivity, and $\mathrm{pH}$ measurements for locations along the F- and H-Area seepline. Data for the first fourteen surveys can be found in Dixon, Rogers, and Looney (1992, 1993a, 1993b, 1993c, 1993d and 1993e and 1994), Rogers et al. (1994a, 1994b, and $1994 \mathrm{c})$ and Koch and Dixon (1994, 1995, 1996, and 1997). Figures 13 through 15 show the data for the Fourmile Branch stream locations. Figures 16 through 18 show the data for the sampling locations along the old effluent seepline and include one stream sample from the stream channel south of 643-E. These sampling locations were identified with the prefix FHB.

\section{F- and H-Area Seepline Tritium Measurements}

Figures 7 and 8 show tritium activities at $F$ and $H$ Areas for the September 1997 sampling event. Tritium concentrations increased by greater than $100 \mathrm{pCi} / \mathrm{mL}$ at 13 sample locations, while 16 locations either decreased or were relatively unchanged compared to the March 1997 sampling event. There were fifteen dry sites. This is a much greater number of dry sites than previously encountered. It can be attributed to the unusually dry month prior to conducting the sampling event. Overall, sampling has shown a declining trend in tritium concentrations at the $\mathrm{F}$-and $\mathrm{H}$-Area seeplines (Figures 19 and 20).

It is important to note that total tritium fluxes to the wetlands and FMB have steadily declined since basin closure (Looney et al., 1993) and that overall results of the tritium survey support this finding. Differences in tritium concentrations measured at 
seepline sampling locations from one sampling event to the next represent seasonal variability and variable rainfall as well as changes due to the plume flushing from the wetland system. Variability may also result from reduction in plume size along margins.

\section{F-Area Seepline}

September 1997 tritium values in the F-Area seepline ranged from 9 to $8,380 \mathrm{pCi} / \mathrm{ml}$ (Figure 7 and Table 2). Four of the 22 sampling locations were dry, and six sampling locations had a tritium activity exceeding the 1989 baseline measurements by more than ten percent. No sample exceeded the maximum value of $14,000 \mathrm{pCi} / \mathrm{ml}$ measured in March 1989 at this seepline.

As with data from previous sampling events, a Wilcoxon signed-rank test was conducted to compare September 1997 tritium activities to March 1989 baseline activities. The Wilcoxon signed-rank test uses the sign and the magnitude of the rank of the differences between pairs of measurements to compare nonparametric data (Daniel, 1978). This test was chosen because it allows comparisons of paired data without assumptions of normality. If the $P$ value is less than or equal to 0.05 , then the September 1997 tritium concentrations are significantly different from the March 1989 baseline tritium concentrations. The results from this test gave a $P$ value $=0.099$. Consequently, this test shows that the September 1997 concentrations were not significantly lower than the 1989 concentrations for this seepline. This result could be due to the somewhat higher than normal tritium concentrations observed from the movement of the plume's toe due to dry weather

Examining the figures in Appendix A reveals the bulk of contaminants are located between sample locations FSP040 and FSP235. Very little change in tritium concentrations is occurring east of location FSP040 or west of FSP235.

\section{H-Area Seepline}

Tritium values in the H-Area seepline for September 1997 ranged from 38 to $8,120 \mathrm{pCi} / \mathrm{ml}$ (Figure 8 and Table 3). Eleven of the 22 sampling locations were dry, and three sampling locations had tritium activities that exceeded the 1989 baseline measurements by more than ten percent. These locations, HSP071, HSP097, and HSP103 are among the farthest locations from the closed basins. No sample exceeded the maximum value of 24,000 $\mathrm{pCi} / \mathrm{ml}$ measured in March 1989 at this seepline.

Figure 22 shows the downward trend of tritium concentrations and the conductivity trends in this area. It presents the mean of the tritium concentrations from each sampling event beginning with the March 1989 baseline event (Table 6). Figure 23 shows the $\mathrm{pH}$ trends using the mean $\mathrm{pH}$ of each sampling event.

As with data from $\mathrm{F}$ Area, a Wilcoxon signed-rank test was conducted to compare September 1997 tritium activities to March 1989 activities. The result shows that the September 1997 concentrations were significantly less $(P=0.029)$ than the 1989 concentrations for this seepline.

It's worth noting that when examining the individual plots in Appendix B, sampling locations closest to the closed basins show a distinct decreasing trend. The locations furthest from the closed basins show an increasing trend. This supports the hypothesis that the contaminants are flushing from the system. Eventually the contaminant concentrations at these sample locations are expected to begin decreasing.

\section{F- and H-Area Seepline Conductivity Measurements}

\section{F-Area Seepline}

Conductivity measurements at the F-Area seepline in September 1997 ranged from 32 to $1,297 \mu \mathrm{S} / \mathrm{cm}$ (Figure 9, Table 2). Due to the variability of conductivity measurements, only differences of 100 
$\mu \mathrm{S} / \mathrm{cm}$ or more are considered significant. Of the 18 locations sampled at the F-Area seepline, three of the locations measured more than $100 \mu \mathrm{S} / \mathrm{cm}$ above the 1989 baseline measurements. A comparison of the results in Figures 7 and 9 suggests that conductivity follows the same general trends as the tritium activities. Using a Spearman rank correlation test for nonparametric data, the probability that tritium and conductivity exhibited independent trends was low, $(\mathrm{P}<0.001)$. The Spearman rank correlation coefficient was calculated to be $\mathrm{r}_{\mathrm{S}}=$ 0.89 , suggesting that the two parameters behave dependently. This similarity of trends between conductivity and tritium is consistent with past results. In past tritium surveys, 1992 through March 1997, this correlation has been positive and significant. A rank correlation coefficient of 1.0 is a perfect correlation between variables.

\section{H-Area Seepline}

Conductivity measurements in September 1997 at the H-Area seepline ranged from 49 to $399 \mu \mathrm{S} / \mathrm{cm}$ (Figure 10 and Table 3). Only one of the sampling locations, had a measurement of more than 100 $\mu \mathrm{S} / \mathrm{cm}$ above the 1989 baseline measurements. The Spearman rank correlation test was used to investigate the correlation of tritium activities and conductivity values. The probability that the two parameters exhibited independent trends was low on this seepline also $(P<0.002)$. The rank correlation coefficient $\left(r_{S}=0.82\right)$ was less than that for $F$ Area suggesting a weaker correlation but still dependent behavior between variables. In past tritium surveys, 1992 to 1996, this correlation has been positive and significant.

\section{F- and H-Area Seepline pH Measurements}

F-Area seepline $\mathrm{pH}$ values ranged from 3.1 to 6.8 , with an average value of 5.2 (Figure 11, Table 2). $\mathrm{H}$ - Area $\mathrm{pH}$ values ranged from 5.0 to 6.4 , with an average of 6.0 (Figure 12 and Table 3). The $\mathrm{pH}$ for the entire seepline ( $F$ and $H$ Areas combined) averaged 5.5. This represents an increase of 0.6 units over the 4.9 average in 1989 and is equal to the overall average for the sampling event. An increase in pH will effect the solubility of metals in the soil, which should improve the soil water chemistry and enhance the recovery of wetland vegetation stressed indirectly by low $\mathrm{pH}$.

Aluminum concentrations measured along the seepline in 1989 were high enough to be toxic to plants (Haselow et al., 1990). Increases in $\mathrm{pH}$ from an average of 4.9 (in 1989) have likely reduced the amount of aluminum in solution and thereby reduced it as a possible source of plant toxicity. Concentrations of aluminum and other metals measured along the seepline in March 1997 were substantially lower than 1989 concentrations, consistent with the observed $\mathrm{pH}$ (Koch and Dixon, 1998). Field observations have revealed that vegetation in most of the stressed areas is making noticeable recovery (Nelson and Irwin, 1994; Nelson and Rogers, 1995). Studies have also shown that the toxicity of these areas is decreasing, (Nelson and Westbury, 1994; Westbury and Nelson, 1994).

\section{Fourmile Branch Measurements}

Figures 13 through 15 show the tritium, conductivity, and $\mathrm{pH}$ values for the Fourmile Branch stream sampling locations. Table 4 provides the data used in the figures. Tritium activities at these locations in September 1997 ranged 16 to 577 $\mathrm{pCi} / \mathrm{ml}$. These values continue to show that tritium concentration increase as you sample further downstream along this seepline (as the seepline water enters the channel of Fourmile Branch). Conductivity measurements ranged from 62 to 66 $\mu \mathrm{S} / \mathrm{cm}$ and $\mathrm{pH}$ ranged from 6.1 to 6.8 .

\section{Solid Waste Disposal Facility (643-E) Seepline Measurements}

The graphs in Figures 16 through 18 show tritium, conductivity, and $\mathrm{pH}$ values for the seepline and stream sampling locations south of 643-E, which is part of the Solid Waste Disposal Facility. Table 5 provides the data used in the figures. This seepline is along the natural drainage (old F-Area effluent ditch) that was used to discharge effluent from $\mathrm{F}$ - 
Area separations prior to the construction of the engineered effluent canal.

Only one sample was collected out of eight from the east side of the drainage. The other seven sites were dry from a month of unusually dry weather prior to sampling. The tritium activity for this location, FHB020, was $5 \mathrm{pCi} / \mathrm{ml}$. Three of the seven sites on the west side of the drainage were dry. Of the remaining four, tritium activities ranged from 1,500 to $21,100 \mathrm{pCi} / \mathrm{ml}$. The tritium activity at the stream location in the drainage (FHB012) was 21,300 $\mathrm{pCi} / \mathrm{ml}$.

In September 1997, $\mathrm{pH}$ values ranged from 3.6 to 5.3, with an average of 4.8. Conductivity measurements on both sides of the drainage were near background at most locations and ranged from 35 to $53 \mu \mathrm{S} / \mathrm{cm}$. Conductivity values are typical of the conductivity values being reported in the water table wells in the vicinity of the old F-Area effluent ditch (EMS, 1996). The Spearman rank correlation test was not conducted due to the number of dry sites. Past Spearman rank correlation test results showed no correlation between conductivity and tritium.

The tritium results were consistent with the Haselow et al. (1990) results for the west side sample locations of the 643-E seepline, particularly near location HSP103. Haselow et al. (1990) found that down gradient from $643-\mathrm{E}$, conductivity values were near background whereas tritium concentrations were elevated. This finding was attributed to tritiated wastes deposited in 643-E. Tritium activities measured along the seepline down gradient of 643-E (particularly sample points on the west side of the drainage) suggest that tritium migrating from 643-E and outcropping in this area was substantial. The detection of tritium on the west side (as opposed to the east side of the drainage) suggested that soil material placed in the northern reaches of the natural drainage forced the tritium plume to outcrop down gradient. It appears that the groundwater containing tritium is moving below the fill material and outcropping on the west side of the drainage channel. The results suggest that the sampling locations on the west side of the drainage have delineated the tritium plume with the center located at or near FHB018.

Figure 30 shows the tritium data from all the sampling events for this seepline area beginning with the 1992 sampling event. The higher tritium activity locations occur at four locations, all on the west side of the drainage. These locations are FHB013, 017, 018, and 019.

\section{Overall Trends, and Summary}

\section{F-Area Seepline}

Figure 19 shows the downward trend of tritium concentrations for the F-Area seepline and the conductivity trends. It shows the mean tritium and conductivity concentrations from each sampling event beginning with the March 1989 baseline event through the September 1997 sampling event (Table 6). Each sampling event since 1989 has shown a statistically significant decrease in tritium concentrations when compared to the 1989 baseline event. Figure 20 shows the $\mathrm{pH}$ trends using the mean $\mathrm{pH}$ of each sampling event.

Figure 21 shows the tritium concentrations for all the sampling events at the F-Area seepline. It indicates that a majority of the tritium measured appears at eight of the 22 sample locations. These locations, are FSP019, 026, 032, 034, 035, 040, 204, and 213. Very little of the tritium plume has been detected east of sample location FSP040 or south and west of sample location FSP0213. It also appears that two distinct groupings of sample locations delineate the bulk of the tritium plume from the seepage basins. Road C-4 separates these two groupings.

Table 9 shows the sample collection summary for this seepline from 1989-1997.

\section{H-Area Seepline}

Figure 22 shows the downward trend of tritium concentrations for the H-Area seepline and the conductivity trends. This figure shows the mean tritium and conductivity concentration from each 
sampling event beginning with the March 1989 baseline event through the September 1997 sampling event (Table 6). Figure 23 shows the $\mathrm{pH}$ trends using the mean $\mathrm{pH}$ of each sampling event. Each sampling event since 1989 has shown a statistically significant decrease in tritium concentrations when compared to the 1989 baseline event.

Figure 24 shows the tritium concentrations from all the sampling events conducted for the H-Area seepline. The sample locations having the highest and lowest tritium values over the entire sampling interval (1989 to 1997) can be seen from examining this figure.

Table 10 shows a sample collection summary for this seepline from 1989 through 1997.

$\underline{643-E}$

Figures 25 to 27 summarize the tritium concentrations, conductivity, and $\mathrm{pH}$ measurements of each sampling event. The delineation of the contamination is apparent in Figure 25. Figure 27 shows that a majority of the contaminant plume appears at four sample locations. These locations are on the west side of the drainage and are identified as FHB013, 017, 018, and 019.

Table 11 shows a sample collection summary for this seepline area from 1992 through 1997.

\section{Fourmile Branch}

Figures 28 to 30 show the tritium concentrations, conductivity, and $\mathrm{pH}$ measurements for the Fourmile Branch sample locations from 1992 to 1997. Each point represents the actual concentration or reading and is not an average value.

\section{Conclusions}

The difference in tritium concentrations between sampling events is represented by rainfall and seasonal variability; as well as changes from the contaminant plume flushing from the wetland system. Conclusions about tritium fluxes into the wetlands and FMB should consider the complexity of the groundwater system. They should also be based on long-term surface water, seepline, and groundwater monitoring data and not on quarterly changes in concentrations at seepline monitoring locations. No correction has been made for tritium decay because of the short time period between sampling events.

\section{F- and H-Area Seeplines, and Fourmile Branch}

- Tritium concentrations measured at most locations during September 1997 remained relatively unchanged compared to the previous sampling event, but were significantly lower than the 1989 baseline tritium concentrations.

- Total tritium fluxes to the wetlands and FMB have steadily declined since basin closure (Looney et al., 1993). Overall results from the September 1997. tritium survey support this finding. These findings continue to support the hypothesis that the tritium plume in $\mathrm{F}$ and $\mathrm{H}$ Area is being flushed from the shallow groundwater.

- A majority of the tritium detected along the FArea seepline appeared at two localized areas (i.e., eight of the 22 sample locations). These eight sample locations are FSP019, 026, 032, 034, 035, 040, 204 and 213.

- Two tritium results from the September 1997 survey were above $20,000 \mathrm{pCi} / \mathrm{ml}$. Both of these occurred in the drainage area of the old F-Area effluent ditch, 643E seepline.

\section{Solid Waste Disposal Facility (643-E) Seepline}

Data from 16 seepline locations south of the 643-E Area indicated that tritium migrating from $643-\mathrm{E}$ is outcropping at the F- Area effluent ditch, particularly on the west side of the stream channel. It appeared that sampling locations on the west side of the ditch have delineated the tritium outcrop area with the present climatic and hydrologic conditions. 
- Data indicated tritium concentrations have decreased over the past nine sampling events.

- A major portion of the tritium detected was on the west side of the drainage at four sample locations. These four sample locations are FHB013, 017, 018, and 019.

- The tritium concentrations have steadily decreased at the west side sample locations since August, 1993.

\section{References}

Daniel, W.W. 1978. Applied Nonparametric Statistics. Houghton Mifflin Company, Boston, MA.

Dixon, K.L. and V.A. Rogers. 1992a. Results of the First Quarter Tritium Survey of the F- and HArea Seeplines: May 1992. WSRC-TR-92-304, Westinghouse Savannah River Company, Savannah River Technology Center, Aiken, SC

Dixon, K.L. and V.A. Rogers. 1993b. Results of the Second Quarter Tritium Survey of the F- and HArea Seeplines: September 1992. WSRC-TR93-129, Westinghouse Savannah River Company, Savannah River Technology Center, Aiken, SC.

Dixon, K.L. and V.A. Rogers. 1993c. Results of the Third Quarter Tritium Survey of the F- and HArea Seeplines: December 1992. WSRC-TR-93284, Westinghouse Savannah River Company, Savannah River Technology Center, Aiken, SC.

Dixon, K.L. and V.A. Rogers. 1993d. Results of the Fourth Quarter Tritium Survey of the F- and HArea Seeplines: April 1993. WSRC-TR-93526, Westinghouse Savannah River Company, Savannah River Technology Center, Aiken, SC.

Dixon, K.L. and V.A. Rogers. 1993e. Results of the Quarterly Tritium Survey of Fourmile Branch and its Seeplines in the F- and H-Areas of SRS: June 1993. WSRC-TR-93-656, Westinghouse Savannah River Company, Savannah River Technology Center, Aiken, SC.

Dixon, K.L., and V.A. Rogers, and B.B. Looney. 1994. Results of the Quarterly Tritium Survey of Fourmile Branch and its Seeplines in the F and $\mathrm{H}$ Areas of SRS: September 1993 (U) WSRC-TR-94-0286-ESS, Westinghouse Savannah River Company, Savannah River Technology Center, Aiken, SC.

Dixon, K.L., J.W. Koch, and V.A. Rogers. 1995. Semi-Annual Sampling of Fourmile Branch and Its Seeplines in the $F$ and $H$ Areas of SRS: February 1993, July 1993, April 1994. (U) WSRC-TR-95-0454, Rev. 1, Westinghouse Savannah River Company, Savannah River Technology Center, Aiken, SC.

Environmental Monitoring Section. 1993. The Savannah River Site's Ground Water Monitoring Program, Second Quarter Report. ESH-EMS-930097, Westinghouse Savannah River Company, Aiken SC.

Fenimore, J.W. and J.H. Horton. 1972. Rating History and Environmental Effects of Seepage Basins in Chemical Separations Areas of the Savannah River Plant. DPST-72-548, E.I. du Pont de Nemours and Company, Savannah River Laboratory, Aiken, SC.

Haselow, J.S., M. Harris, B.B. Looney, N.V. Halverson, and J.B. Gladden. 1990. Analysis of Soil and Water at the Fourmile Branch Seepline Near the F and H Area of SRS (U). WSRC-RP90-0591, WSRC-TR-92-304, Westinghouse Savannah River Company, Savannah River Technology Center, Aiken, SC. Savannah River Laboratory, Aiken, SC.

Killian, T.H., N.L. Kolb, P. Corbo, and I.W. Marine. 1985a. F-Area Seepage Basins. DPST-85-704, E.I. du Pont de Nemours and Company, Savannah River Laboratory, Aiken, SC. 
Killian, T.H., N.L. Kolb, P. Corbo, and I.W. Marine. 1985b. H-Area Seepage Basins. DPST-85-706, E.I. du Pont de Nemours and Company, Savannah River Laboratory, Aiken, SC.

Koch, J.W. and K.L. Dixon. 1994. Results of the Quarterly Tritium Survey of Fourmile Branch and its Seeplines in the F and H Areas of SRS: December 1994. (U) WSRC-TR-95-0300, Westinghouse Savannah River Company, Savannah River Technology Center, Aiken, SC.

Koch, J.W. and K.L. Dixon. 1995. Results of the Quarterly Tritium Survey of Fourmile Branch and its Seeplines in the F and H Areas of SRS: May 1995. (U) WSRC-TR-95-0369, Westinghouse Savannah River Company, Savannah River Technology Center, Aiken, SC.

Koch, J.W. and K.L. Dixon. 1996. Results of the Tritium Survey of Fourmile Branch and its Seeplines in the F and H Areas of SRS: March 1996 WSRC-TR-96-0215, Westinghouse Savannah River Company, Savannah River Technology Center, Aiken, SC.

Koch, J.W. and K.L. Dixon. 1997. Results of the Tritium Survey of Fourmile Branch and its Seeplines in the F- and H-Areas of SRS: September 1996 and 1989-1996 Trending (U) WSRC-TR-97-0109, Westinghouse Savannah River Company, Savannah River Technology Center, Aiken, SC.

Koch, J.W. and K.L. Dixon. 1997. Tritium Concentrations in the F- and H-Area Seeplines and Fourmile Branch at SRS: March 1997 and 1989-1997 Trending (U). WSRC-TR-97-0359, Westinghouse Savannah River Company, Savannah River Technology Center, Aiken, SC.

Koch, J.W. and K.L. Dixon. 1998. Comprehensive Sampling of Fourmile Branch and Its Seeplines in the F and $H$ Areas of SRS: June 1996, and $\begin{array}{ll}\text { March } 1997 & \text { (U) WSRC-TR-98-00287, }\end{array}$ Westinghouse Savannah River Company, Savannah River Technology Center, Aiken, SC.
Looney, B.B., J.S. Haselow, C.M. Lewis, M.K. Harris, D.E. Wyatt, C.S. Hetrick. 1993. Projected Tritium Releases from F \& $\mathrm{H}$ Area Seepage Basins and the Solid Waste Disposal Facilities to Fourmile Branch (U). WSRC-RP93-459, Westinghouse Savannah River Company, Savannah River Technology Center, Aiken, SC. Savannah River Laboratory, Aiken, $\mathrm{SC}$.

Nelson, E.A. and Irwin, J.E. 1994. Current Vegetation Characteristics within Tree-Kill Zones of $\mathrm{F}$ and $\mathrm{H}$ Areas (U) WSRC-TR-940203 Westinghouse Savannah River Company, Savannah River Technology Center, Aiken, SC.

Nelson, E. A. and Westbury, H.M. Jr. 1994 Lettuce Seed Germination and Root Elongation Toxicity Evaluation of the F-Area Seepline Soils (U) WSRC-TR-94-0510 Westinghouse Savannah River Company, Savannah River Technology Center, Aiken, SC.

Nelson, E.A. and Rogers, V.A. 1995. Survival of Planted Tupelo Seedlings in F- and H-Area Tree-Kill Zones (U) WSRC-TR-95-0025 Westinghouse Savannah River Company, Savannah River Technology Center, Aikken, SC.

Rogers, V.A., K.L. Dixon, and B.B. Looney. 1994a. Results of the Quarterly Tritium Survey of Fourmile Branch and its Seeplines in the F and H Areas of SRS: December 1993. (U) WSRCTR-94-0342, Westinghouse Savannah River Company, Savannah River Technology Center, Aiken, SC.

Rogers, V.A., KL. Dixon, and B.B. Looney. 1994 b. Results of the Quarterly Tritium Survey of Fourmile Branch and its Seeplines in the $\mathrm{F}$ and H Areas of SRS: March 1994. (U) WSRC-TR94-0408, Westinghouse Savannah River Company, Savannah River Technology Center, Aiken, SC. 
Results of the Tritium Survey of Fourmile Branch andits Seeplines in the F and H Areas of SRS: September 1997 and 1989-1997 Summary

Rogers, V.A., K.L. Dixon, and B.B. Looney. 1994c.

Results of the Quarterly Tritium Survey of Fourmile Branch and its Seeplines in the F and H Areas of SRS: June 1994. (U) WSRC-TR-940441, Westinghouse Savannah River Company, Savannah River Technology Center, Aiken, SC.

Westbury, H.M. Jr. and Nelson, F.A. 1994. Plant Community Development Within the F- and $\mathrm{H}$ Area Tree-Kill Zones (U) WSRC-TR-94-0544 Westinghouse Savannah River Company, Savannah River Technology Center, Aiken, SC. 


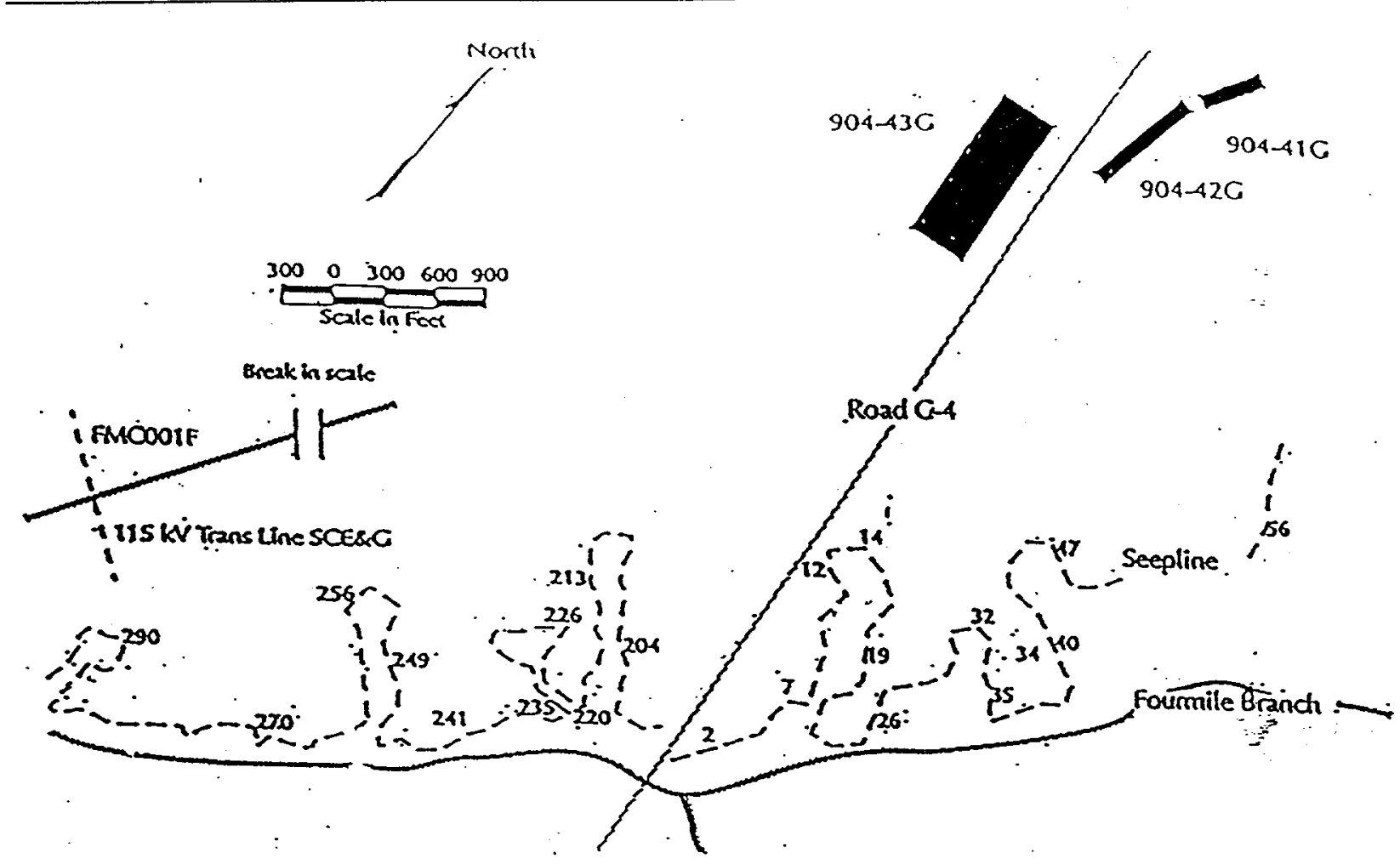

Figure 1. Location of F-Area Seepage Basins and Seepline Sampling Points.

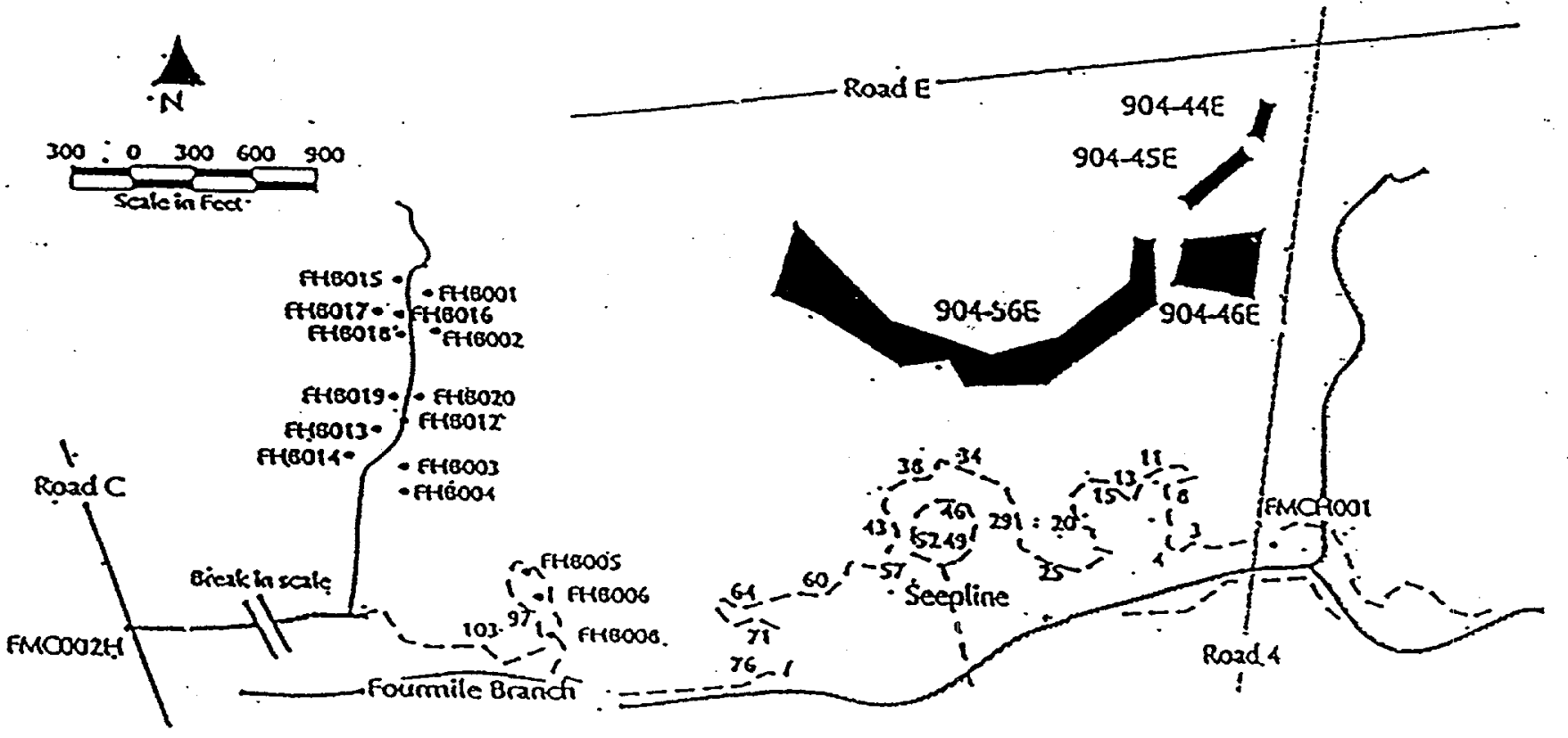

Figures 2. Location of H-Area Seepage Basins and Seepline Sampling Points and FHB Sampling Points. 


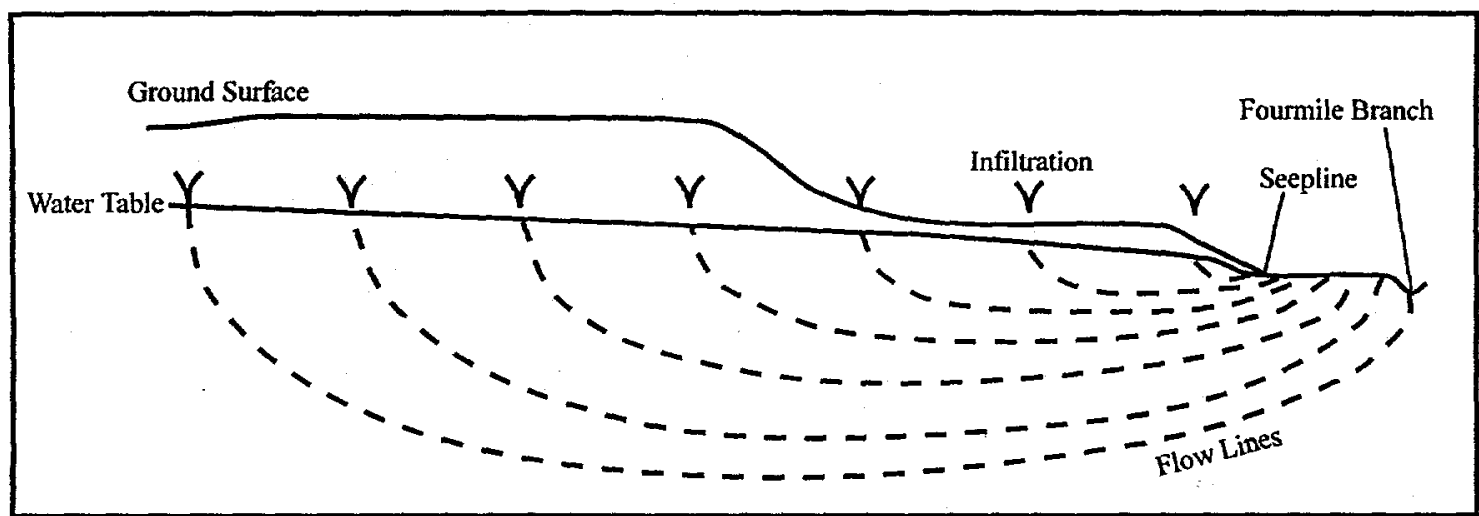

Legend
$-\quad-$ Flowline

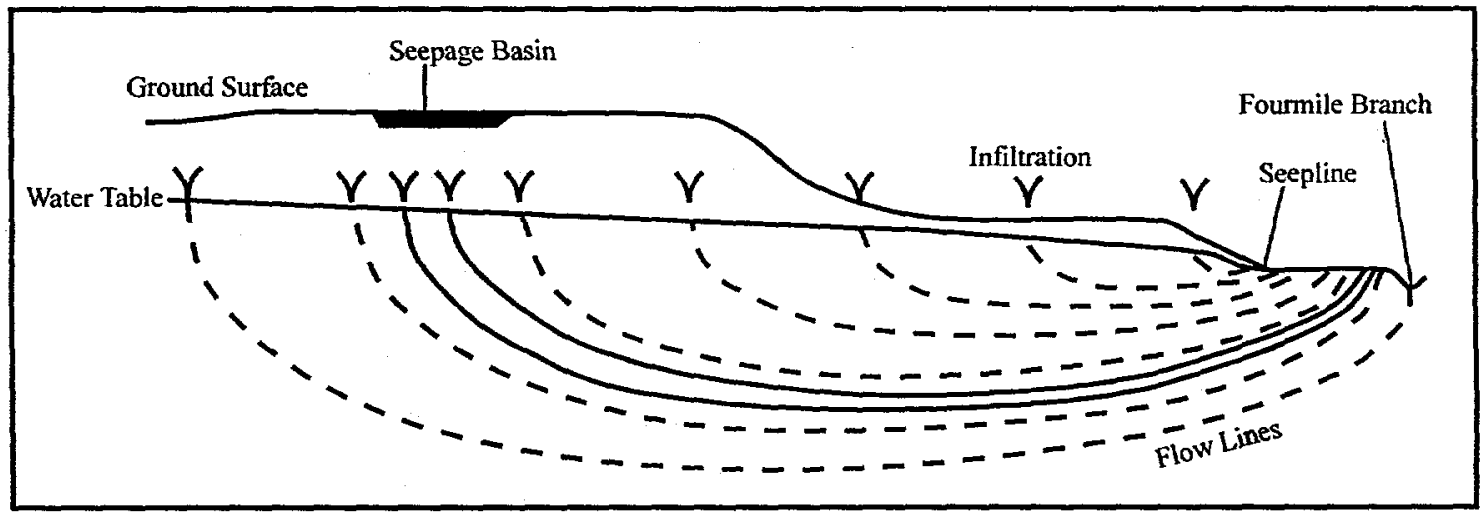

Legend

- - Flowline

Contaminated

Flowline

Figures 3 and 4. Schematic diagram of flow lines before and after closure of seepage basins. 


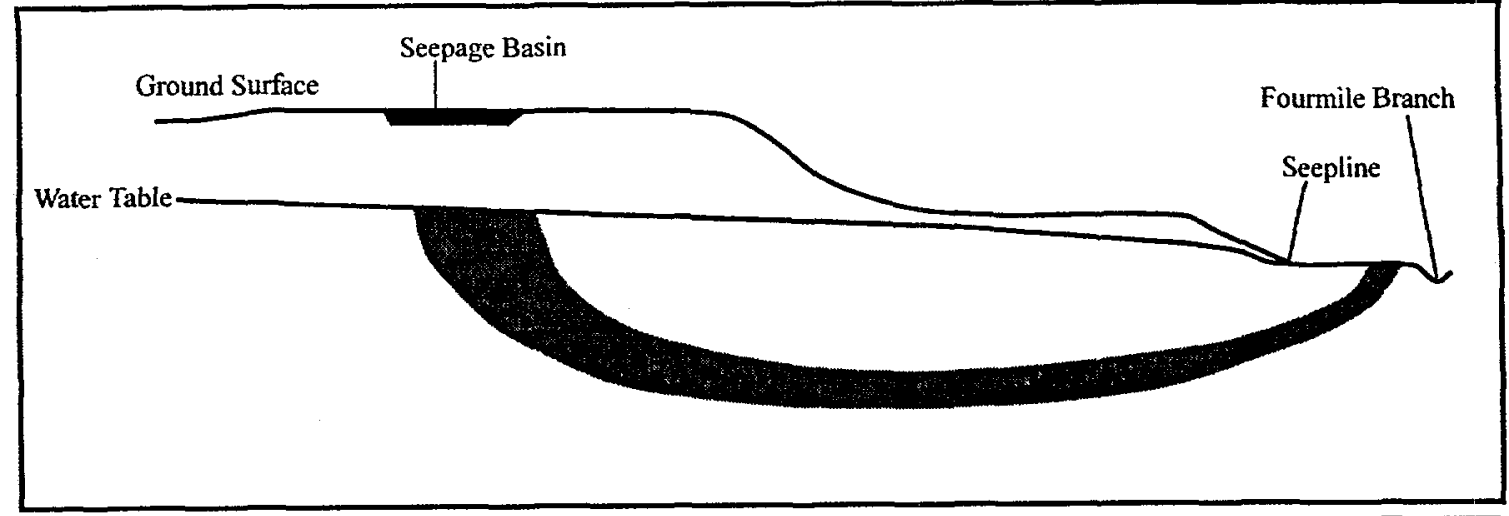

Plume Velocity Impacts:
Close Basins $\rightarrow$
More Rainfall $\rightarrow$
Less Rainfall

\begin{tabular}{|c|}
\hline Plume Depth Impacts: \\
Close Basins $\uparrow$ \\
More Rainfall $\downarrow$ \\
Less Rainfall $\uparrow$
\end{tabular}

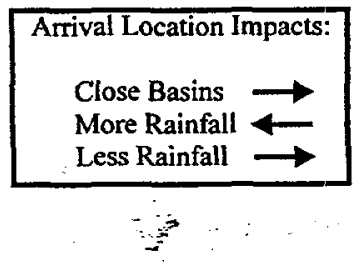

Figure 5. Schematic Diagram of the Tritium Plume Migrating from F- and H-Area Seepage Basins and rainfall effects

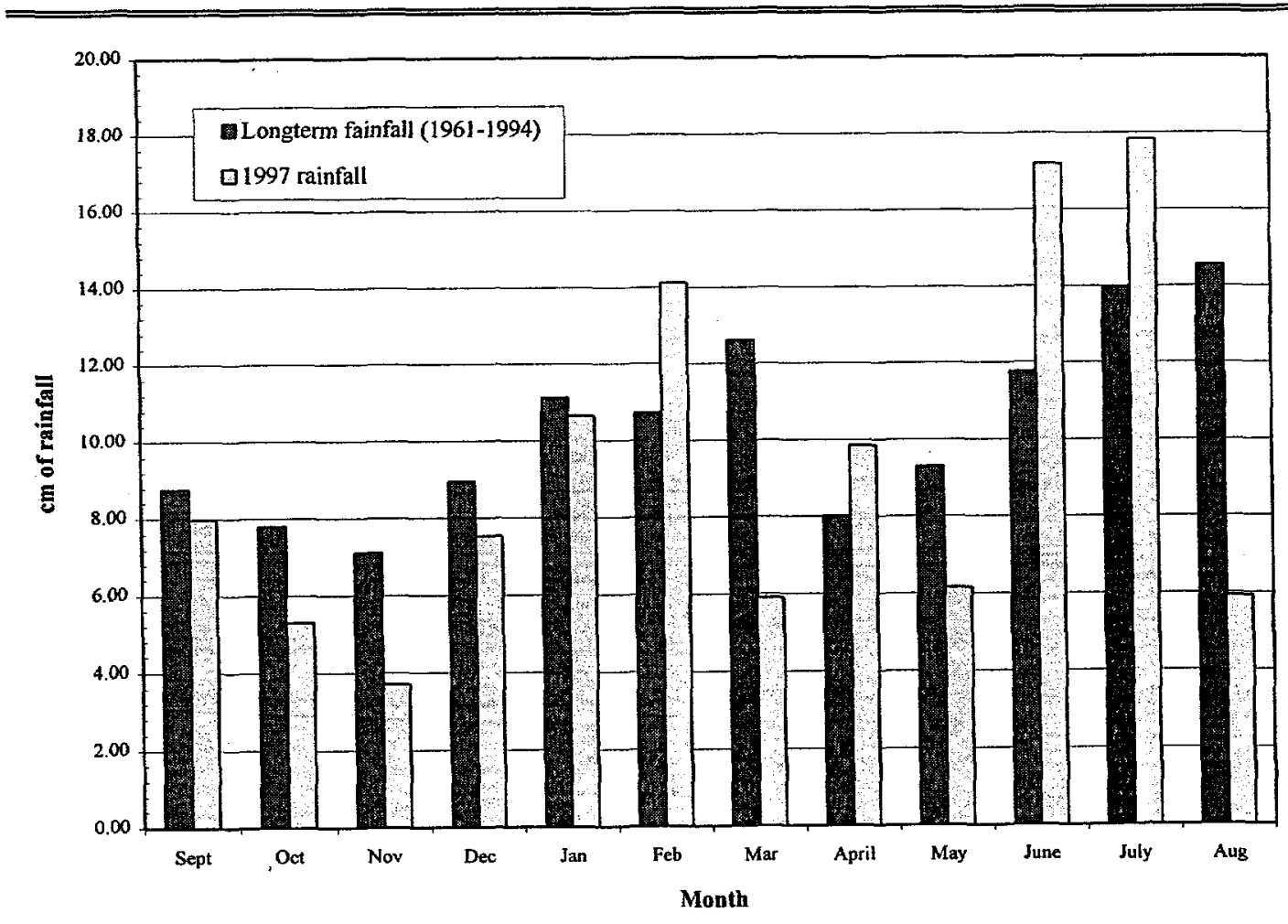

Figure 6. Comparison of March 1996 through February 1997 Monthly Rainfall to the Long Term Average (19611994) for the F-Area Weather Station. 


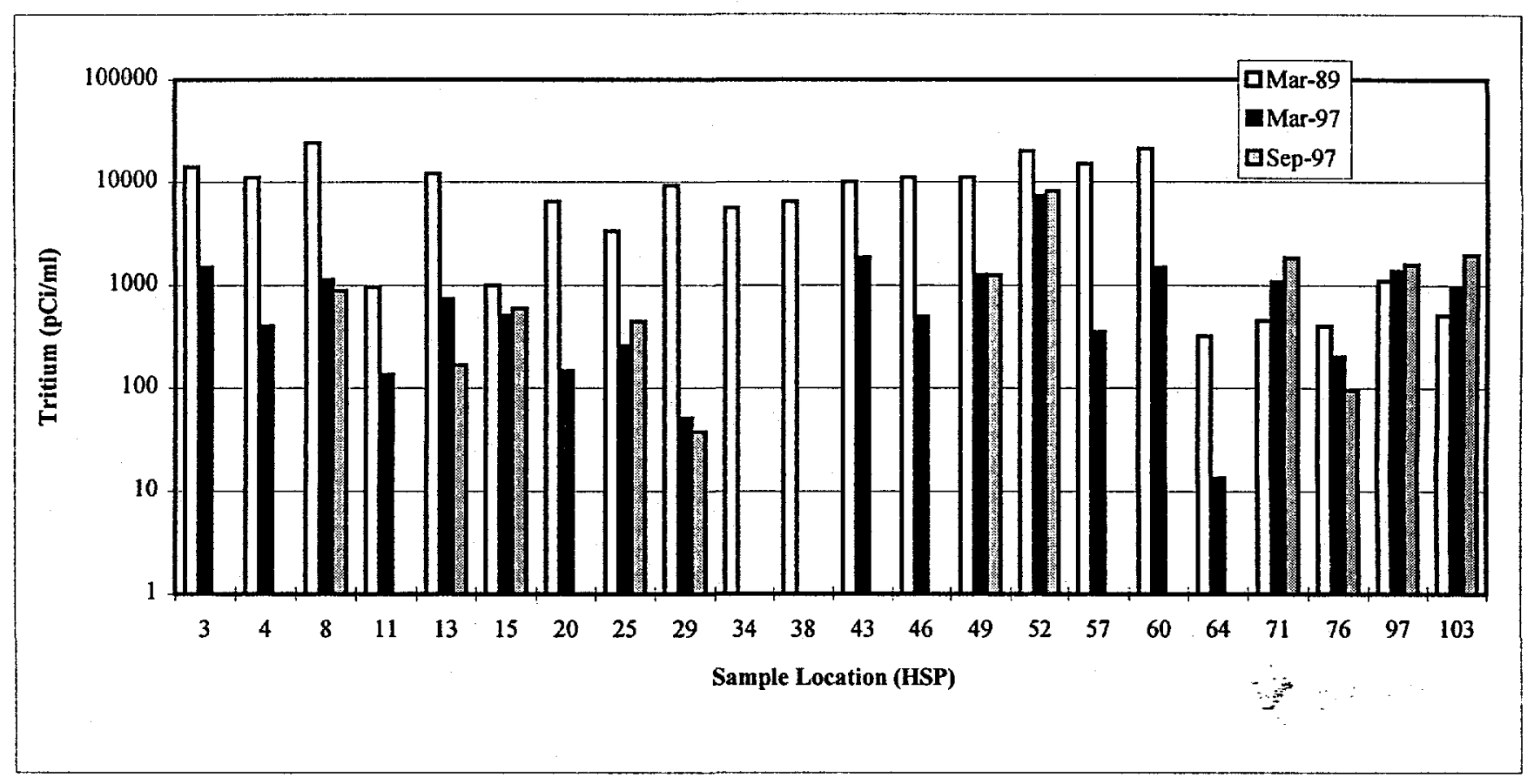

Figure 7. Comparison of Tritium Concentration at H-Area Seepline Locations

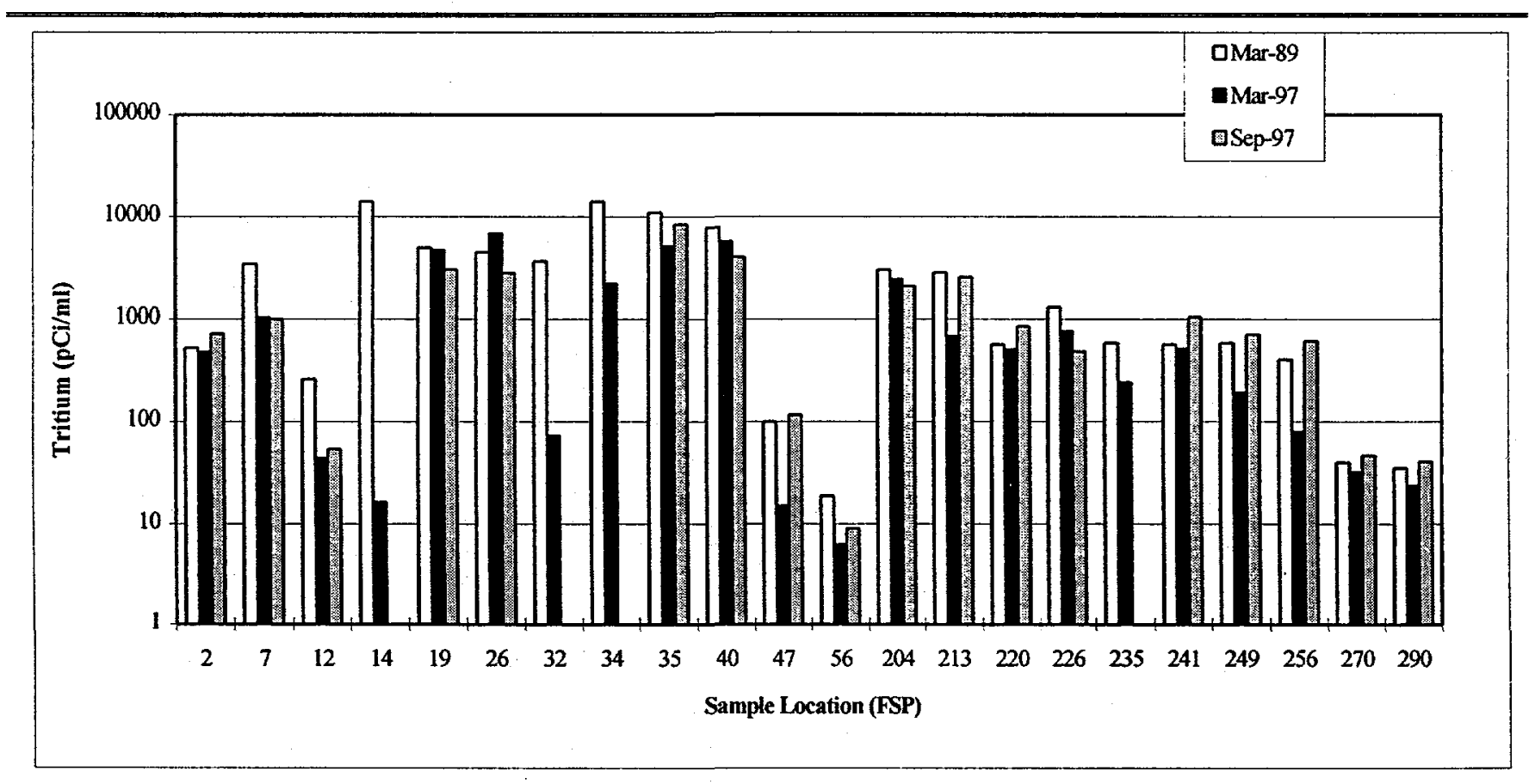

Figure 8. Comparison of Tritium Concentration at F-Area Seepline Locations 


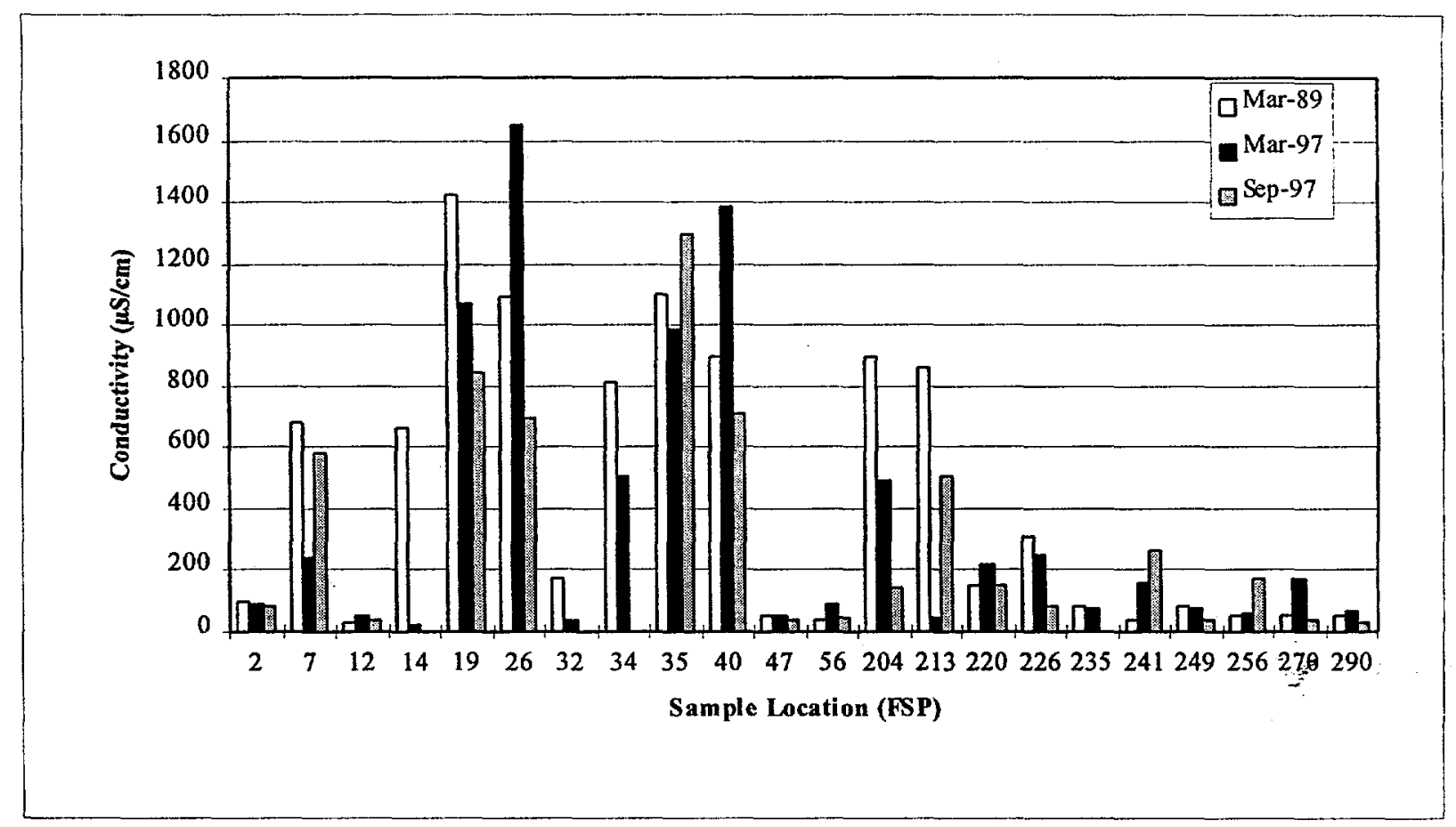

Figure 9. Comparison of Specific Electrical Conductivity at F-Area Seepline Locations

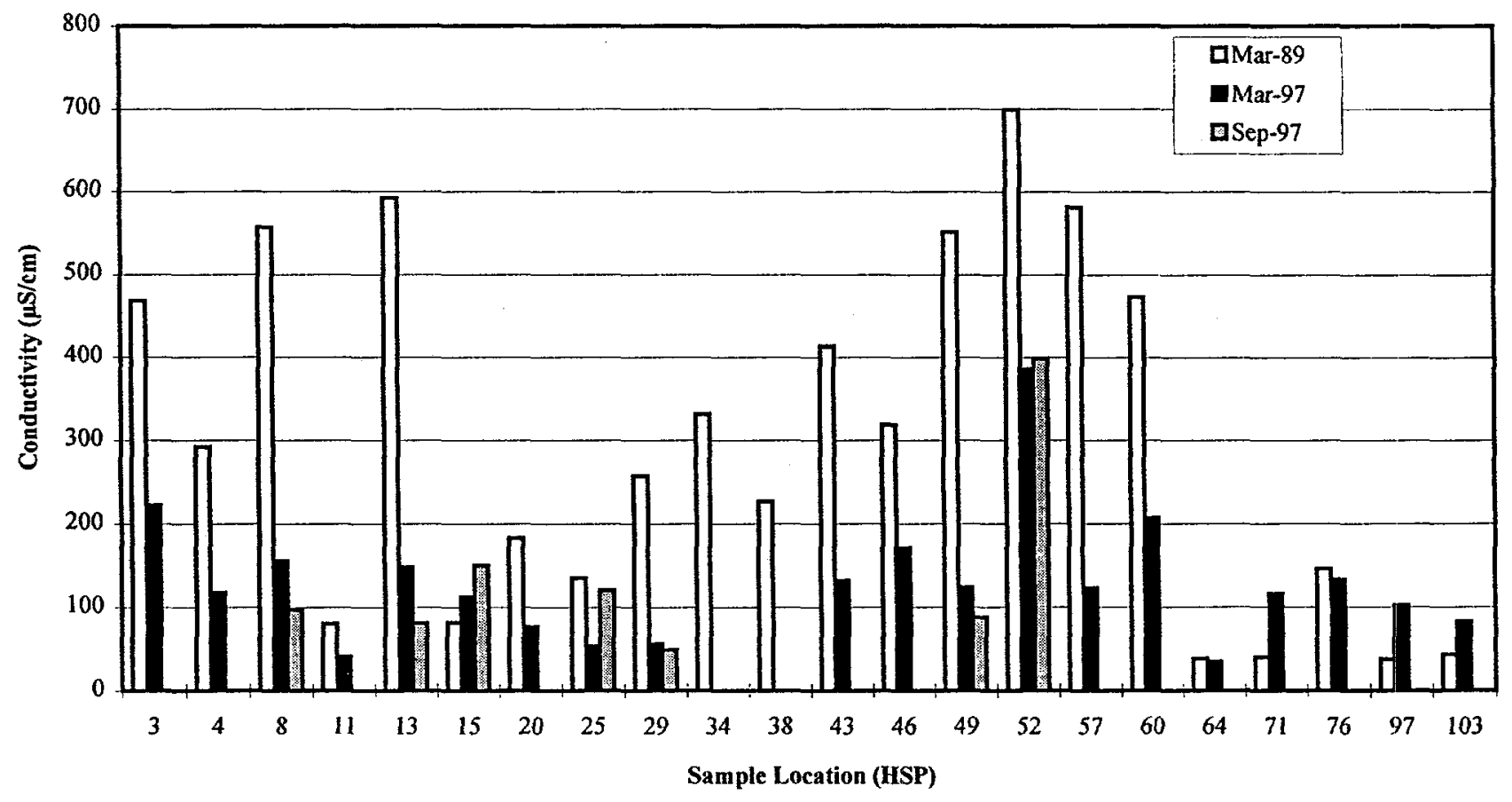

Figure 10. Comparison of Specific Electrical Conductivity at H-Area Seepline Locations. 
Results of the Tritium Survey of Fourmile Branch andits Seeplines in the F and $H$ Areas of SRS: September 1997 and 1989-1997 Summary

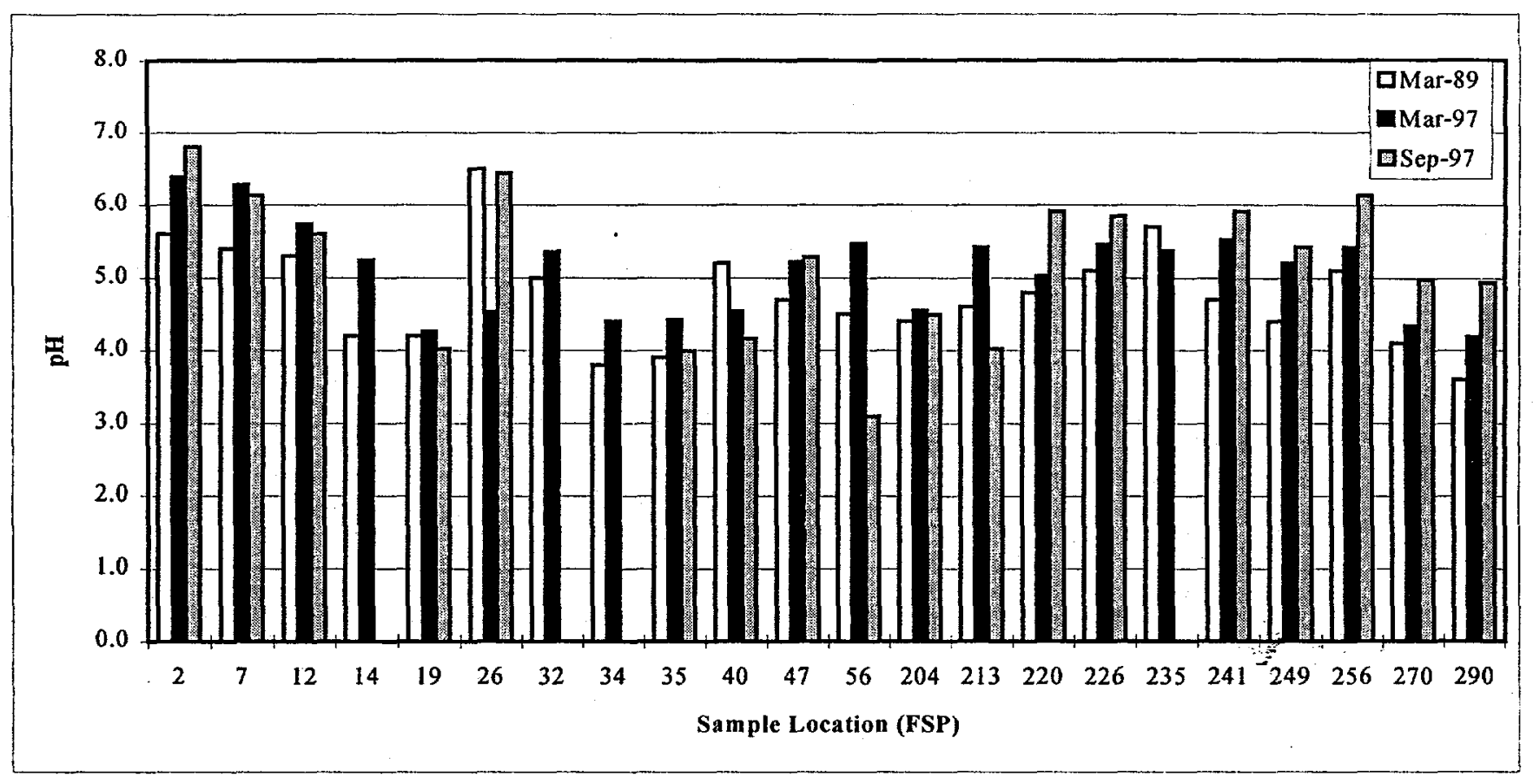

Figure 11. Comparison of $\mathrm{pH}$ at F-Area Seepline Locations.

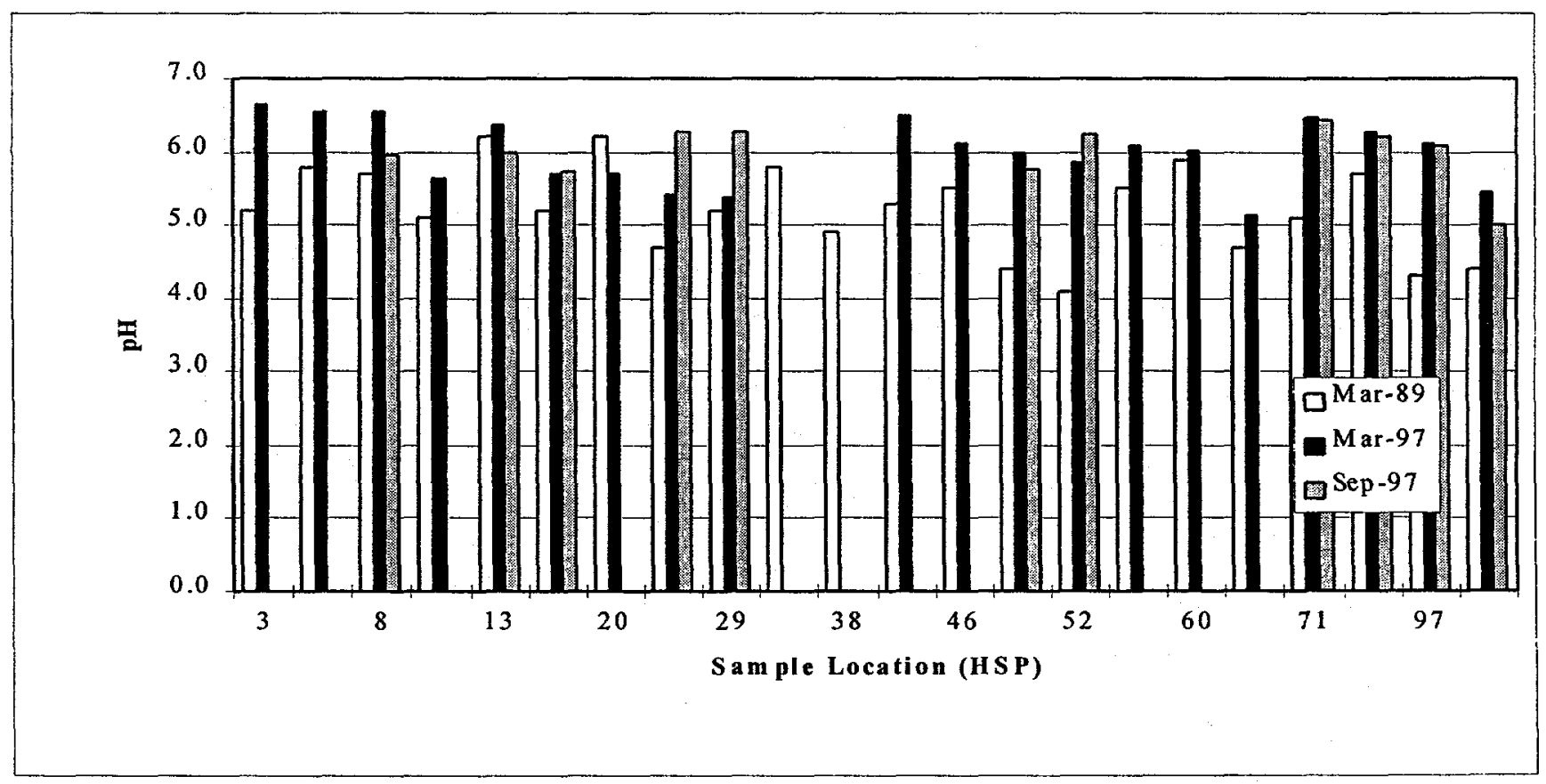

Figure 12. Comparison of $\mathrm{pH}$ at $\mathrm{H}-$ Area Seepline Locations. 


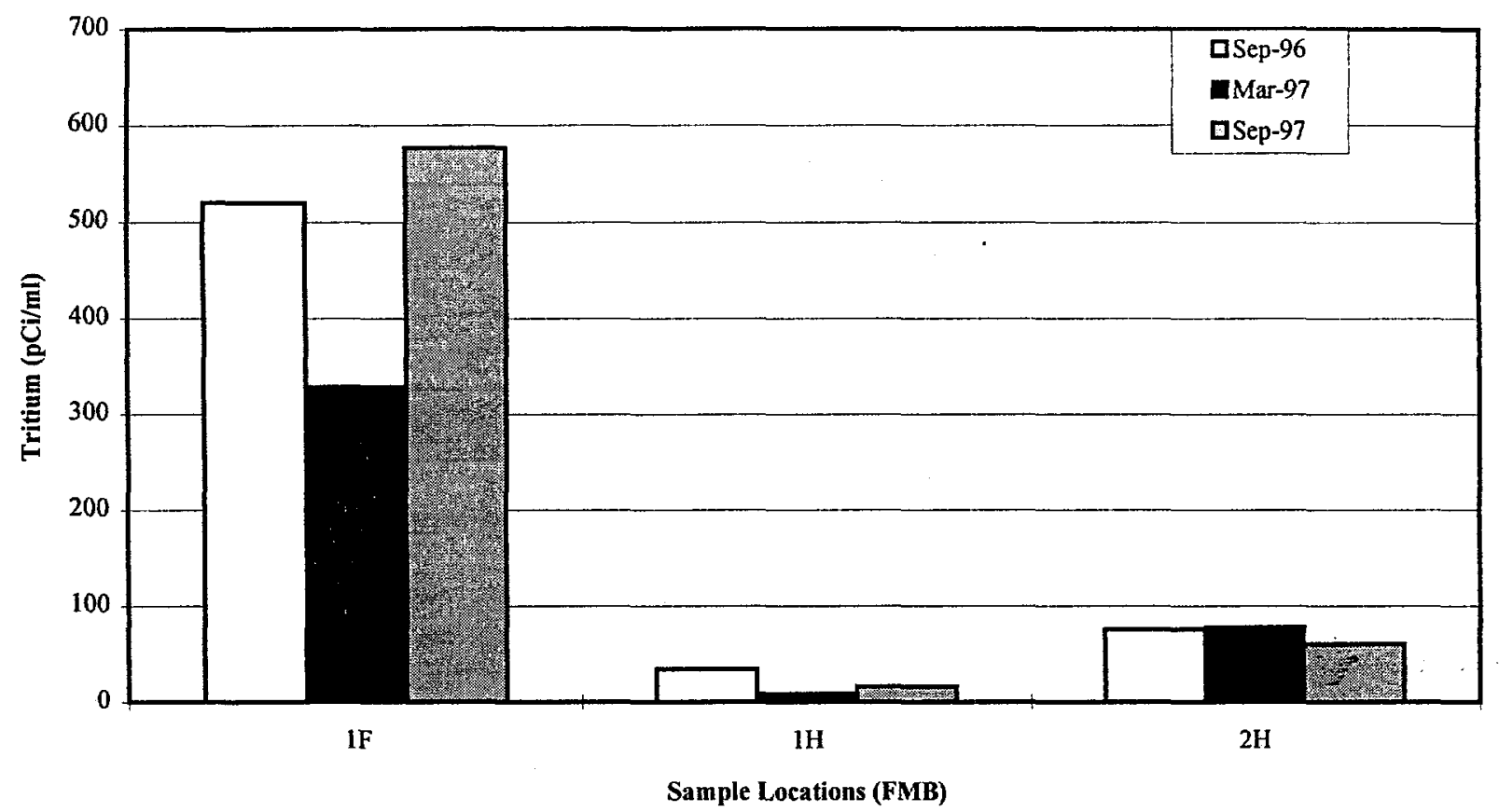

Figure 13. Comparison of Tritium Concentrations at Fourmile Branch Locations.

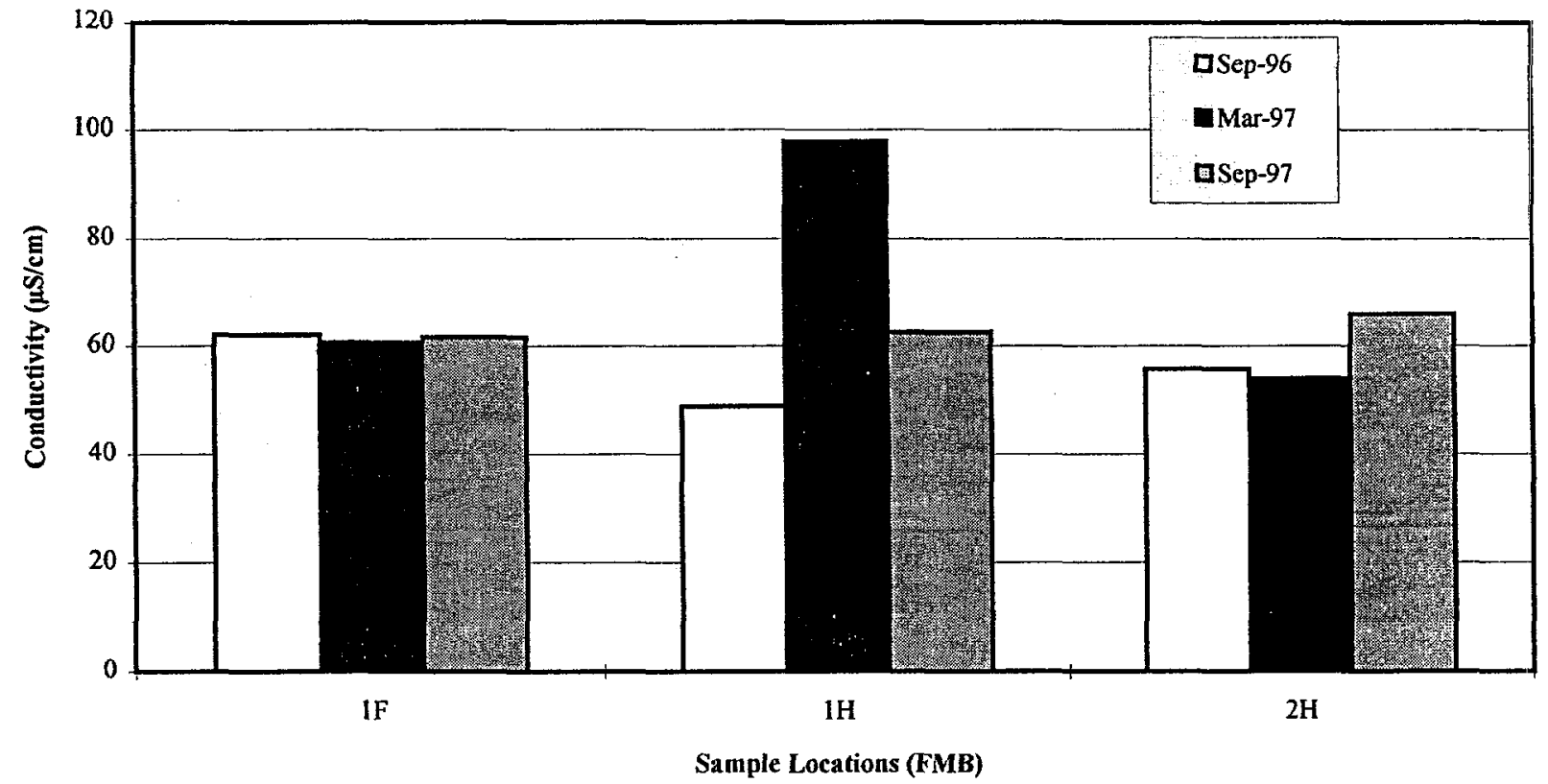

Figure 14. Comparison of Specific Electric Conductivity at Fourmile Branch Locations. 
Results of the Tritium Survey of Fourmile Branch andits Seeplines in the F and $H$ Areas of SRS: September 1997 and 1989-1997 Summary

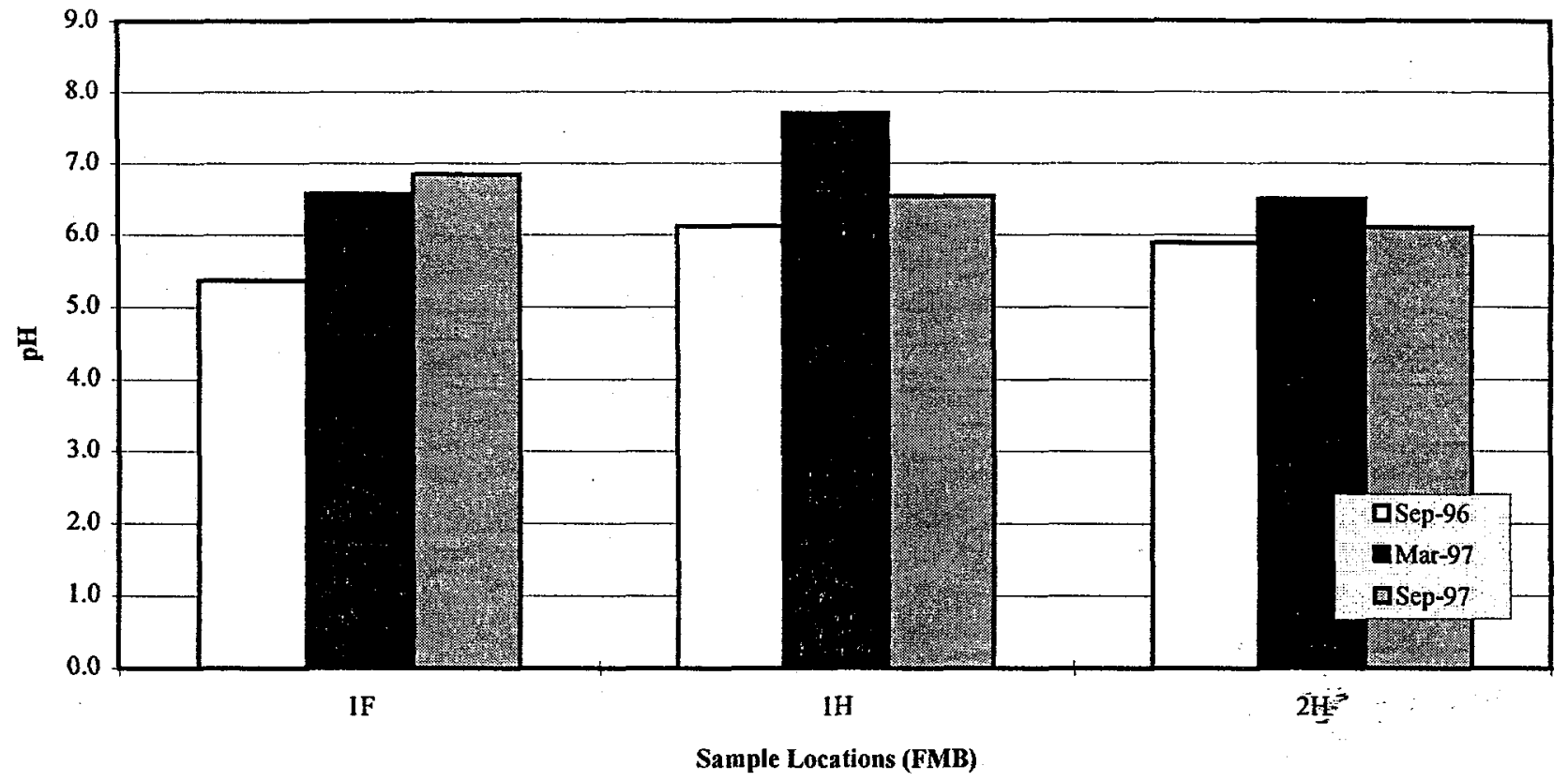

Figure 15. Comparison of $\mathrm{pH}$ at Fourmile Branch Locations.

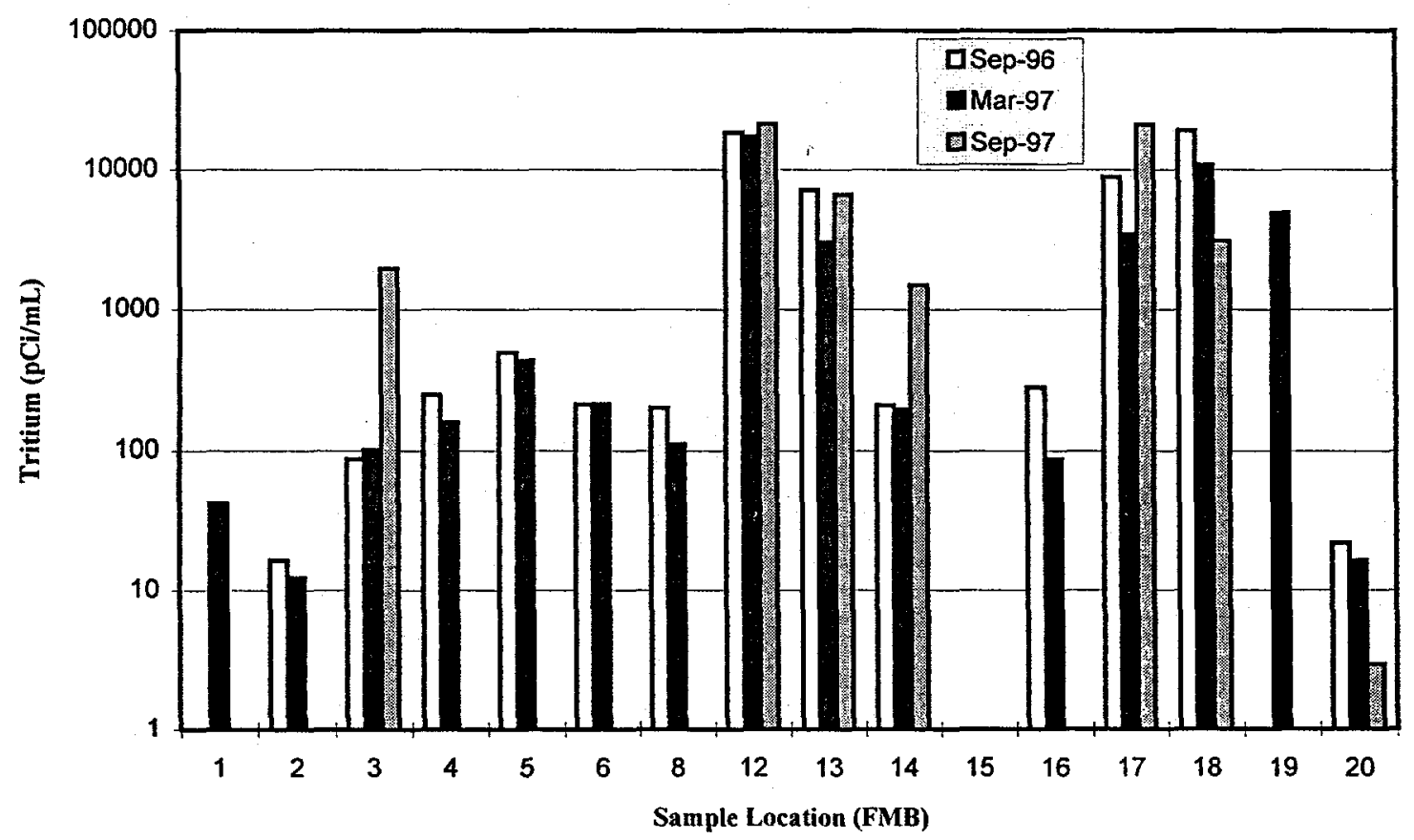

Figure 16. Comparison of Tritium Concentrations at Locations on the Seepline South of 643-E. 


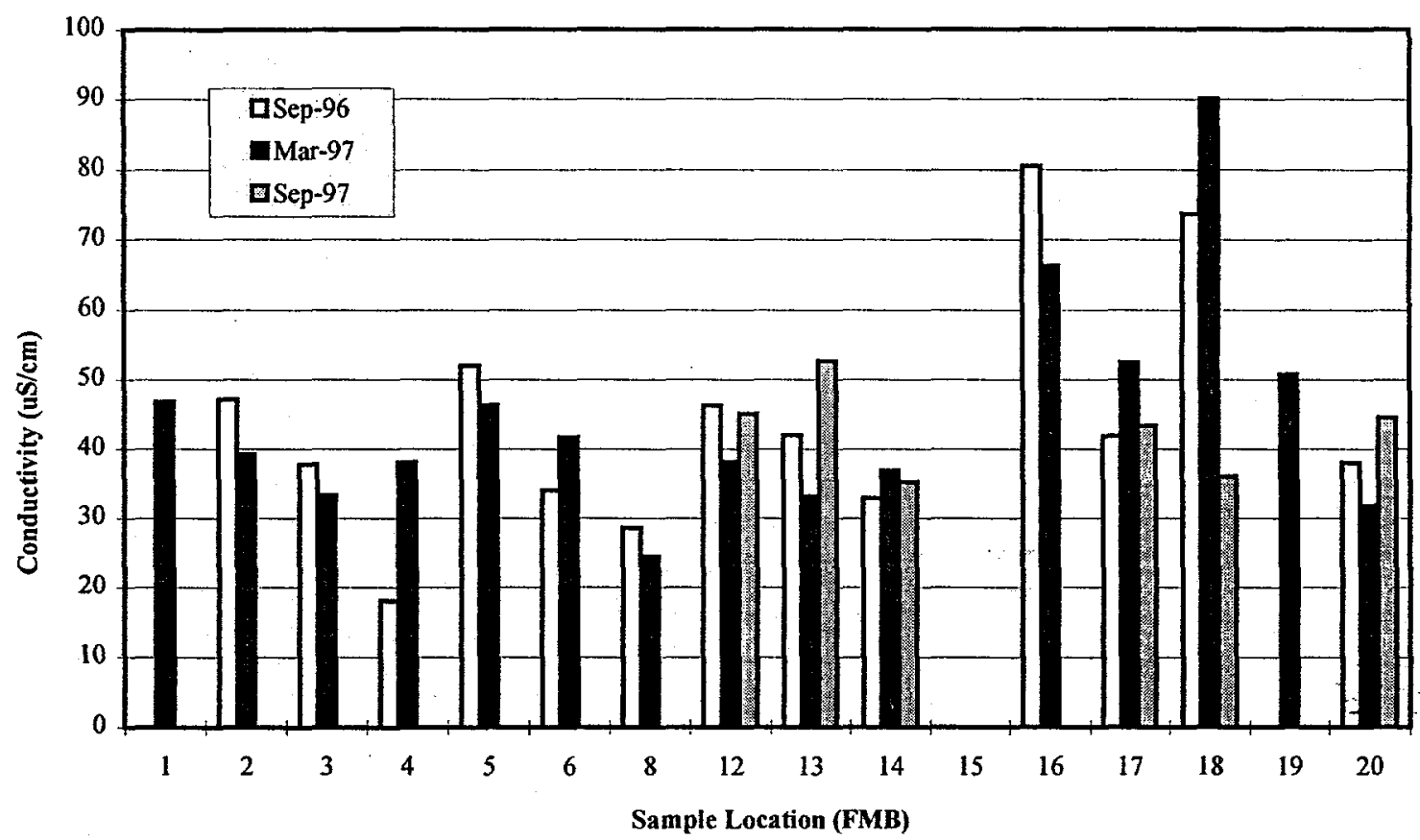

Figure 17. Comparison of Specific Electrical Conductivity at Locations on the Seepline South of 643-E.

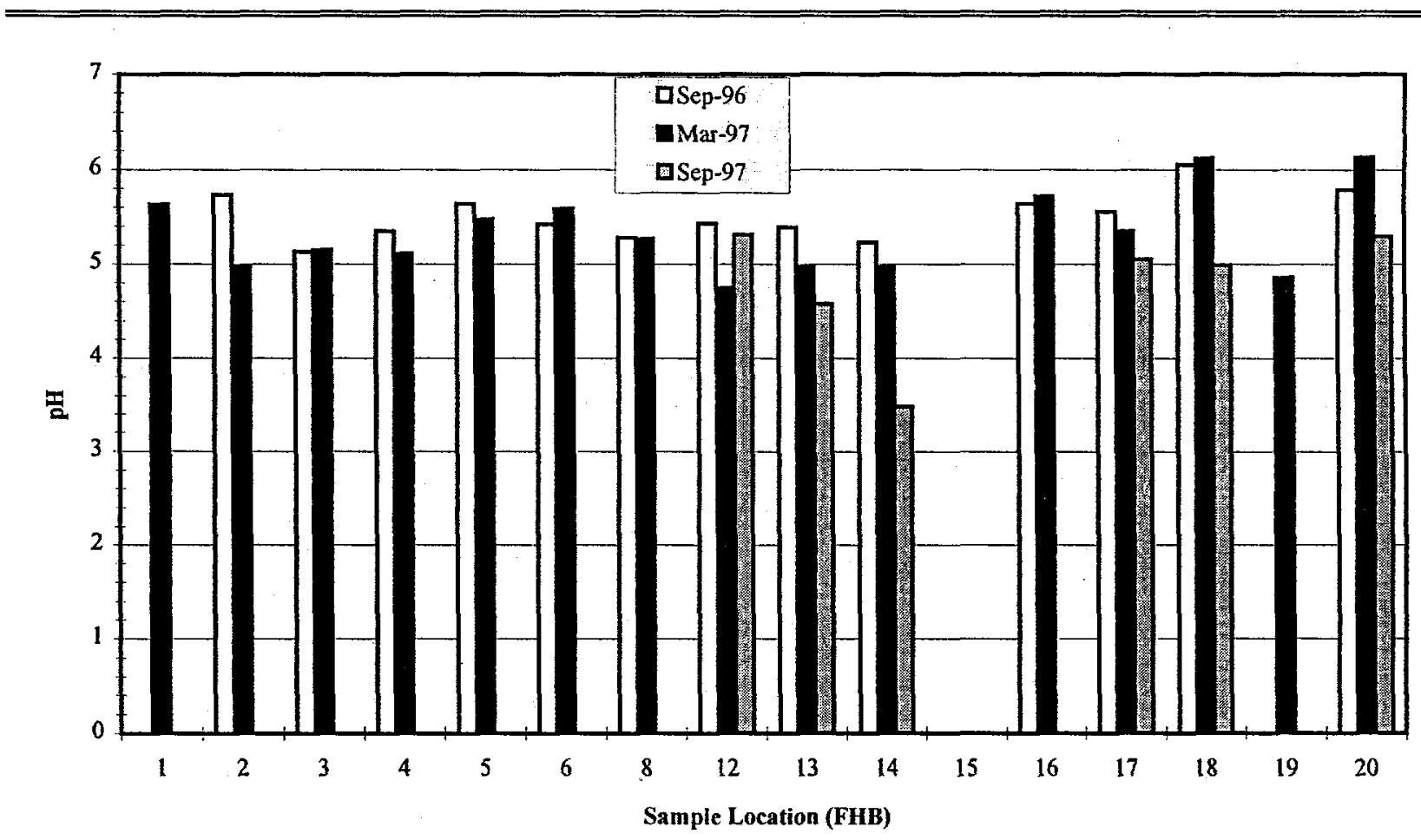

Figure 18. Comparison of $\mathrm{pH}$ at Locations on the Seepline South of 643-E. 


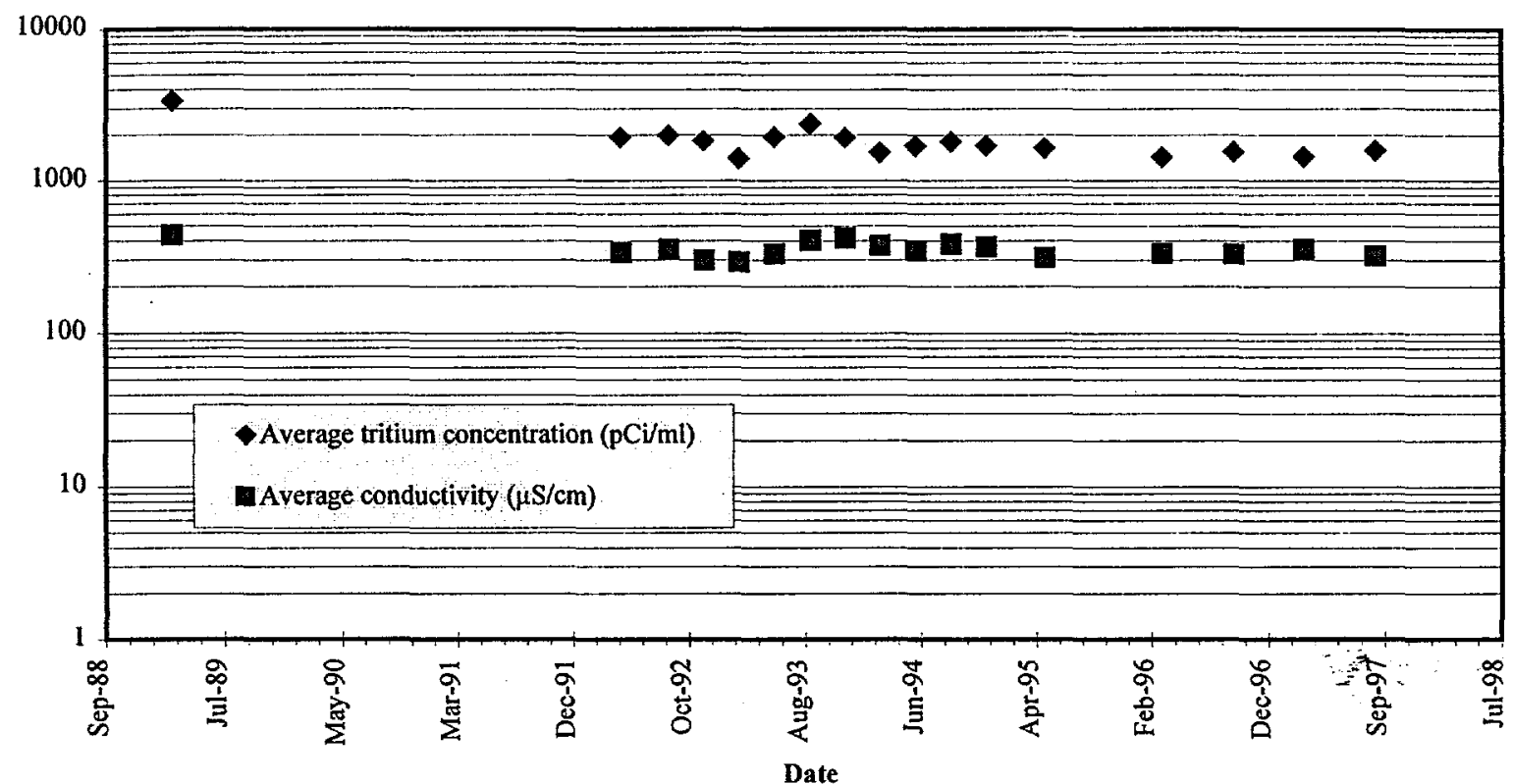

Figure 19. Tritium and Conductivity Trends for F-Area Seepline. Each point represents the mean value of a sampling event.

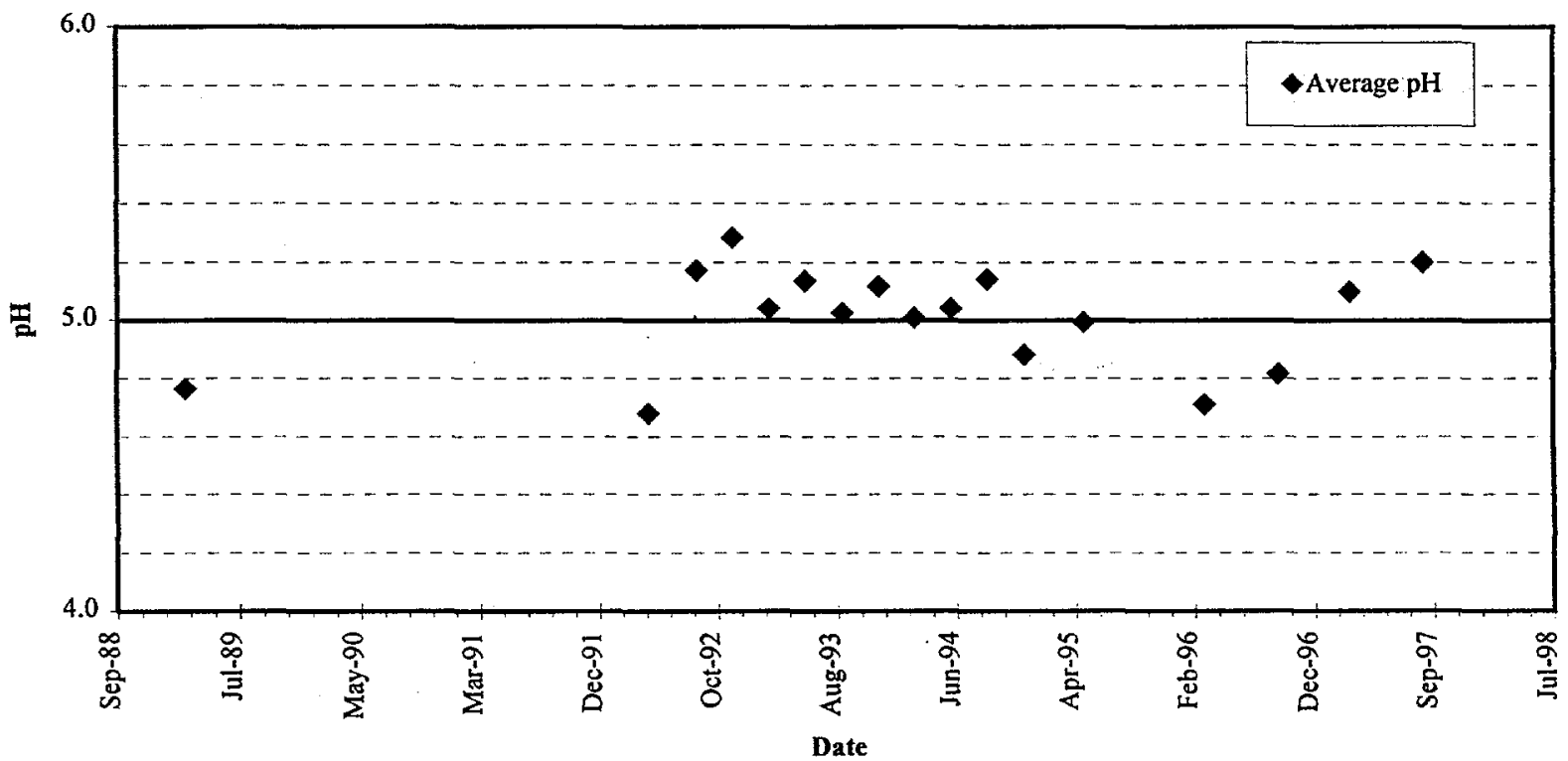

Figure 20. $\mathrm{pH}$ trends for the $\mathrm{F}$-Area Seepline. Each point represents the average value of a sampling event. 
WSRC-TR-98-00365

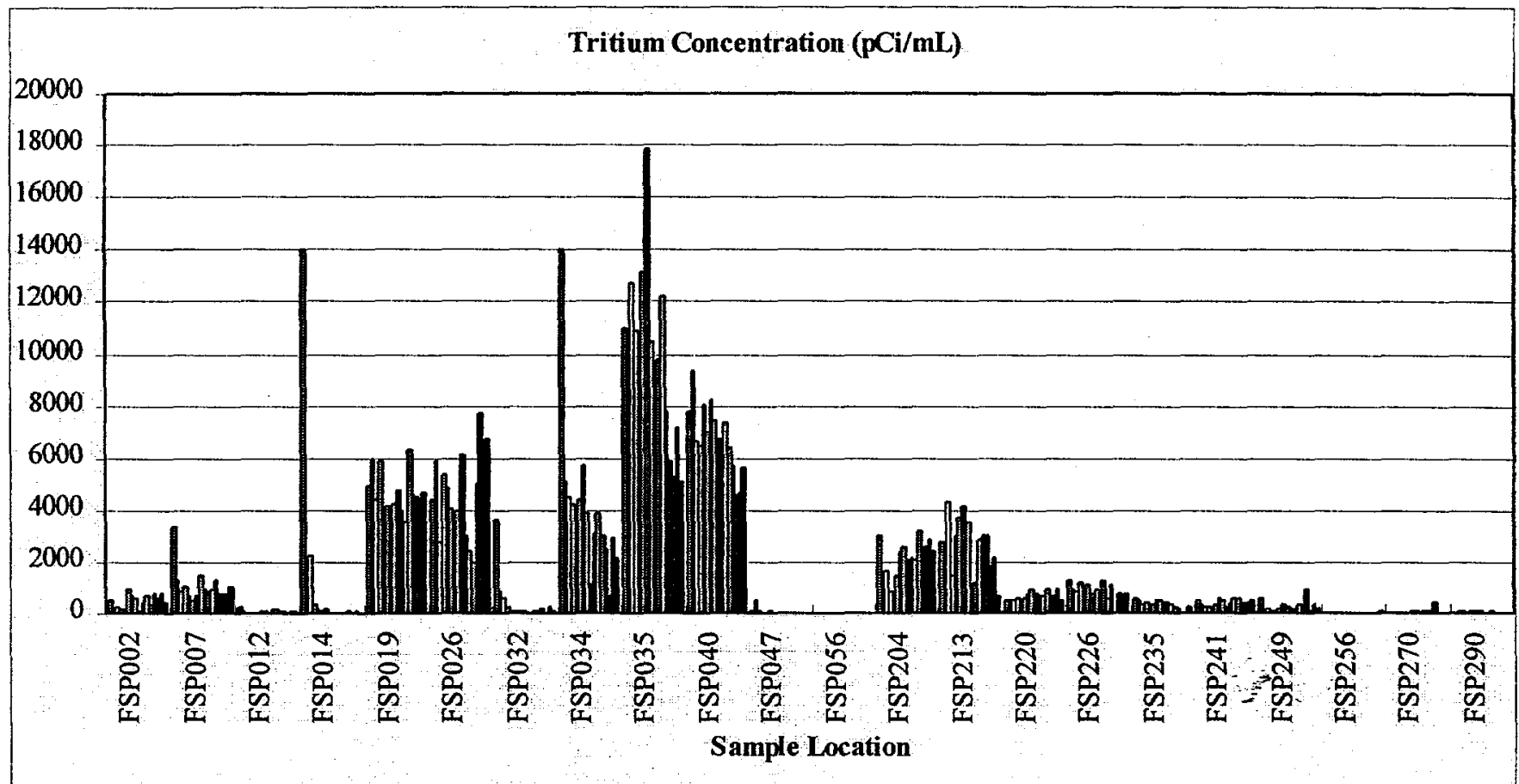

Figure 21. Tritium concentrations for F-Area Seepline (1989-1997)

Plot shows distribution of tritium throughout the entire sampling period.

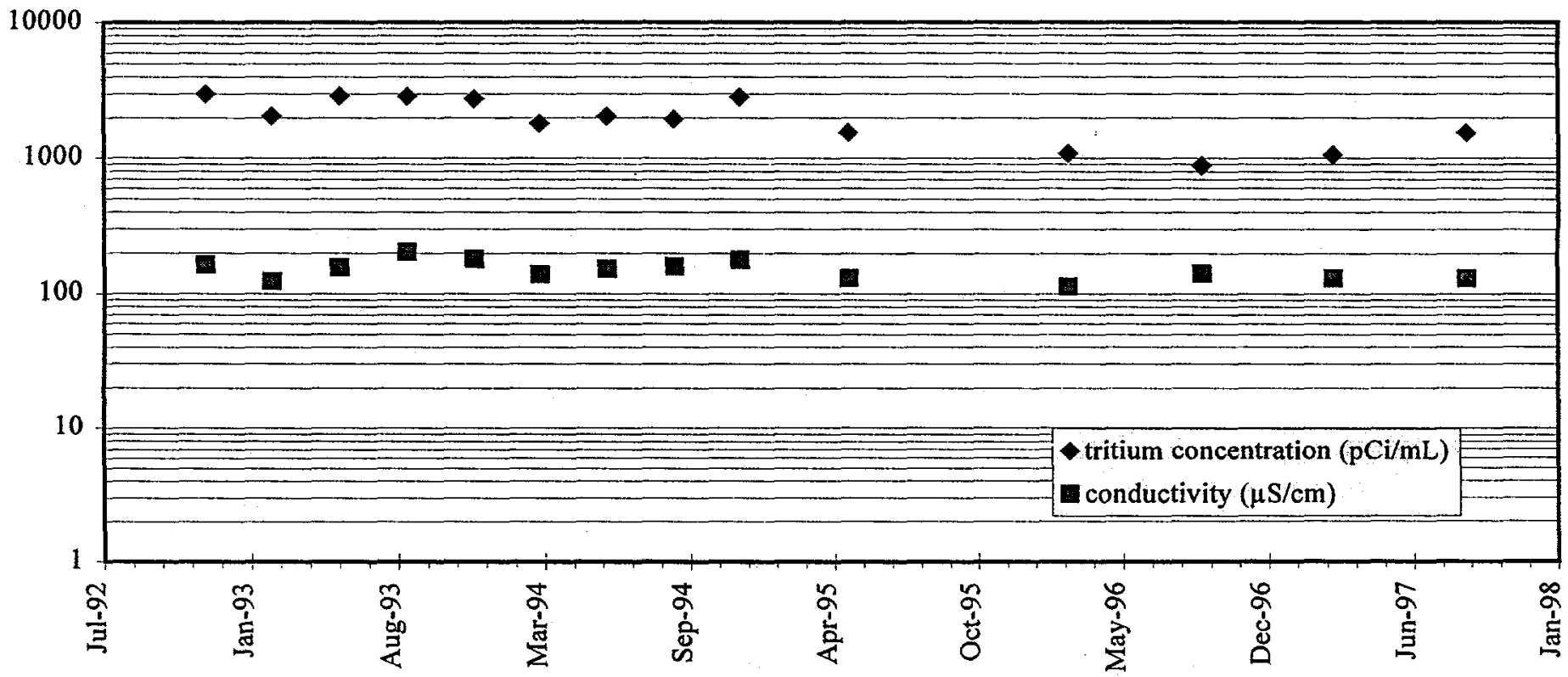

Date

Figure 22. Tritium and conductivity trends for H-Area Seepline. Each point represents the mean value of a sampling event. 


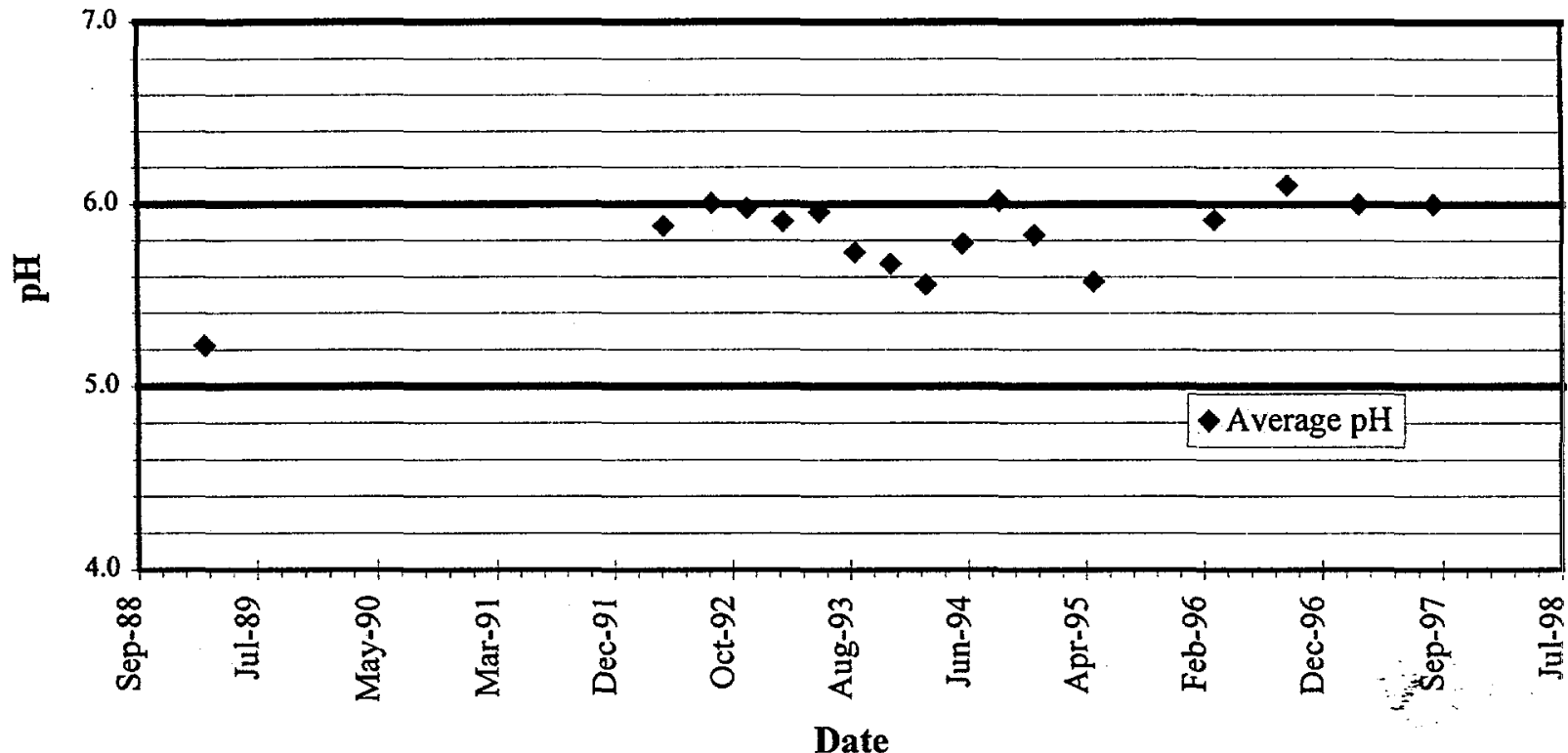

Figure 23. The $\mathrm{pH}$ trends for the H-Area Seepline. Each point represents the average $\mathrm{pH}$ value of a sampling event.

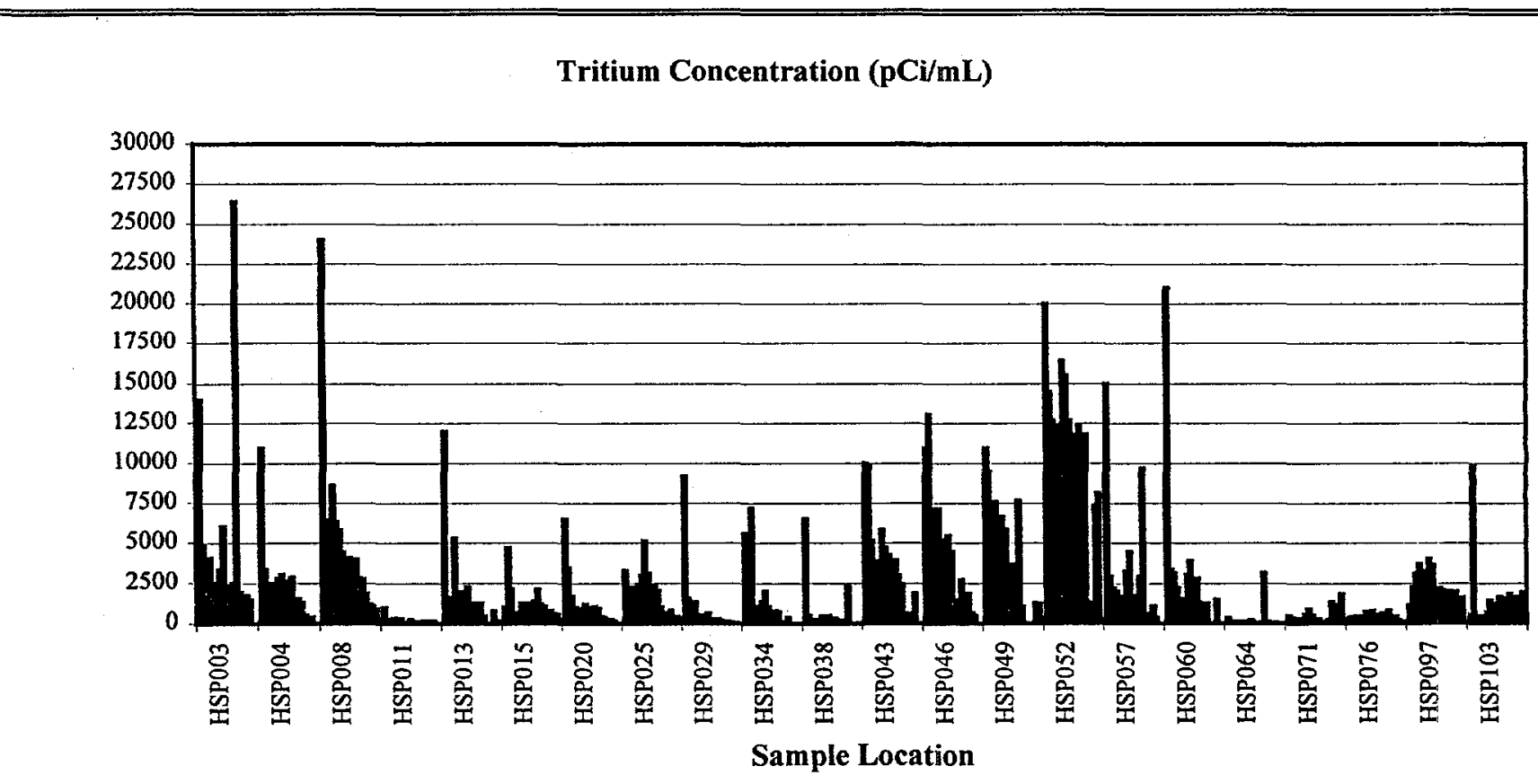

Figure 24. Tritium concentrations at the H-Area Seepline (1989-1997)

Plot shows distribution of tritium throughout the entire sampling period. 


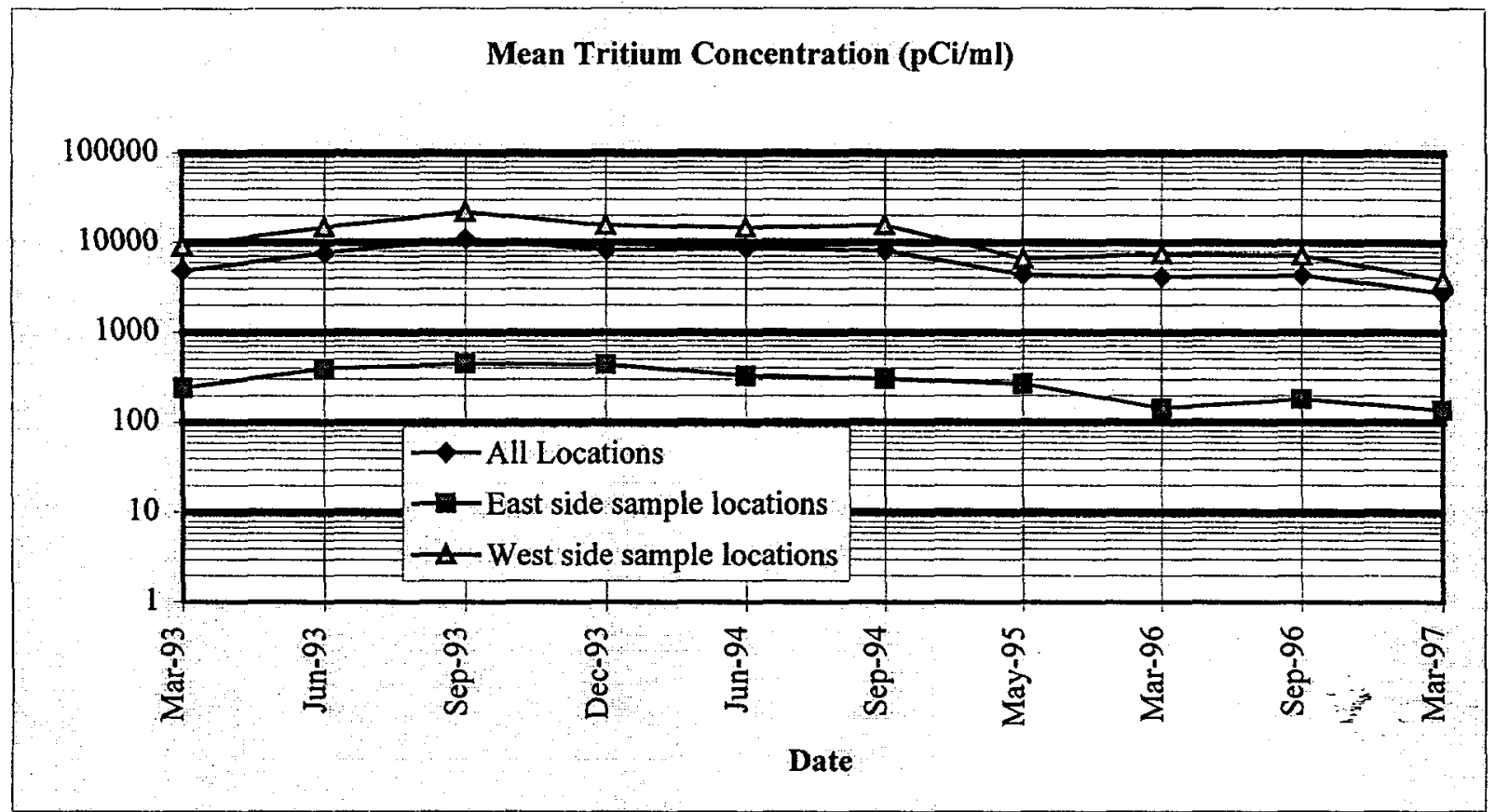

Figure 25. Comparison of tritium concentrations for Seepline below 643-E. Each point represents the mean value of a sampling event. Note: September 1997 value not plotted because of 14 dry locations.

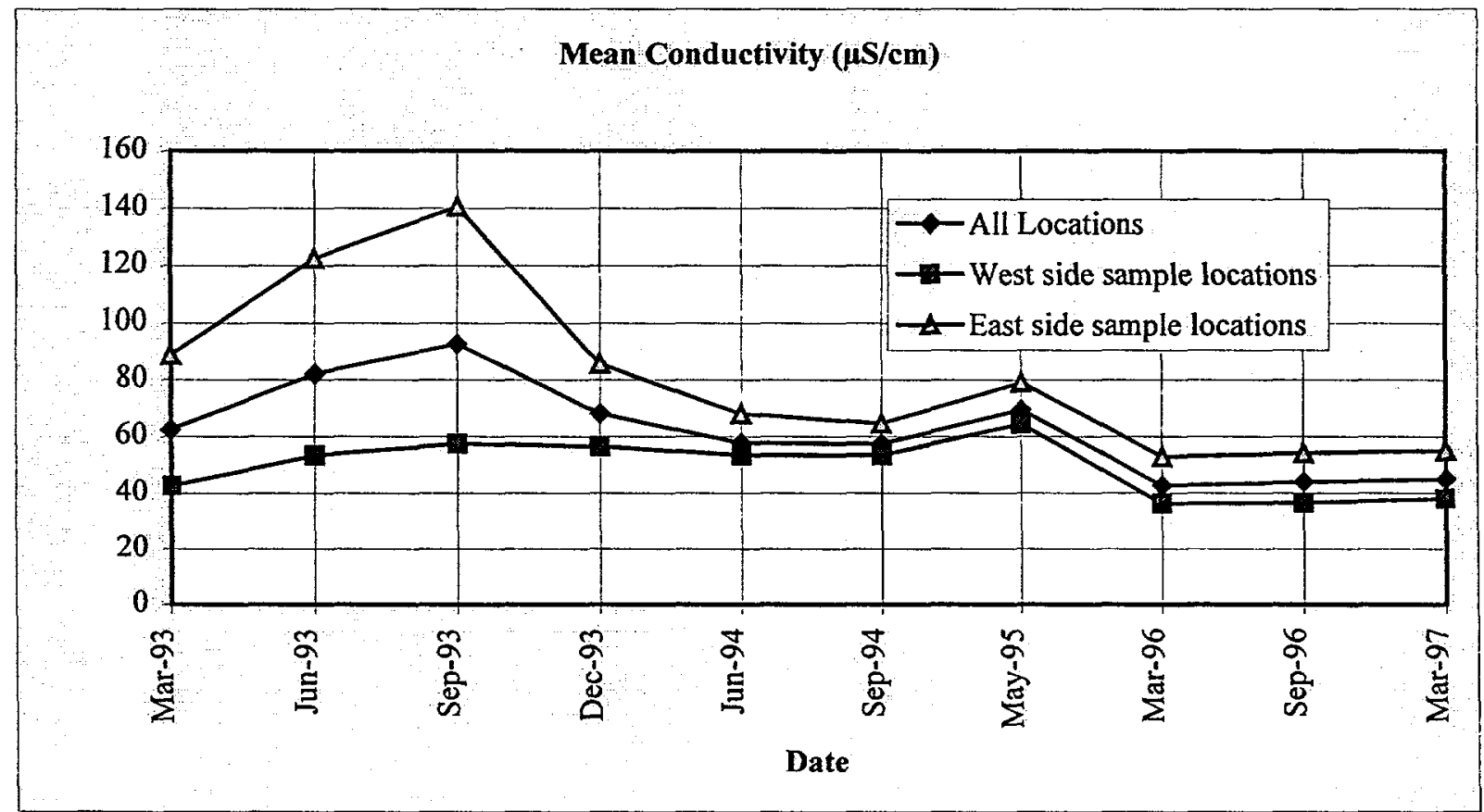

Figure 26. Comparison of conductivity concentrations for the Seepline below 643-E. Each point represents the mean value of a sampling event. Note: September 1997 value not plotted because of 14 dry locations. 

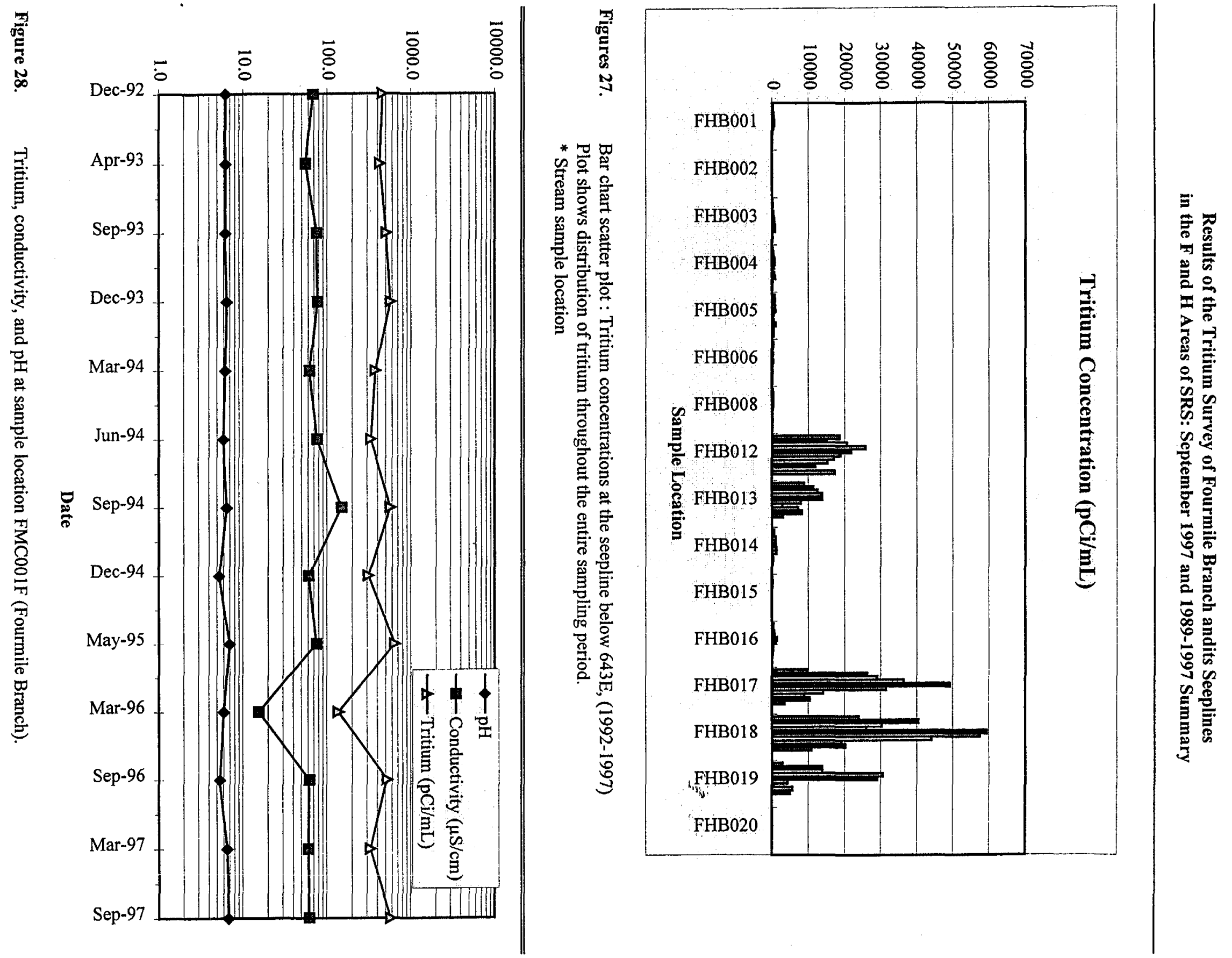


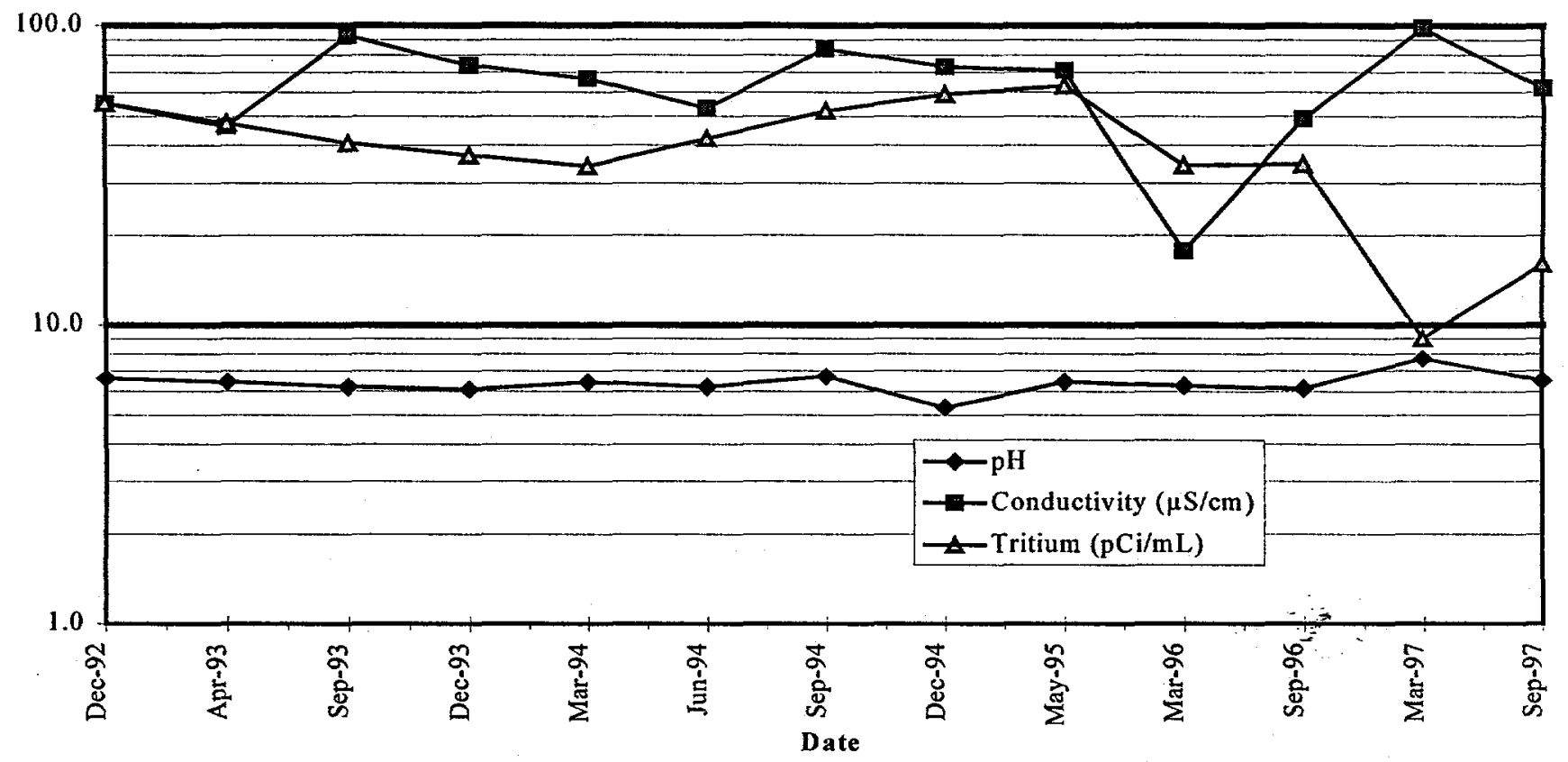

Figure 29. Tritium, conductivity, and pH sample location FMC001H (Fourmile Branch)

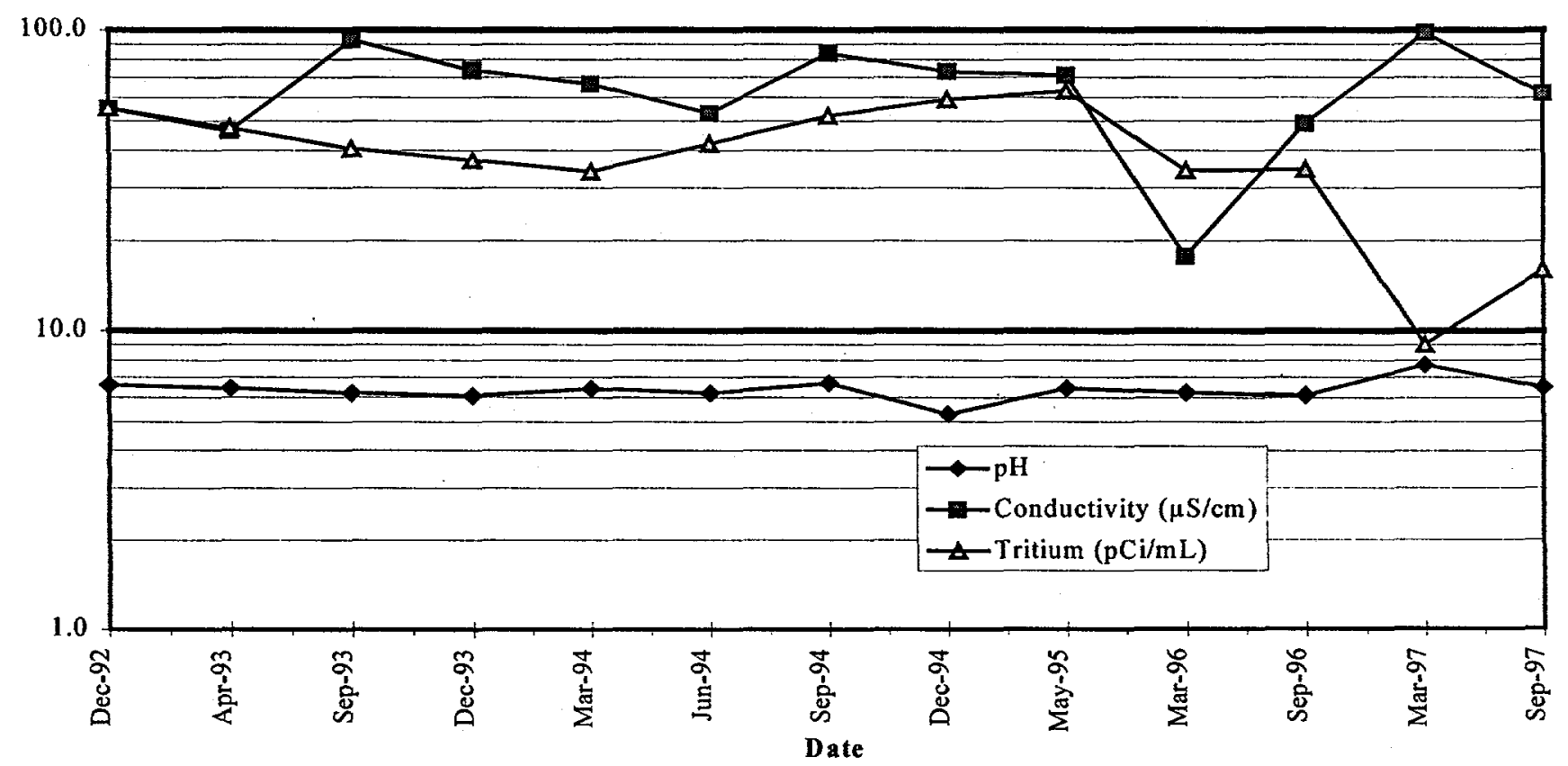

Figure 30. Tritium, conductivity, and $\mathrm{pH}$ at sample location FMC002H (Fourmile Branch). 
Table I. Comparison of 1996/1997 Monthly Rainfall to the Long Term Average Rainfall From the F-Area Weather Station

\begin{tabular}{|c|c|c|c|}
\hline Month & Year & $\begin{array}{c}\text { Rainfall (cm), F-Area Weather Station, } \\
\text { (Sept.1996-Aug.1997) }\end{array}$ & $\begin{array}{c}\text { Longterm Rainfall (cm), F-Area } \\
\text { Weather Station, (1961-1994) }\end{array}$ \\
\hline Sept & 96 & 7.98 & 8.77 \\
\hline Oct & 96 & 5.31 & 7.80 \\
\hline Nov & 96 & 3.71 & 7.12 \\
\hline Dec & 96 & 7.54 & 8.97 \\
\hline Jan & 97 & 10.67 & 11.14 \\
\hline Feb & 97 & 14.12 & 10.74 \\
\hline Mar & 97 & 5.89 & 12.62 \\
\hline April & 97 & 9.86 & 8.01 \\
\hline May & 97 & 6.15 & 9.31 \\
\hline June & 97 & 17.20 & 11.77 \\
\hline July & 97 & 17.83 & 13.97 \\
\hline Aug & 97 & 5.92 & 14.56 \\
\hline
\end{tabular}

Table 2. Comparison of F-Area Seepline Measurements for Tritium, Conductivity, and pH for the March 1989, March 1997, and September 1997 Sampling Events.

\begin{tabular}{|c|c|c|c|c|c|c|c|c|c|c|}
\hline & \multicolumn{3}{|c|}{ Tritium (pCi/ml) } & \multicolumn{2}{c|}{ Conductivity $(\boldsymbol{\mu S} / \mathbf{c m})$} & & pH(-log H) & \\
\hline Location & Mar-89 & Mar-97 & Sep-97 & Mar-89 & Mar-97 & Sep-97 & Mar-89 & Mar-97 & Sep-97 \\
\hline 2 & 520 & 476 & 717 & 95 & 90 & 80 & 5.6 & 6.4 & 6.8 \\
\hline 7 & 3400 & 1040 & 1000 & 681 & 244 & 579 & 5.4 & 6.3 & 6.13 \\
\hline 12 & 260 & 44 & 54 & 30 & 50 & 36 & 5.3 & 5.7 & 5.6 \\
\hline 14 & 14000 & 17 & dry & 666 & 24 & dry & 4.2 & 5.2 & dry \\
\hline 19 & 4900 & 4660 & 3000 & 1424 & 1068 & 846 & 4.2 & 4.3 & 4.02 \\
\hline 26 & 4400 & 6770 & 2750 & 1095 & 1649 & 694 & 6.5 & 4.5 & 6.44 \\
\hline 32 & 3600 & 73 & dry & 174 & 37 & dry & 5.0 & 5.4 & dry \\
\hline 34 & 14000 & 2180 & dry & $\mathbf{8 1 0}$ & 503 & dry & 3.8 & 4.4 & dry \\
\hline 35 & 11000 & 5090 & 8380 & 1100 & 989 & 1297 & 3.9 & 4.4 & 3.99 \\
\hline 40 & 7800 & 5670 & 3970 & 900 & 1382 & 709 & 5.2 & 4.5 & 4.16 \\
\hline 47 & 100 & 15 & 117 & 52 & 54 & 41 & 4.7 & 5.2 & 5.28 \\
\hline 56 & 19 & 6 & 9 & 34 & 88 & 47 & 4.5 & 5.5 & 3.1 \\
\hline 204 & 3000 & 2400 & 2070 & 895 & 487 & 142 & 4.4 & 4.6 & 4.49 \\
\hline 213 & 2800 & 684 & 2530 & 860 & 48 & 502 & 4.6 & 5.4 & 4.02 \\
\hline 220 & 560 & 505 & 847 & 147 & 220 & 153 & 4.8 & 5.0 & 5.91 \\
\hline 226 & 1300 & 758 & 476 & 306 & 251 & 81 & 5.1 & 5.5 & 5.85 \\
\hline 235 & 580 & 242 & dry & 84 & 76 & dry & 5.7 & 5.4 & dry \\
\hline 241 & 560 & 515 & 1050 & 36 & 155 & 266 & 4.7 & 5.5 & 5.91 \\
\hline 249 & 580 & 193 & 702 & 84 & 78 & 39 & 4.4 & 5.2 & 5.42 \\
\hline 256 & 400 & 80 & 608 & 56 & 58 & 174 & 5.1 & 5.4 & 6.13 \\
\hline 270 & 40 & 32 & 47 & 50 & 170 & 40 & 4.1 & 4.3 & 4.98 \\
\hline 290 & 35 & 24 & 41 & 49 & 65 & 32 & 3.6 & 4.2 & 4.94 \\
\hline
\end{tabular}


Table 3. Comparison of H-Area Seepline Measurements for Tritium, Conductivity, and pH for the March 1989, March 1997, and September 1997 Sampling Events.

\begin{tabular}{|c|c|c|c|c|c|c|c|c|c|}
\hline & \multicolumn{3}{|c|}{ Tritium (pCi/ml) } & \multicolumn{3}{|c|}{ Conductivity $(\mu \mathrm{S} / \mathrm{cm}) @ 25 \operatorname{deg} \mathrm{C}$} & \multicolumn{3}{|c|}{ pH (-log H } \\
\hline Location & Mar-89 & Mar-97 & Sep-97 & Mar-89 & Mar-97| & Sep-97 & Mar-89 & Mar-97 & Sep-97 \\
\hline$\overline{3}$ & 14000 & 1480 & dry & 468 & 223 & dry & 5.2 & 6.6 & dry \\
\hline 4 & 11000 & 398 & dry & 292 & 117 & dry & 5.8 & 6.6 & dry \\
\hline 8 & 24000 & 1130 & 884 & 556 & 156 & 97 & 5.7 & 6.6 & 5.96 \\
\hline 11 & 960 & 135 & dry & 80 & 41 & dry & 5.1 & 5.7 & dry \\
\hline 13 & 12000 & 735 & 168 & 592 & 148 & 81 & 6.2 & 6.4 & 5.98 \\
\hline 15 & 1000 & 504 & 593 & 82 & 112 & 151 & 5.2 & 5.7 & 5.73 \\
\hline 20 & 6500 & 147 & dry & 183 & 77 & dry & 6.2 & 5.7 & dry \\
\hline 25 & 3300 & 258 & 441 & 135 & 53 & 120 & 4.7 & 5.4 & 6.27 \\
\hline 29 & 9200 & 51.2 & 38 & 257 & 56 & 49 & 5.2 & 5.4 & 6.27 \\
\hline 34 & 5600 & dry & dry & 331 & dry & dry & 5.8 & dry & dry \\
\hline 38 & $6 \overline{600}$ & dry & dry & 227 & dry & dry & 4.9 & dry & dry \\
\hline 43 & 10000 & 1840 & dry & 413 & 132 & dry & 5.3 & 6.5 & dry \\
\hline 46 & 11000 & 494 & dry & 318 & 171 & dry & 5.5 & 6.1 & dry \\
\hline 49 & 11000 & 1250 & 1240 & 551 & 124 & 87 & 4.4 & 6.0 & 5.75 \\
\hline 52 & 20000 & 7320 & 8120 & 699 & 385 & 399 & 4.1 & 5.9 & 6.24 \\
\hline 57 & 15000 & 354 & dry & 581 & 122 & dry & 5.5 & 6.1 & dry \\
\hline 60 & 21000 & 1470 & dry & 473 & 207 & dry & 5.9 & 6.0 & dry \\
\hline 64 & 320 & 13.6 & dry & 38 & 35 & dry & 4.7 & 5.1 & dry \\
\hline 71 & 450 & 1070 & 1830 & 40 & 115 & 160 & 5.1 & 6.5 & 6.42 \\
\hline 76 & 400 & 202 & 96 & 146 & 133 & 70 & 5.7 & 6.3 & 6.2 \\
\hline 97 & 1100 & 1370 & 1580 & 37 & 102 & 146 & 4.3 & 6.1 & 6.09 \\
\hline 103 & 510 & 927 & 1940 & 43 & 83 & 125 & 4.4 & 5.5 & 5.01 \\
\hline
\end{tabular}

Table 4. Comparison Measurements for Tritium, Conductivity, and pH in Fourmile Branch for the March 1996, March 1997, and September 1997 Sampling Events.

\begin{tabular}{|c|c|c|c|c|c|c|c|c|c|}
\hline & \multicolumn{3}{|c|}{ Tritium (pCi/ml) } & \multicolumn{3}{c|}{ Conductivity $(\mu \mathrm{S} / \mathrm{cm})$} & \multicolumn{3}{c|}{ pH (-log H) } \\
\hline Location & Sep-96 & Mar-97 & Sep-97 & Sep-96 & Mar-97 & Sep-97 & Sep-96 & Mar-97 & Sep-97 \\
\hline 1F & 520 & 329 & 577 & 62 & 61 & 62 & 5.4 & 6.6 & 6.8 \\
\hline 1H & 35 & 9 & 16 & 49 & 98 & 62 & 6.1 & 7.7 & 6.5 \\
\hline 2H & 76 & 78 & 61 & 56 & 54 & 66 & 5.9 & 6.5 & 6.1 \\
\hline
\end{tabular}


Table 5. Comparison of 643-E Seepline Measurements for Tritium, Conductivity, and pH for the March 1996, March 1997, and September 1997 Sampling Events. (Note: Location 12 is a stream sample location.)

\begin{tabular}{|c|c|c|c|c|c|c|c|c|c|}
\hline & \multicolumn{3}{|c|}{ Tritium (pCi/ml) } & \multicolumn{3}{|c|}{ Conductivity $(\mu \mathrm{S} / \mathrm{cm})$} & \multicolumn{3}{|c|}{$|\mathrm{pH}(-\log \mathrm{H})|$} \\
\hline Location & Sep-96 & Mar-97 & Sep-97 & Sep-96 & Mar-97 & Sep-97 & Sep-96 & Mar-97 & Sep-97 \\
\hline 1 & dry & 42 & dry & dry & 47 & dry & dry & 5.6 & dry \\
\hline 2 & 16 & 12 & dry & 47 & 39 & dry & 5.7 & 5.0 & dry \\
\hline 3 & 87 & 101 & 1960 & 38 & 33 & na & 5.1 & 5.2 & na \\
\hline 4 & 247 & 158 & dry & 18 & 38 & dry & 5.4 & 5.1 & dry \\
\hline 5 & 496 & 435 & dry & 52 & 46 & dry & 5.6 & 5.5 & dry \\
\hline 6 & 211 & 213 & dry & 34 & 42 & dry & 5.4 & 5.6 & dry \\
\hline 8 & 200 & 111 & dry & 29 & 24 & dry & 5.3 & 5.3 & dry \\
\hline 12 & 18500 & 17300 & 21300 & 46 & 38 & 45 & 5.4 & 4.8 & 5.31 \\
\hline 13 & 7190 & 3050 & 6660 & 42 & 33 & 53 & 5.4 & 5.0 & 4.58 \\
\hline 14 & 209 & 195 & 1500 & 33 & 37 & 35 & 5.2 & 5.0 & 3.48 \\
\hline 15 & dry & dry & dry & dry & dry & dry & dry & dry & dry \\
\hline 16 & 278 & 87 & dry & 80 & 66 & dry & 5.6 & 5.7 & dry \\
\hline 17 & 8830 & 3470 & 21100 & 42 & 53 & 43 & 5.6 & 5.4 & 5.05 \\
\hline 18 & 19100 & 10800 & 3100 & 74 & 90 & 36 & 6.1 & 6.1 & 4.99 \\
\hline 19 & dry & 4960 & dry & dry & 51 & dry & dry & 4.9 & dry \\
\hline 20 & 22 & 16 & 3 & 38 & 32 & 45 & 5.8 & 6.1 & 5.29 \\
\hline
\end{tabular}

Table 6.

Average Tritium, Conductivity, and $\mathrm{pH}$ values for $\mathrm{F}$ and $\mathrm{H}$ Area Seeplines

(March 1989-September 1997).

\begin{tabular}{|c|c|c|c|c|c|c|}
\hline \multirow[b]{2}{*}{$\begin{array}{c}\text { Sampling Event } \\
\text { Date }\end{array}$} & \multicolumn{3}{|c|}{ F Area Seepline-Average Values } & \multicolumn{3}{|c|}{ H Area Seepline-Average Values } \\
\hline & $\begin{array}{c}\text { tritium } \\
(p C i / m l)\end{array}$ & $\begin{array}{c}\text { Conductivity } \\
(\mu \mathrm{S} / \mathrm{cm})\end{array}$ & $p H$ & $\begin{array}{c}\text { tritium } \\
(p C i / m l)\end{array}$ & $\begin{array}{c}\text { Conductivity } \\
(\mu S / \mathrm{cm})\end{array}$ & $p H$ \\
\hline Mar-89 & 3357 & 438 & 4.8 & 8402 & 297 & 5.2 \\
\hline May-92 & 1934 & $33 \overline{5}$ & 4.7 & 4131 & 183 & 5.9 \\
\hline Sep-92 & 1990 & 352 & 5.2 & 2904 & 182 & 6.0 \\
\hline Dec-92 & 1823 & 300 & 5.3 & 3001 & 165 & 6.0 \\
\hline Mar-93 & 1398 & 293 & 5.0 & 2063 & 124 & 5.9 \\
\hline Jun-93 & 1936 & 330 & 5.1 & 2885 & 157 & 6.0 \\
\hline Sep-93 & 2384 & 404 & 5.0 & 2876 & 205 & 5.7 \\
\hline Dec-93 & 1920 & 415 & 5.1 & 2749 & 181 & 5.7 \\
\hline Mar-94 & 1525 & 371 & 5.0 & 1818 & 140 & 5.6 \\
\hline Jun-94 & 1688 & 344 & 5.0 & 2053 & $1 \overline{53}$ & 5.8 \\
\hline Sep-94 & 1806 & 381 & 5.1 & 1953 & 159 & 6.0 \\
\hline Dec-94 & 1698 & 366 & 4.9 & 2836 & 179 & 5.8 \\
\hline May-95 & 1634 & 311 & 5.0 & 1547 & 131 & 5.6 \\
\hline Mar-96 & 1424 & 331 & 4.7 & 1082 & 113 & 5.9 \\
\hline Sep-96 & 1545 & 328 & 4.8 & 880 & 142 & 6.1 \\
\hline Mar-97 & 1431 & 354 & 5.1 & 1057 & 130 & 6.0 \\
\hline Sep-97 & 1576 & 320 & 5.2 & 1539 & 130 & 6.0 \\
\hline
\end{tabular}


Table 7. Average Tritium and Conductivity, values for Seepline below 643-E.

\begin{tabular}{|c|c|c|c|c|c|c|}
\hline $\begin{array}{l}\text { Sampling } \\
\text { Event Date }\end{array}$ & $\begin{array}{l}\text { Tritium (all) } \\
(\mathrm{pCi} / \mathrm{ml})\end{array}$ & $\left|\begin{array}{c}\text { Tritium (East) } \\
(\mathrm{pCi} / \mathrm{ml})\end{array}\right|$ & $\begin{array}{c}\text { Tritium (West) } \\
(\mathrm{pCi} / \mathrm{ml})\end{array}$ & $\begin{array}{l}\text { Conductivity } \\
\text { (All) } \\
(\mu \mathrm{S} / \mathrm{cm})\end{array}$ & $\begin{array}{c}\text { Conductivity } \\
\text { ( East) } \\
(\mu \mathrm{S} / \mathrm{cm})\end{array}$ & $\begin{array}{c}\text { Conductivity } \\
\text { (West) } \\
(\mu S / c m)\end{array}$ \\
\hline Mar-93 & 4808 & 242 & 8999 & 62 & 43 & 88 \\
\hline Jun-93 & 7617 & 389 & 14779 & 82 & 53 & 122 \\
\hline Sep-93 & 10924 & 445 & 22017 & 92 & 57 & 140 \\
\hline Dec-93 & 8182 & 435 & 15527 & 68 & 56 & 86 \\
\hline Jun-94 & 8557 & 324 & 14557 & 58 & 53 & 68 \\
\hline Sep-94 & 8065 & 303 & 15469 & 57 & 53 & 65 \\
\hline May-95 & 4323 & 270 & 6630 & 69 & 64 & 79 \\
\hline Mar-96 & 4069 & 143 & 7483 & 43 & 36 & 53 \\
\hline Sep-96 & 4260 & 183 & 7121 & 44 & 37 & 54 \\
\hline Mar-97 & 2730 & 136 & 3760 & 45 & 38 & 55 \\
\hline Seper6y & $7946^{*}$ & 981* & $8090^{\star}$ & 43 & 45 & 42 \\
\hline
\end{tabular}

Note: Due to many dry sites these averages are not representative of the areas and therefore not included in the statistical analysis and trending plots.

Table 8. Tritium concentrations for Fourmile Branch

\begin{tabular}{|c|c|c||c|c|c|}
\hline Sample date & Sample ID & Tritium (pCi/ml) & Sample date & Sample ID & Tritium (pCi/ml) \\
\hline Dec-92 & FMC001H & 55 & Dec-94 & FMC001F & 312 \\
\hline Dec-92 & FMC001F & 455 & Dec-94 & FMC001H & 59 \\
\hline Dec-92 & FMC002H & 2050 & Dec-94 & FMC002H & 113 \\
\hline Apr-93 & FMC001H & 47 & May-95 & FMC001F & 643 \\
\hline Apr-93 & FMC001F & 425 & May-95 & FMC001H & 63 \\
\hline Apr-93 & FMC002H & 104 & May-95 & FMC002H & 97 \\
\hline Sep-93 & FMC001H & 41 & Mar-96 & FMC001F & 138 \\
\hline Sep-93 & FMC002H & 105 & Mar-96 & FMC001H & 34 \\
\hline Sep-93 & FMC001F & 503 & Mar-96 & FMC002H & 65 \\
\hline Dec-93 & FMC001H & 37 & Sep-96 & FMC001F & 520 \\
\hline Dec-93 & FMC001F & 567 & Sep-96 & FMC001H & 35 \\
\hline Dec-93 & FMC002H & 145 & Sep-96 & FMC002H & 76 \\
\hline Mar-94 & FMC001H & 34 & Mar-97 & FMC001F & 329 \\
\hline Mar-94 & FMC001F & 375 & Mar-97 & FMC001H & 9 \\
\hline Mar-94 & FMC002H & 91 & Mar-97 & FMC002H & 78 \\
\hline Jun-94 & FMC001F & 331 & Sep-97 & FMC001F & 577 \\
\hline Jun-94 & FMC001H & 42 & Sep-97 & FMC001H & 16 \\
\hline Jun-94 & FMC002H & 82 & Sep-97 & FMC002H & 61 \\
\hline Sep-94 & FMC001F & 567 & & & \\
\hline Sep-94 & FMC001H & 52 & & & \\
\hline Sep-94 & FMC002H & 93 & & & \\
\hline
\end{tabular}




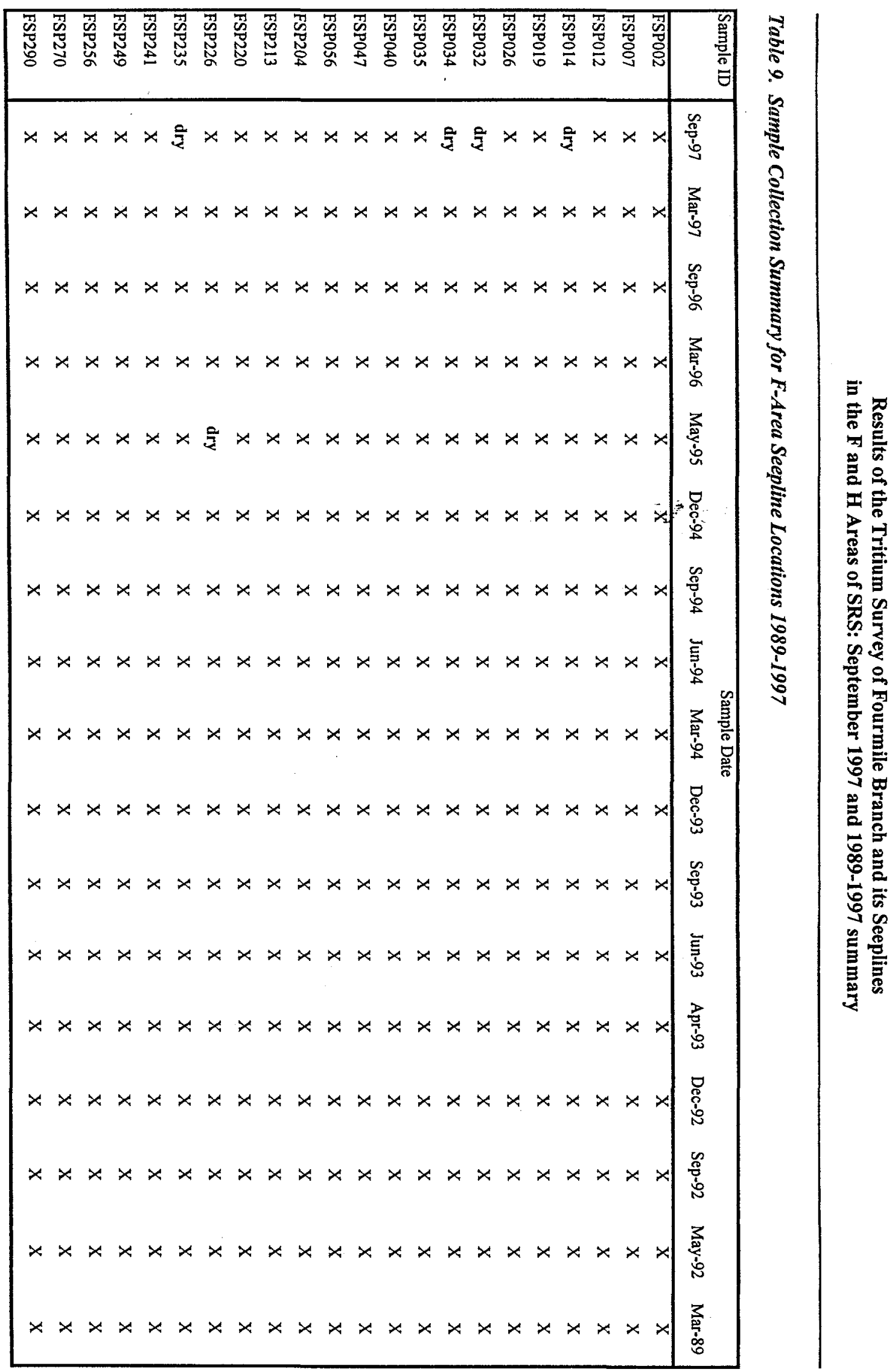




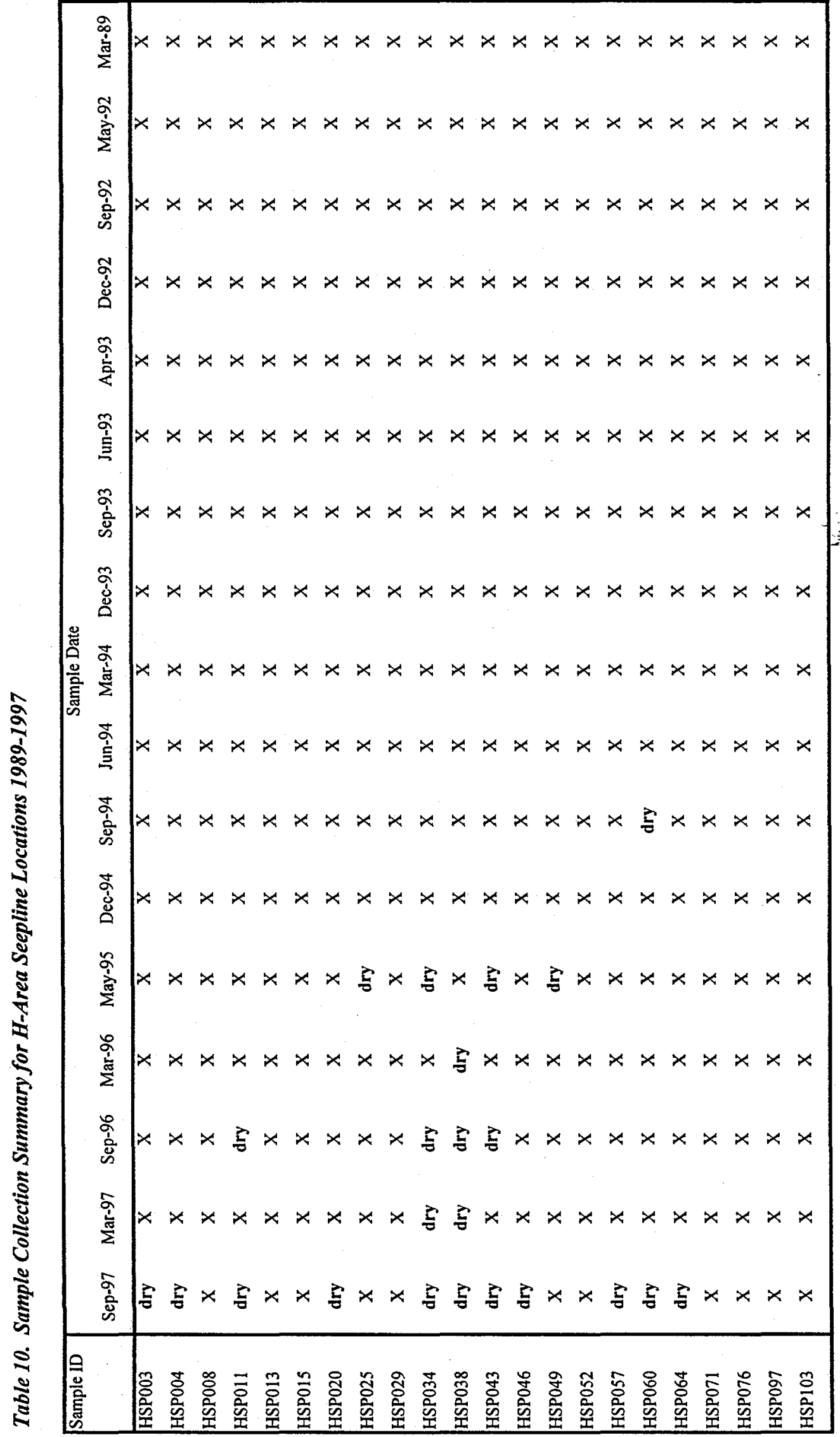


Results of the Tritium Survey of Fourmile Branch and its Seeplines

in the $F$ and $H$ Areas of SRS: September 1997 and 1989-1997 summary

Table 11. Sample Collection Summary for 643-E Seepline Locations 1992-1997

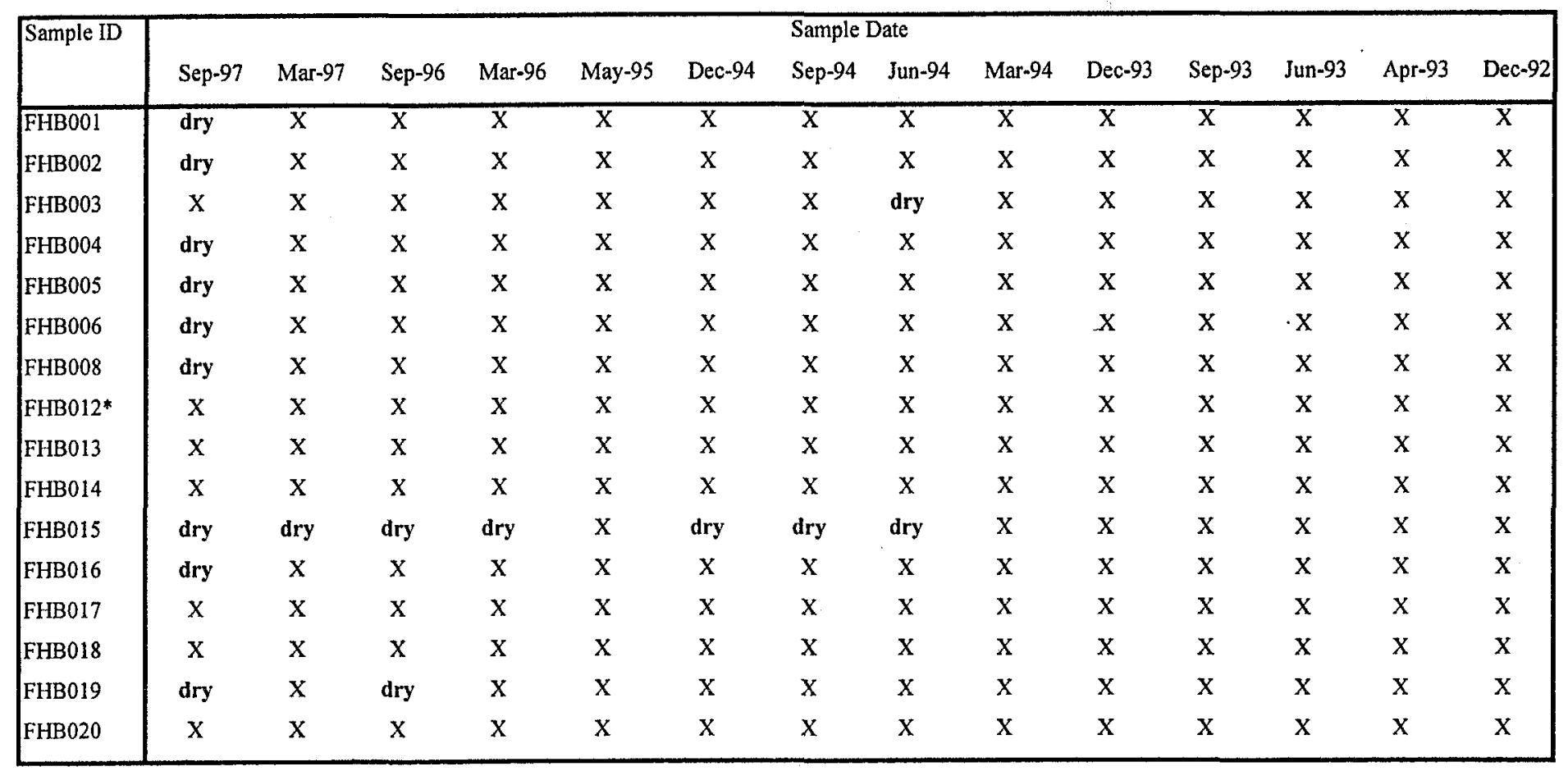

1 


\section{Appendix A}

F-Area Seepline

Tritium Concentrations and Conductivity Plotted by Sampling Location, 1989-1997 


\section{Sample Location FSP002}

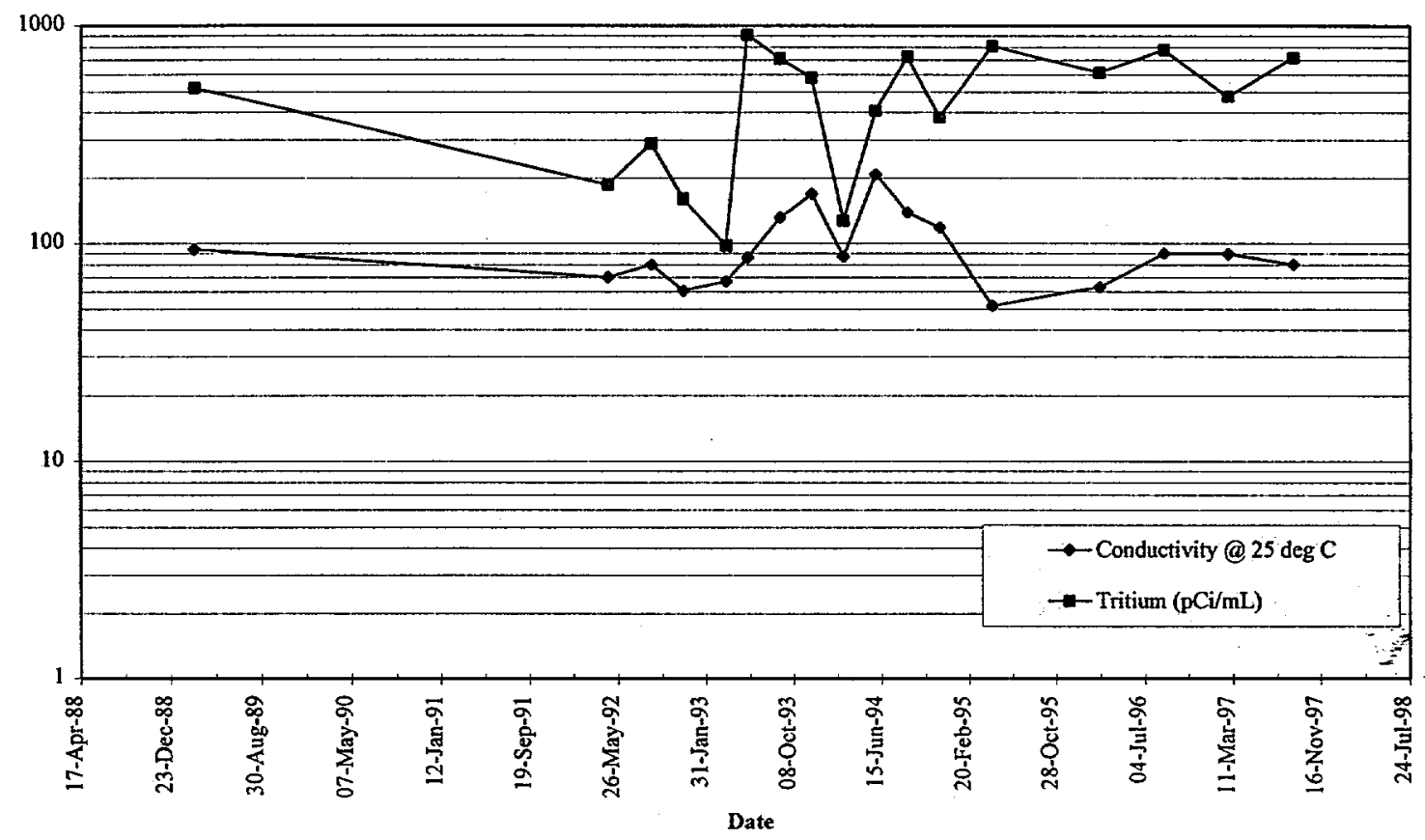

Sample Location FSP007

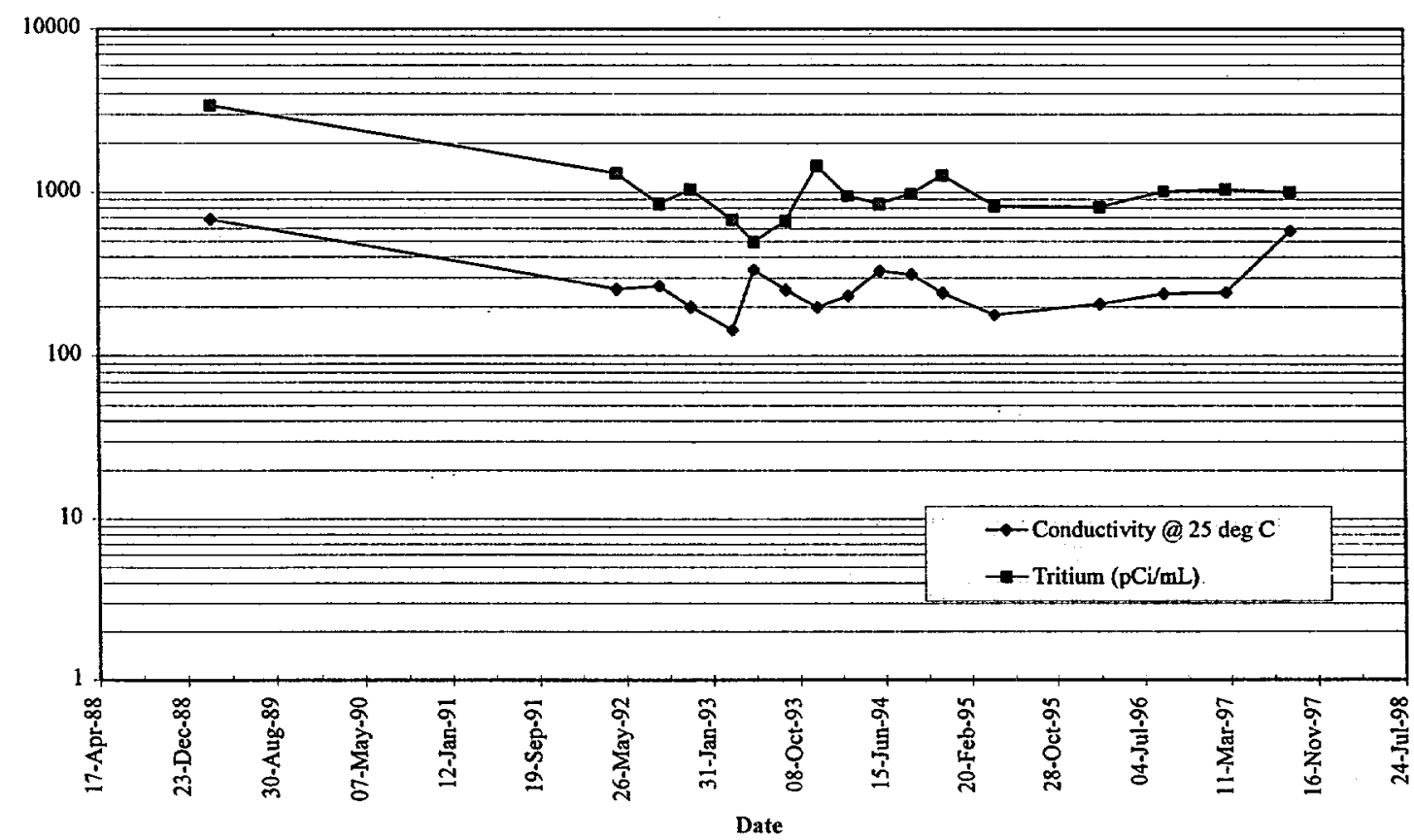




\section{Sample Location FSP012}

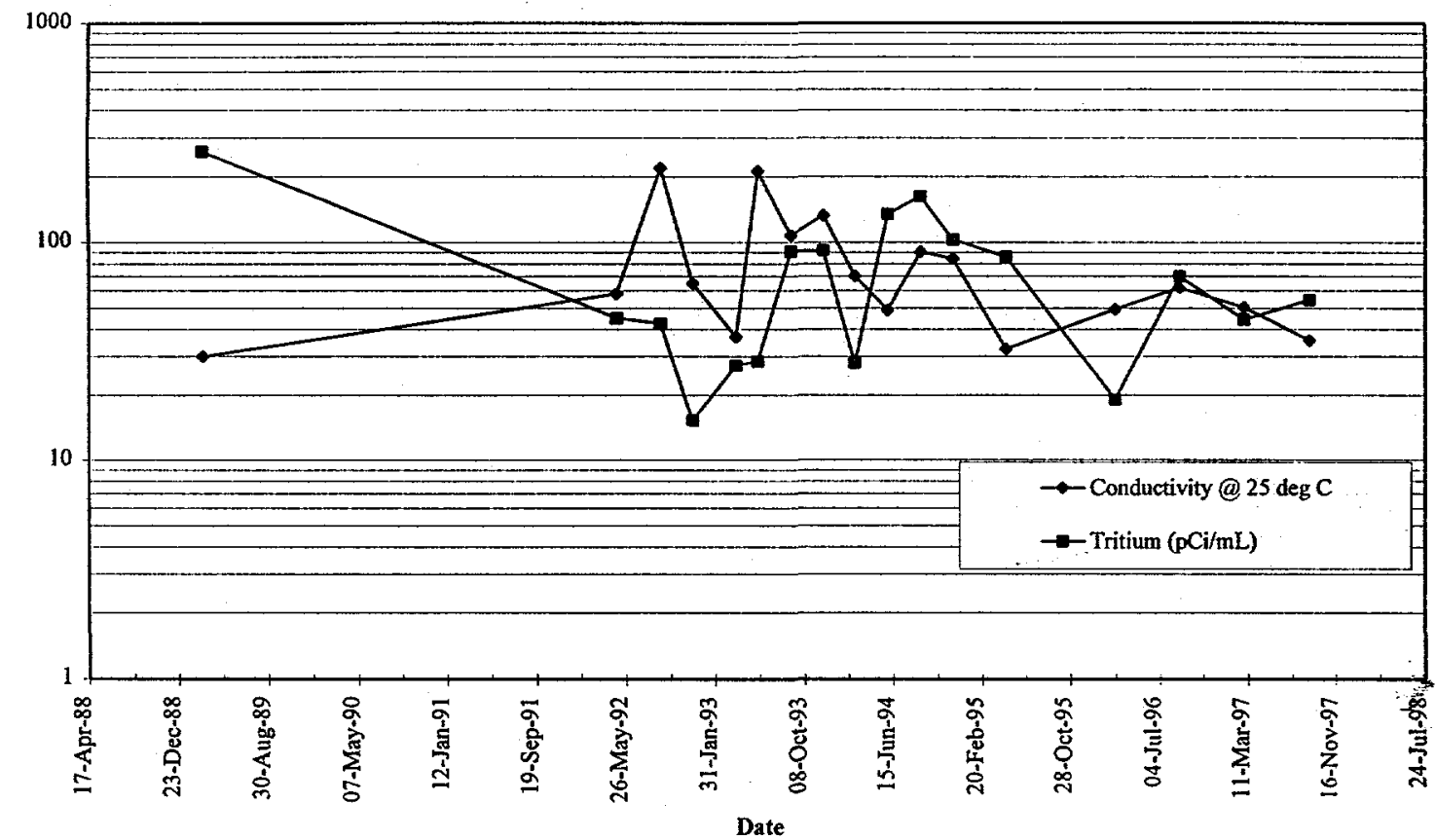

\section{Sample Location FSP014}

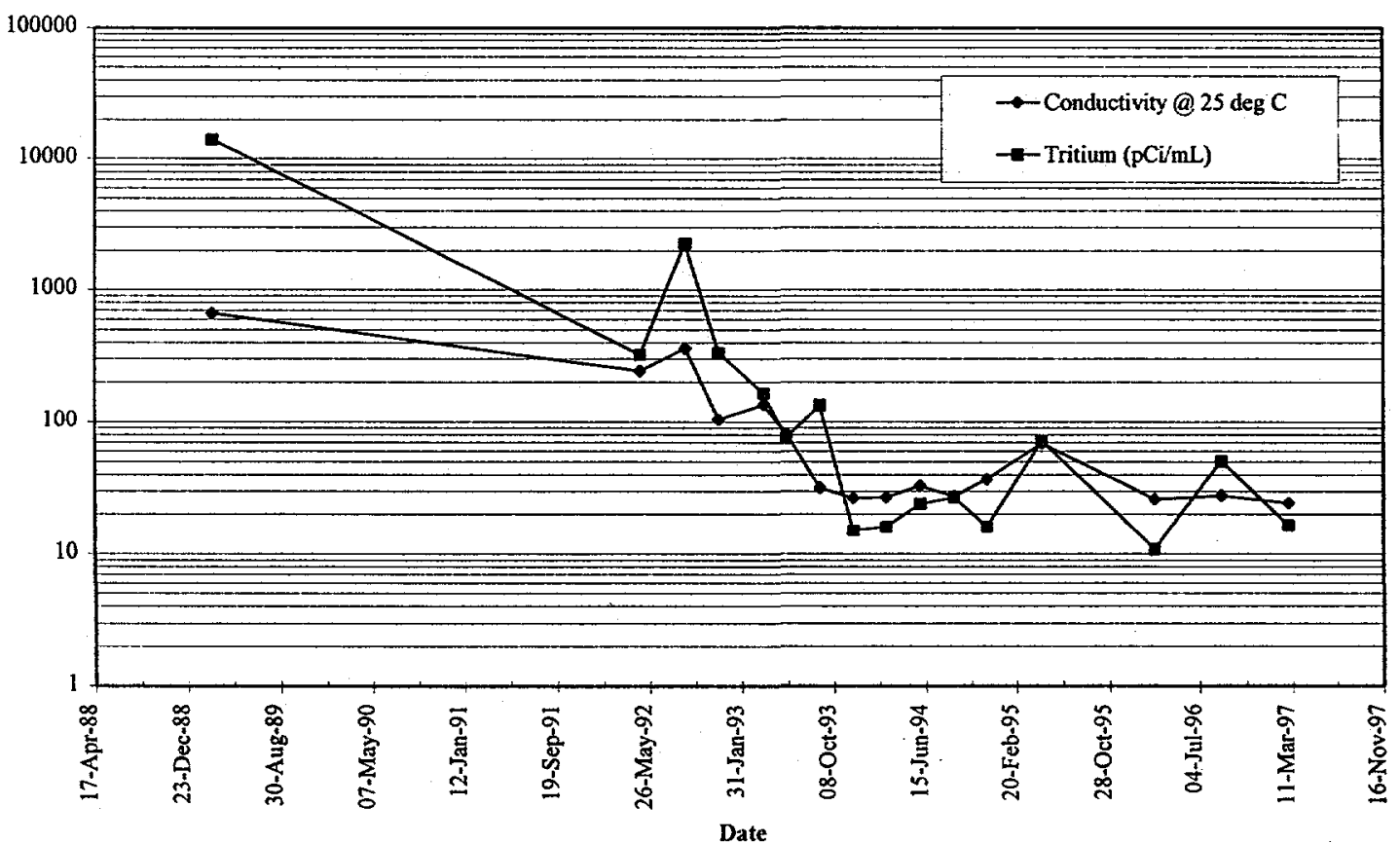


Results of the Tritium Survey of Fourmile Branch and its Seeplines in the F and $H$ Areas of SRS: September 1997 and 1989-1997 Summary

Sample Location FSP019

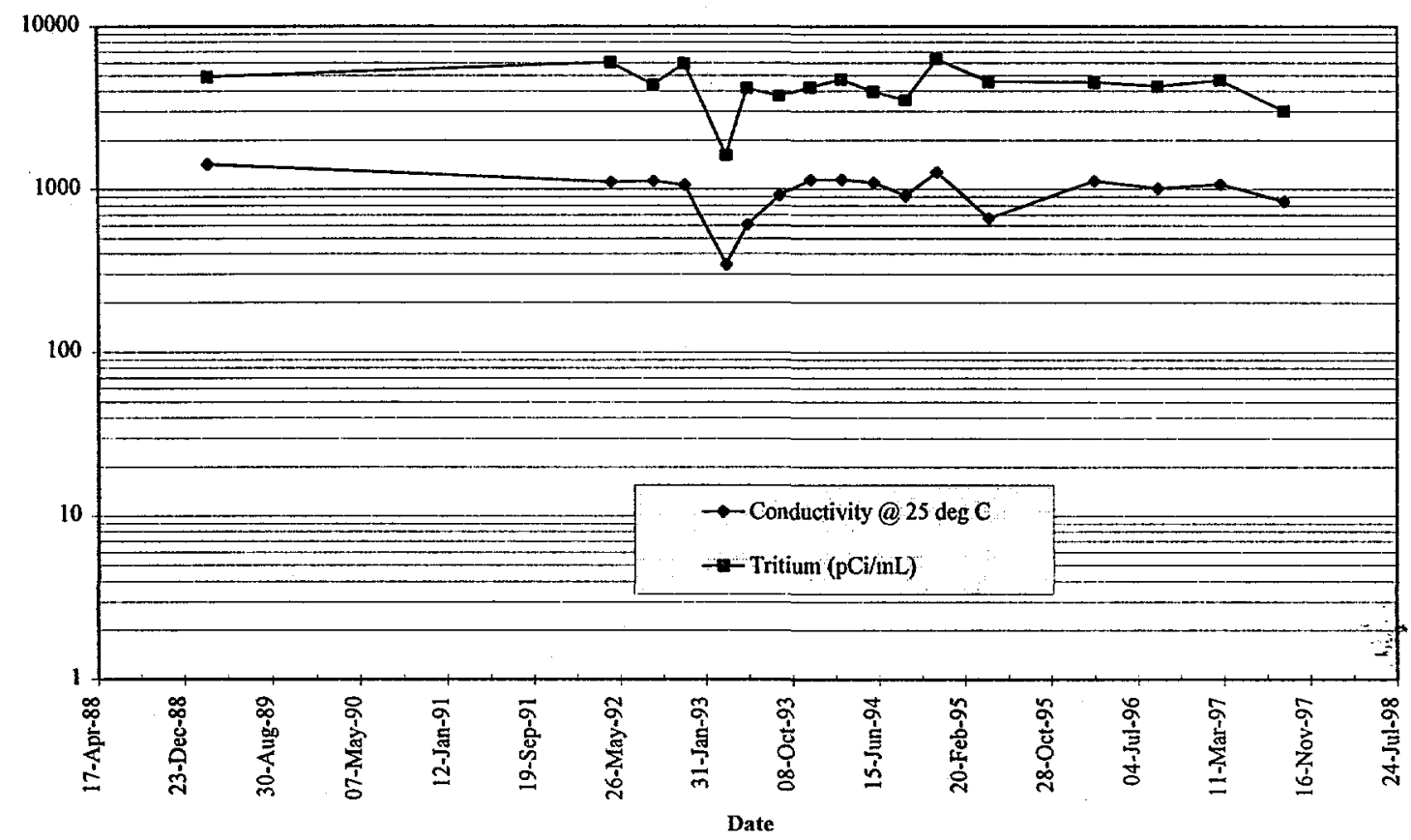

Sample Location FSP026

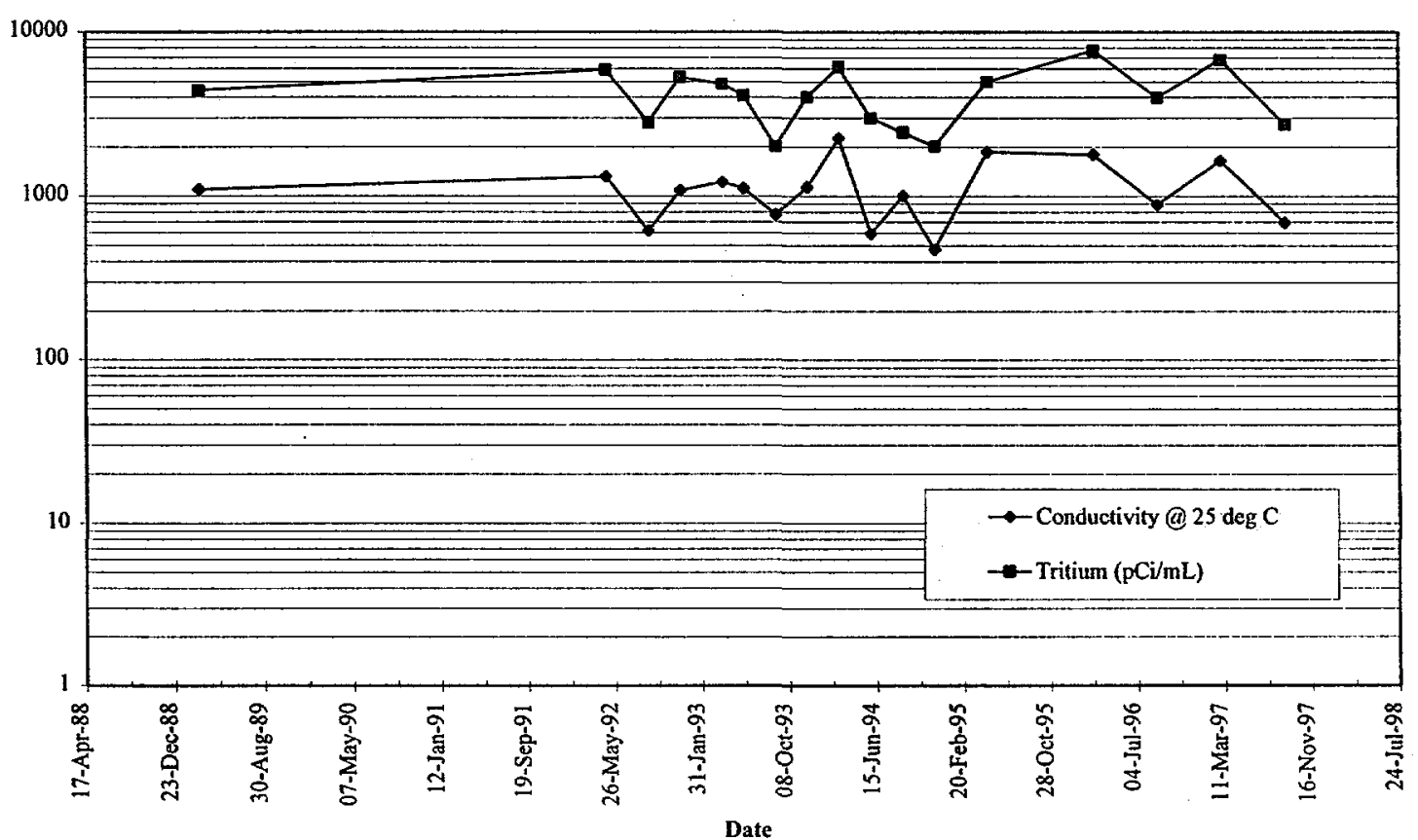




\section{Sample Location FSP032}

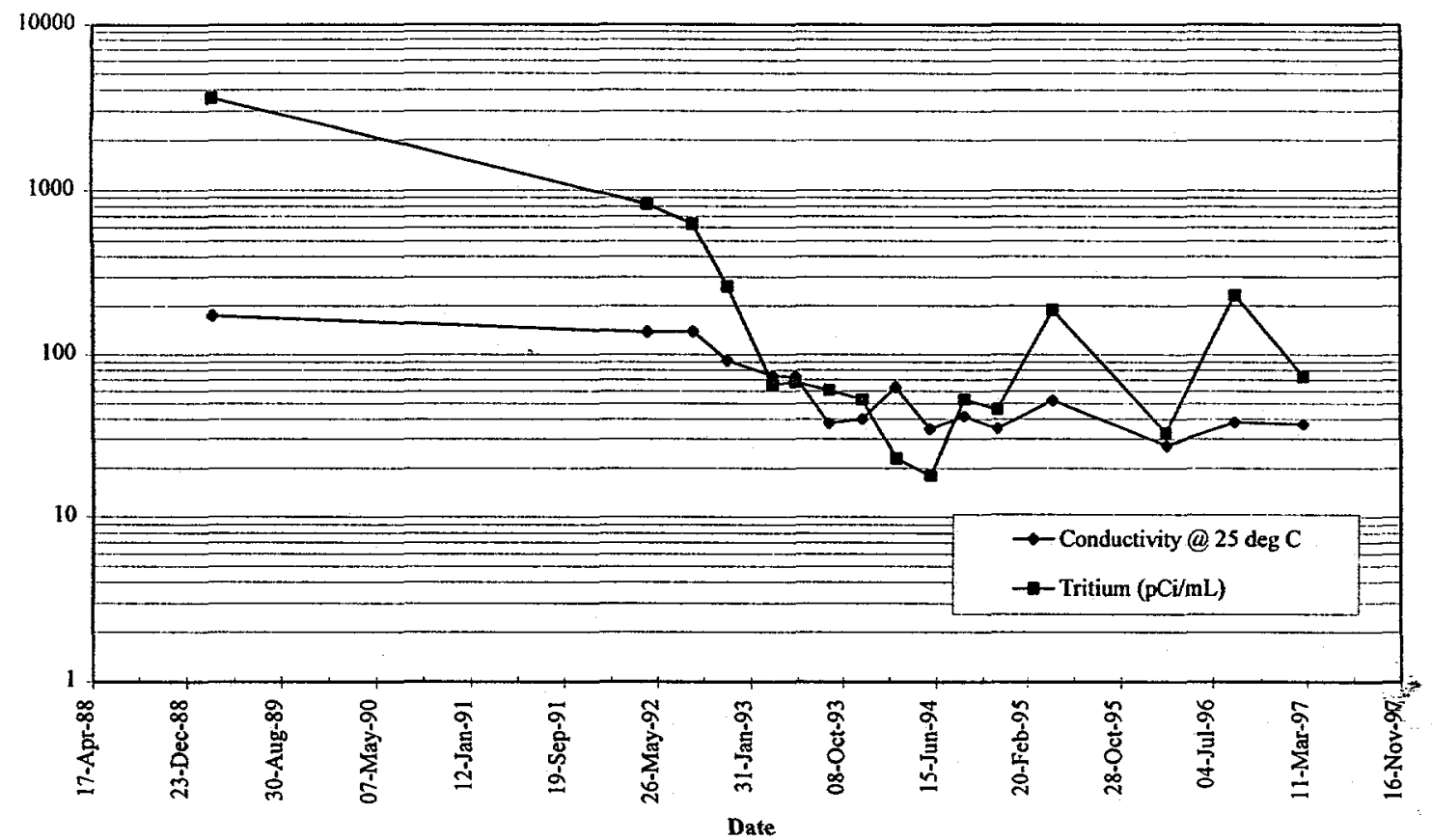

Sample Location FSP034

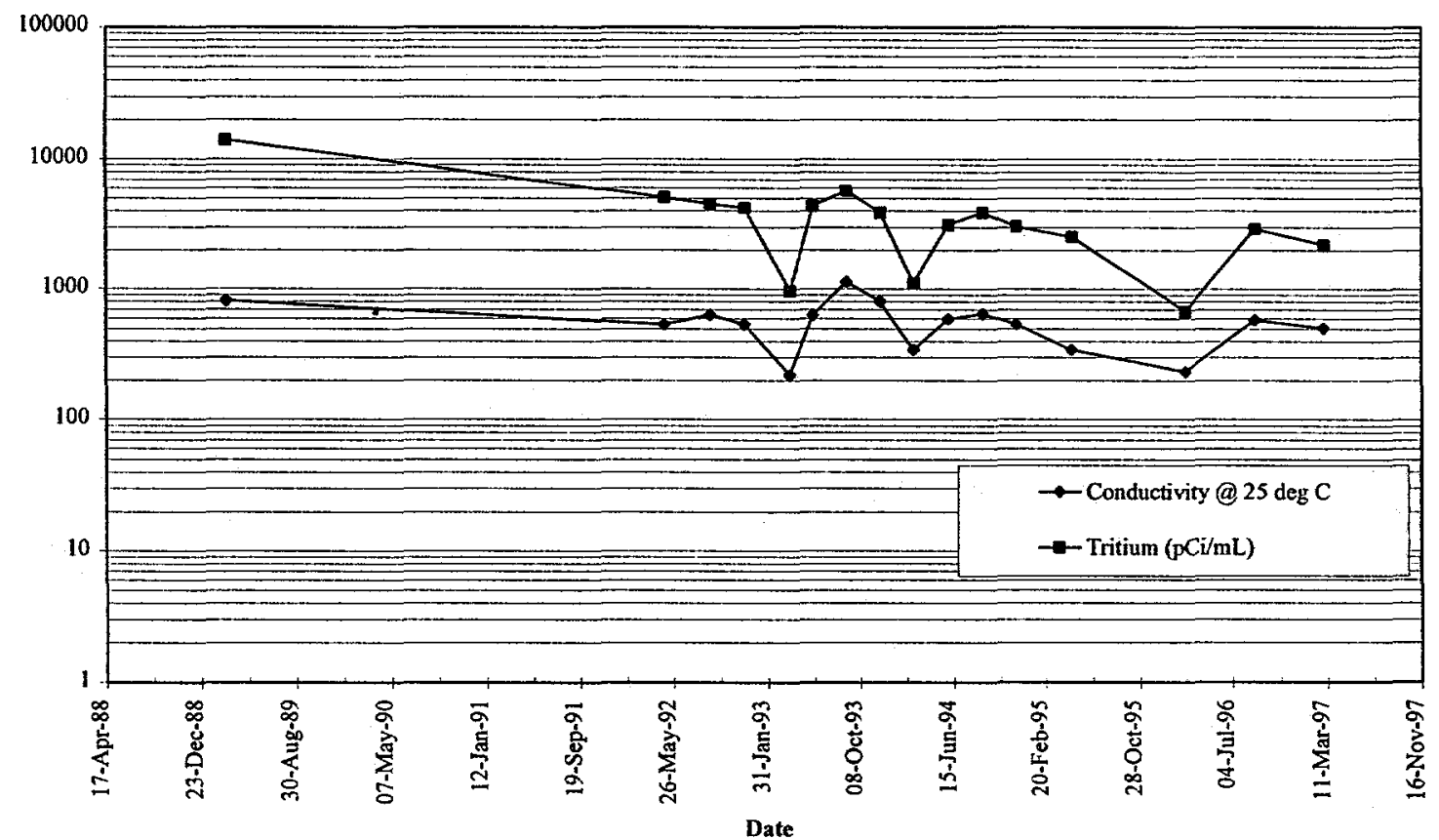


Results of the Tritium Survey of Fourmile Branch and its Seeplines in the F and $H$ Areas of SRS: September 1997 and 1989-1997 Summary

Sample Location FSP035

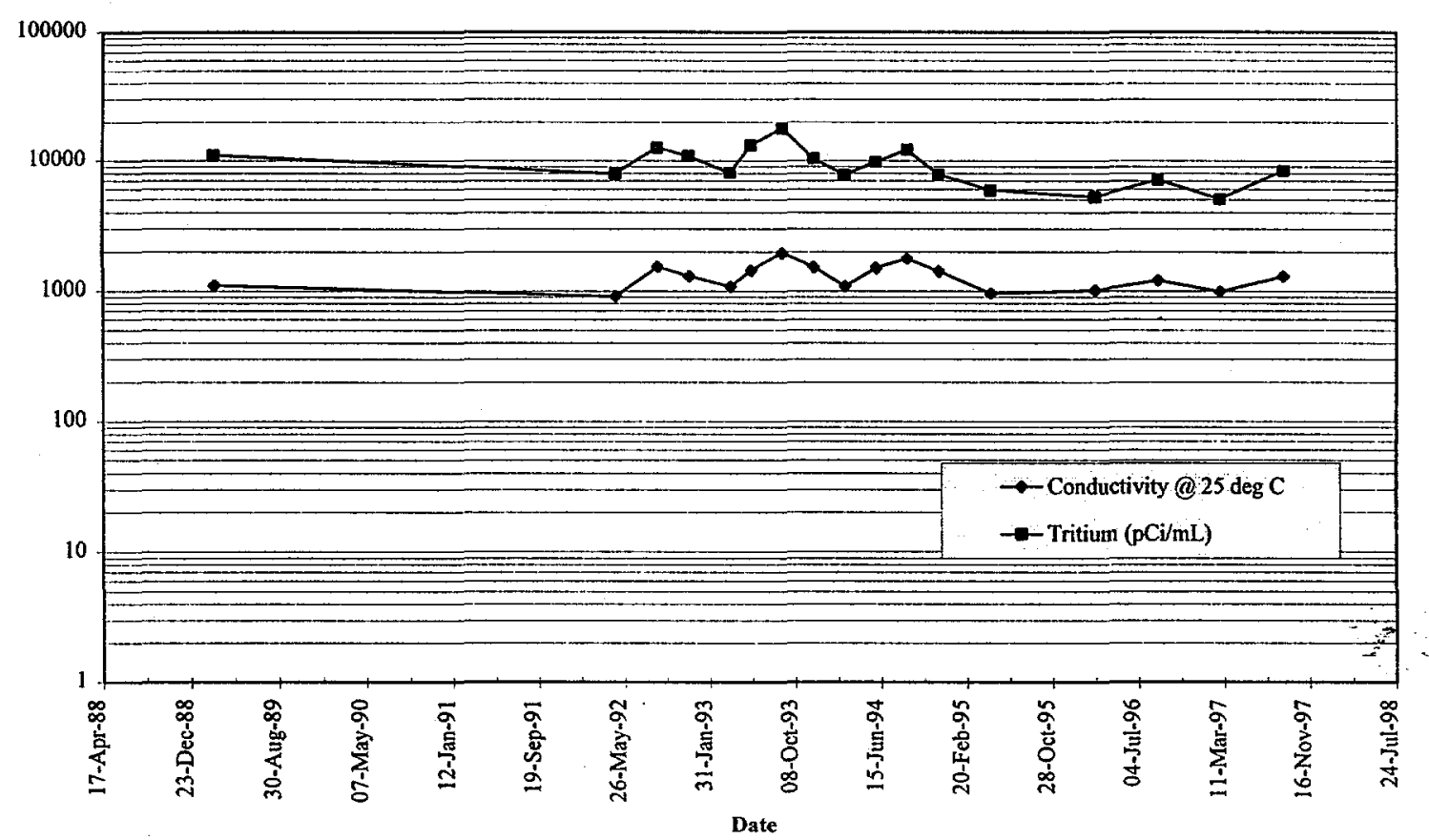

\section{Sample Location FSP040}

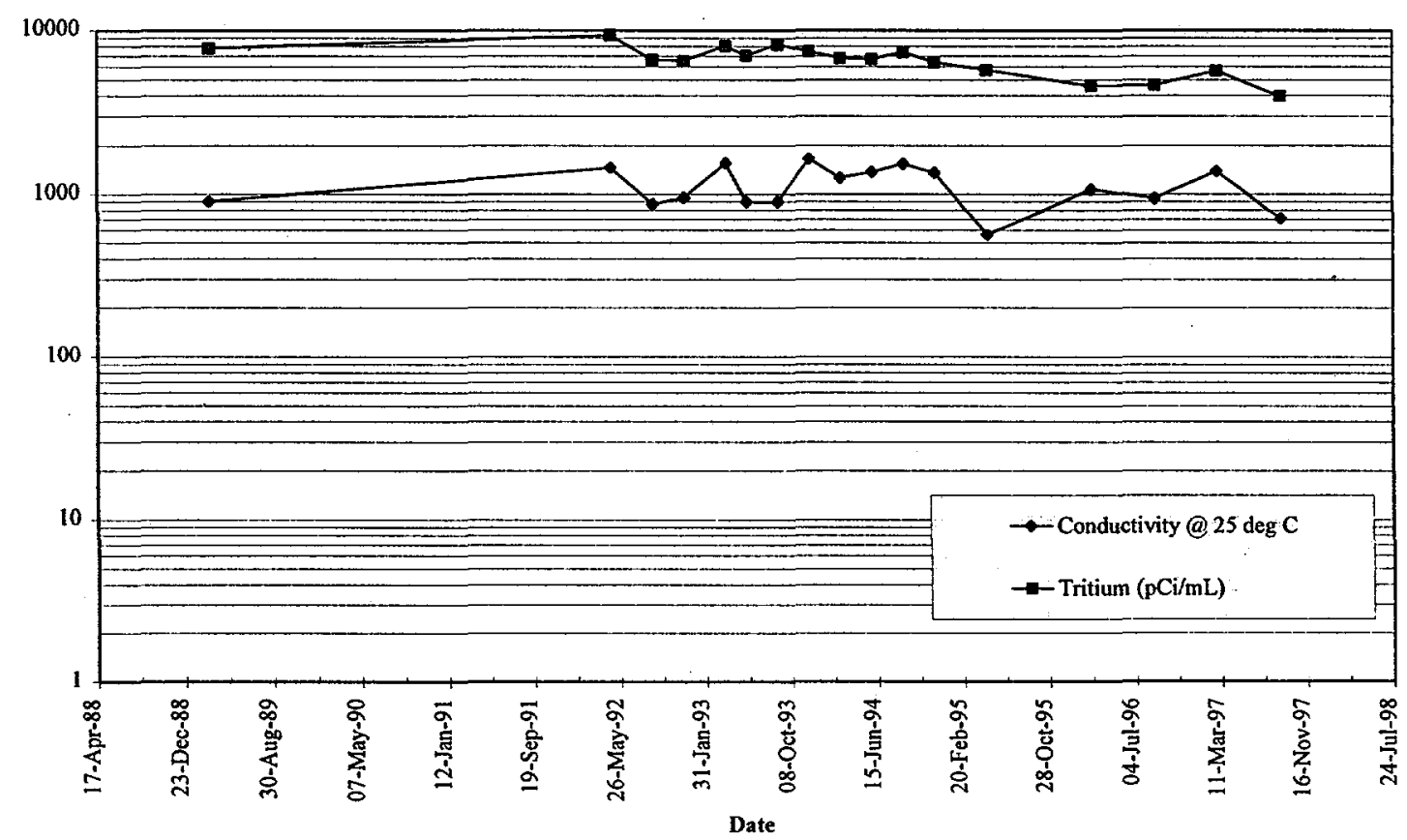




\section{Sample Location FSP047}

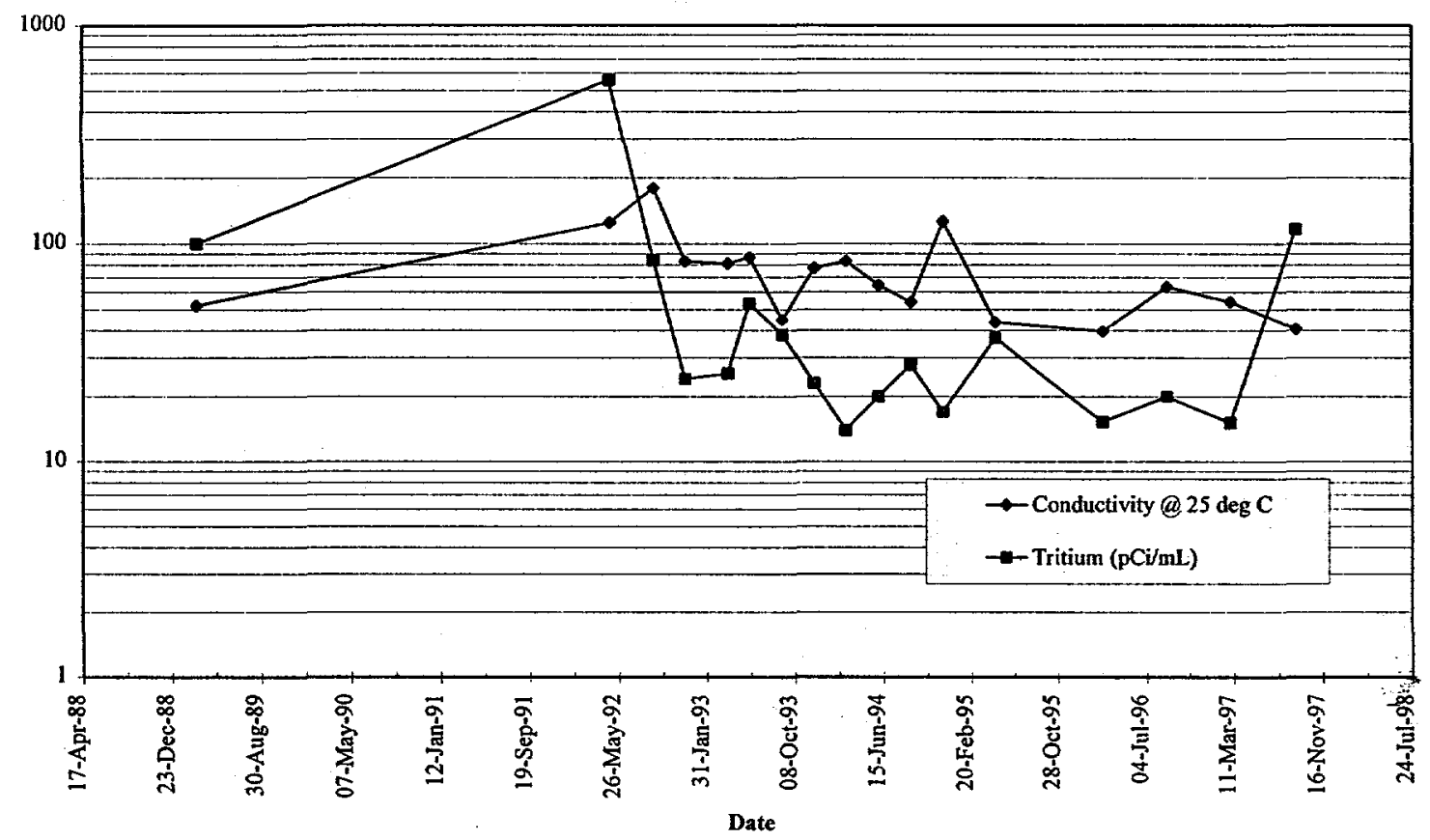

Sample Location FSP056

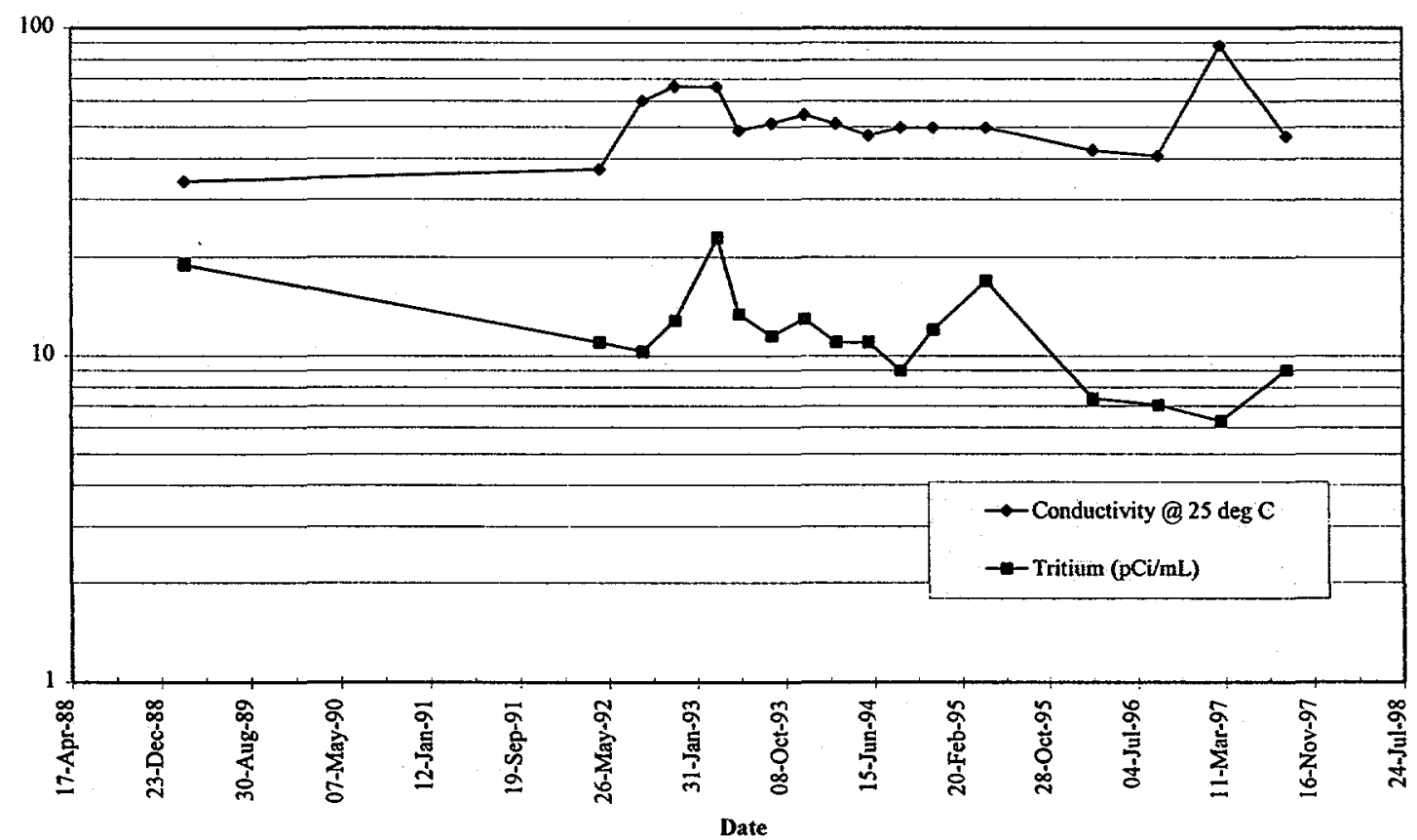


Results of the Tritium Survey of Fourmile Branch and its Seeplines in the F and $H$ Areas of SRS: September 1997 and 1989-1997 Summary

Sample Location FSP204

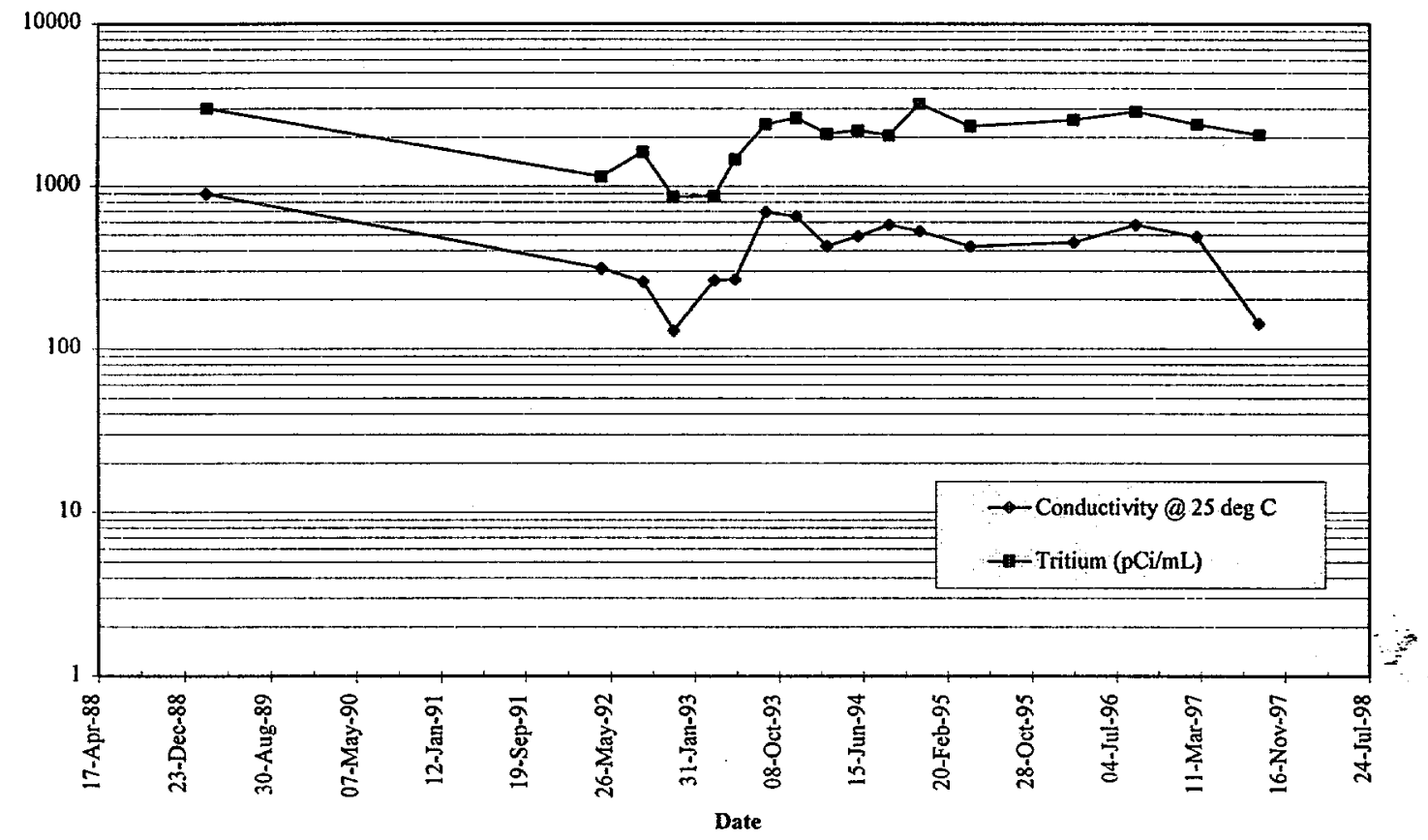

Sample Locaiton FSP213

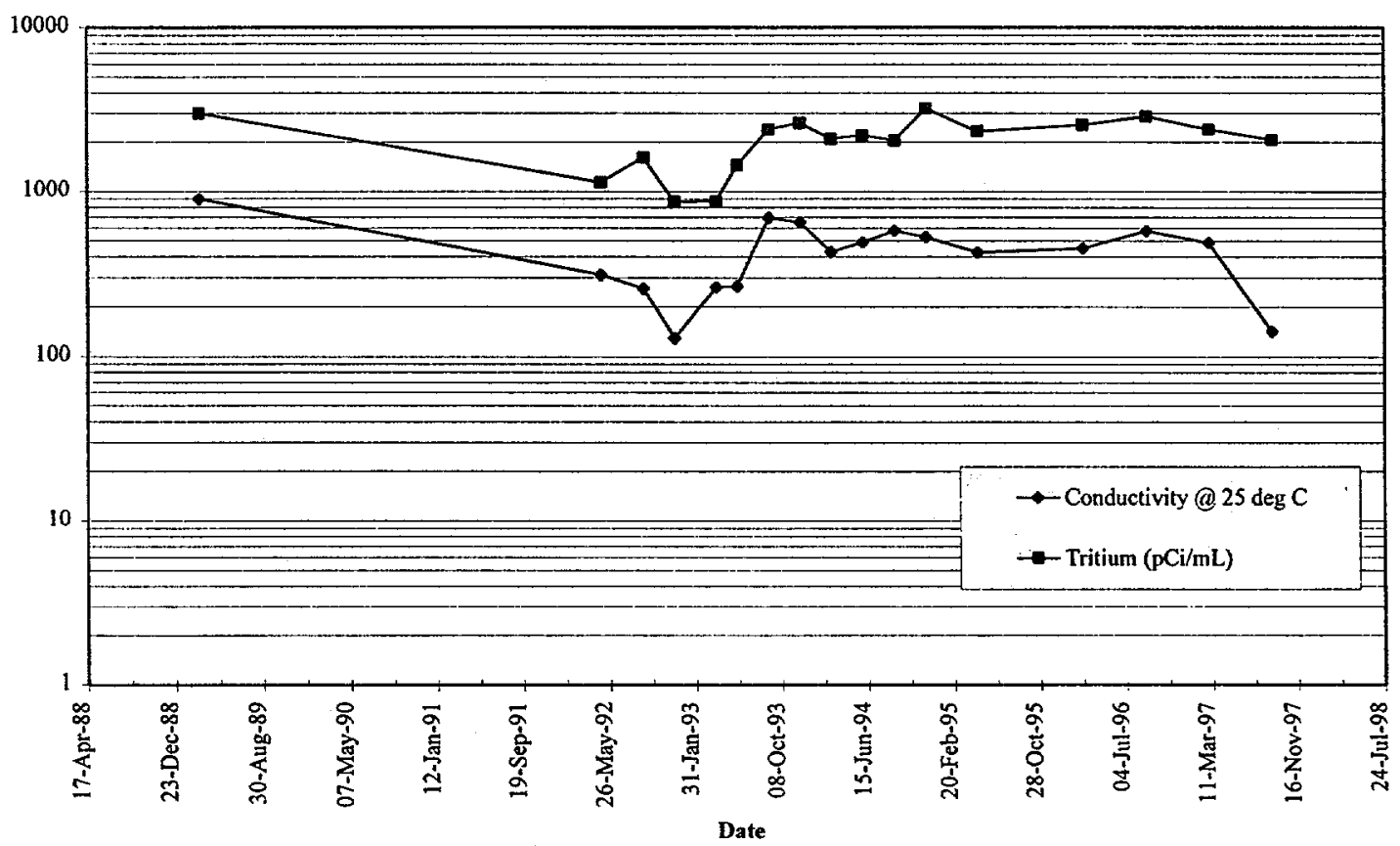


Sample Locaiton FSP220

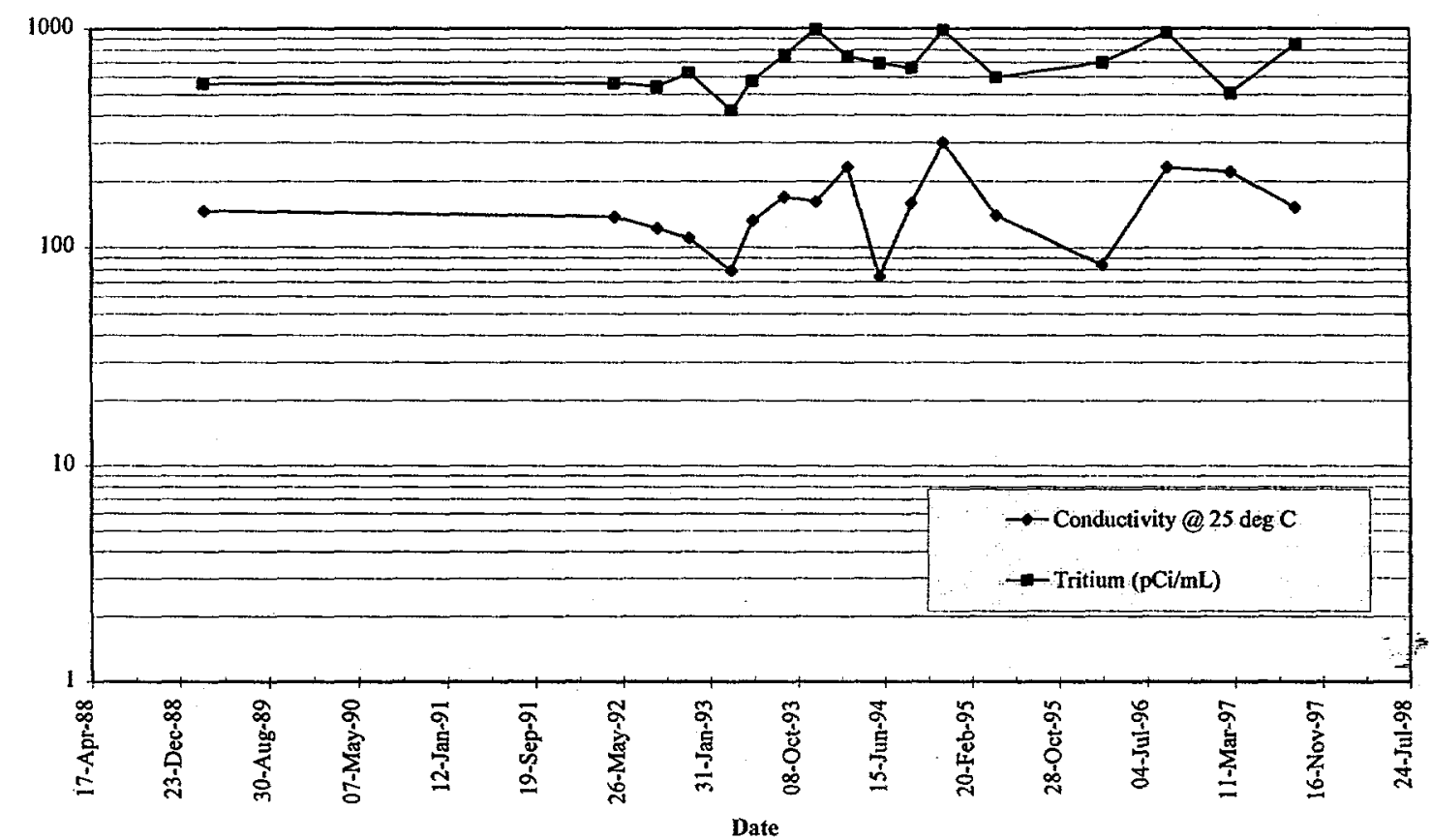

Sample Location FSP226

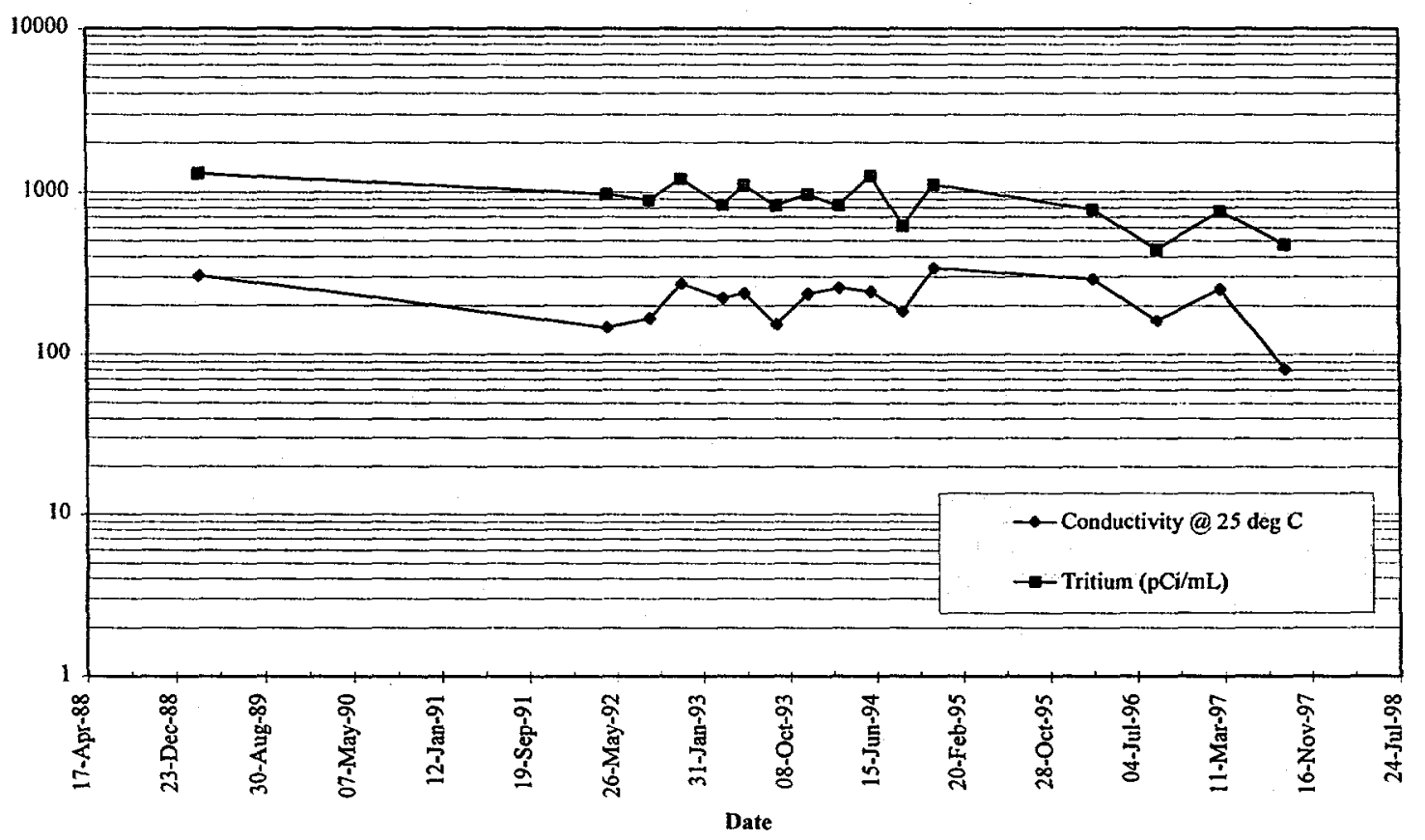


Results of the Tritium Survey of Fourmile Branch and its Seeplines in the F and H Areas of SRS: September 1997 and 1989-1997 Summary

Sample Location FSP235

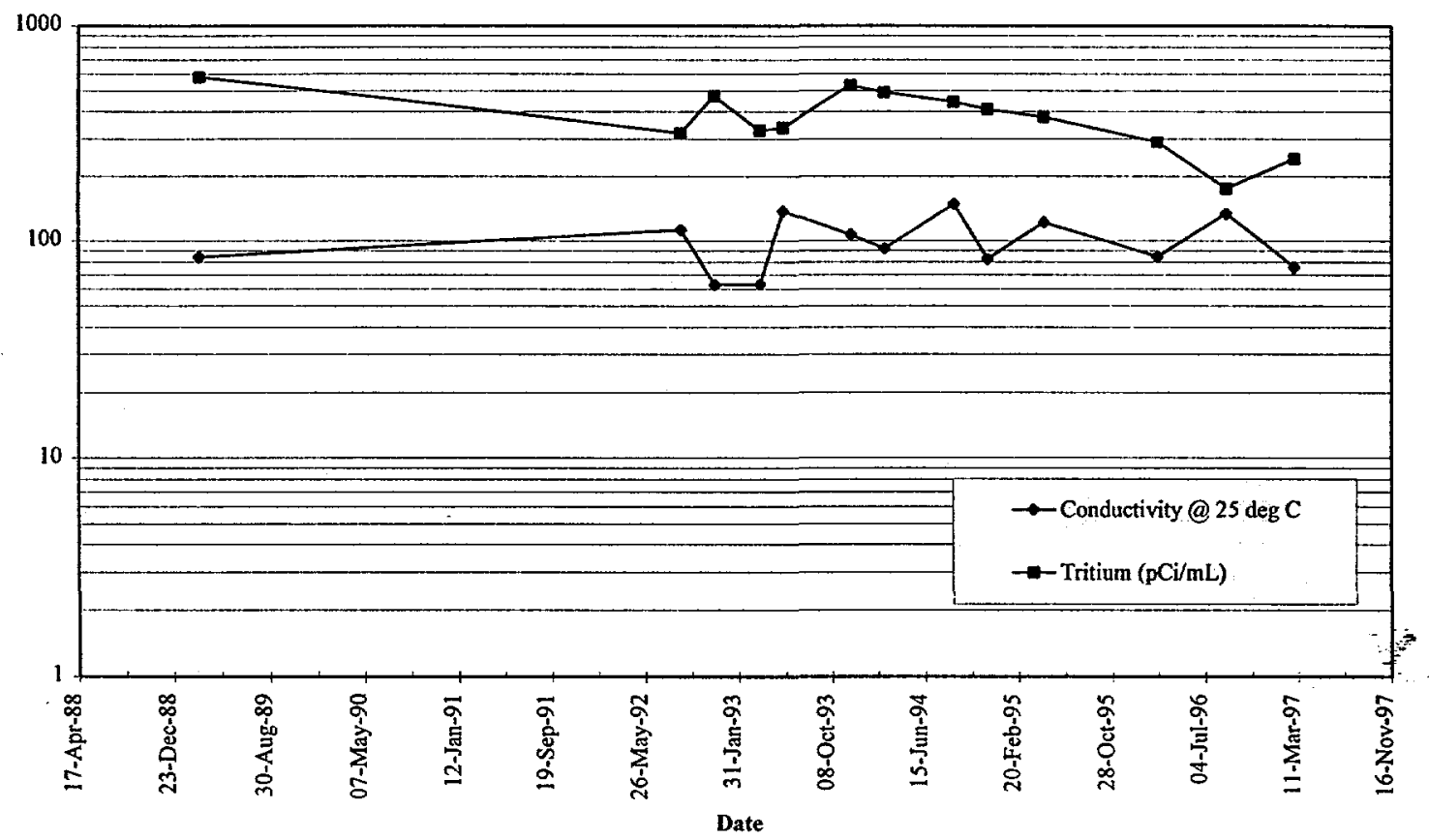

Sample Location FSP241

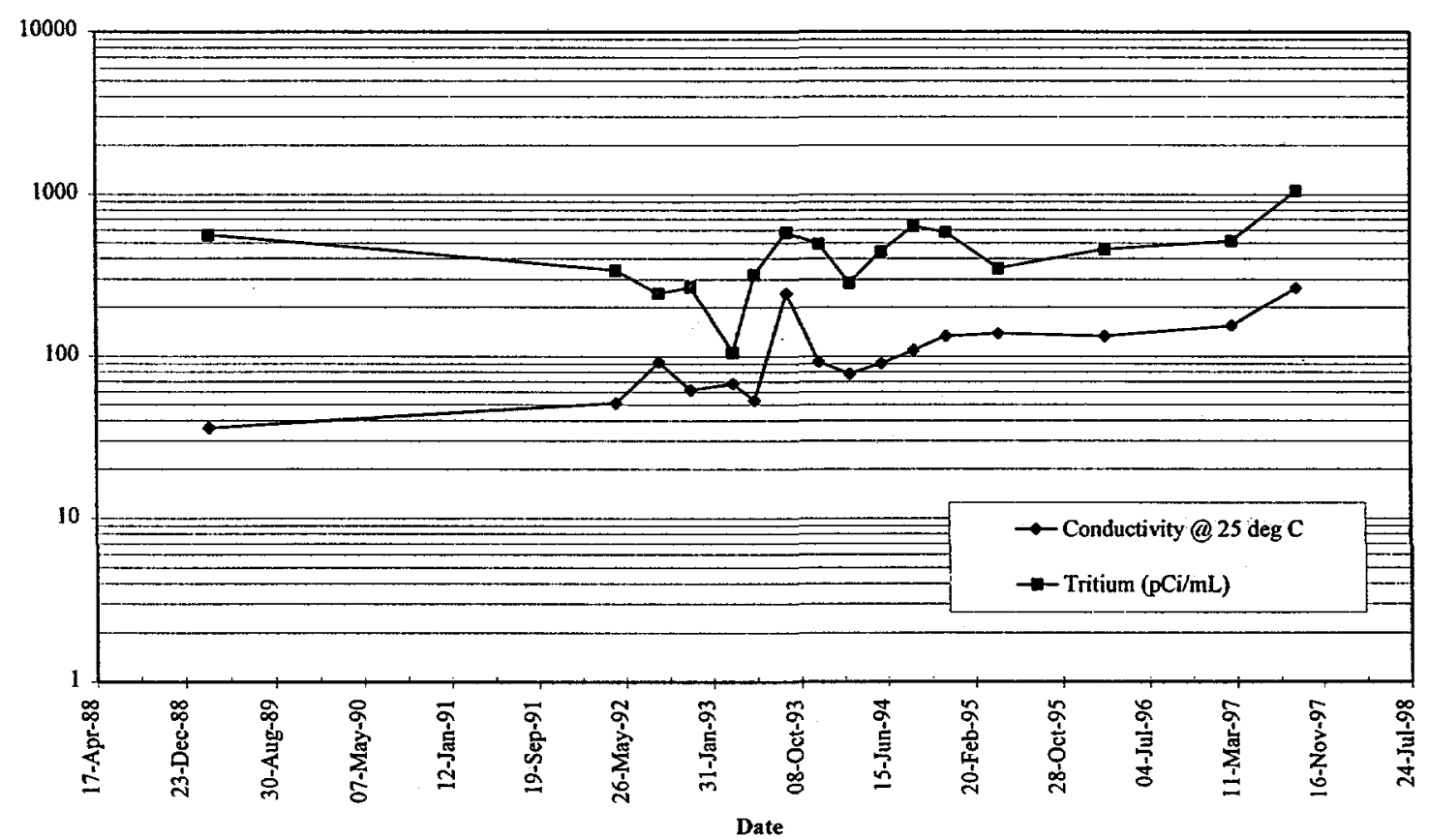


Sample Locaiton FSP249

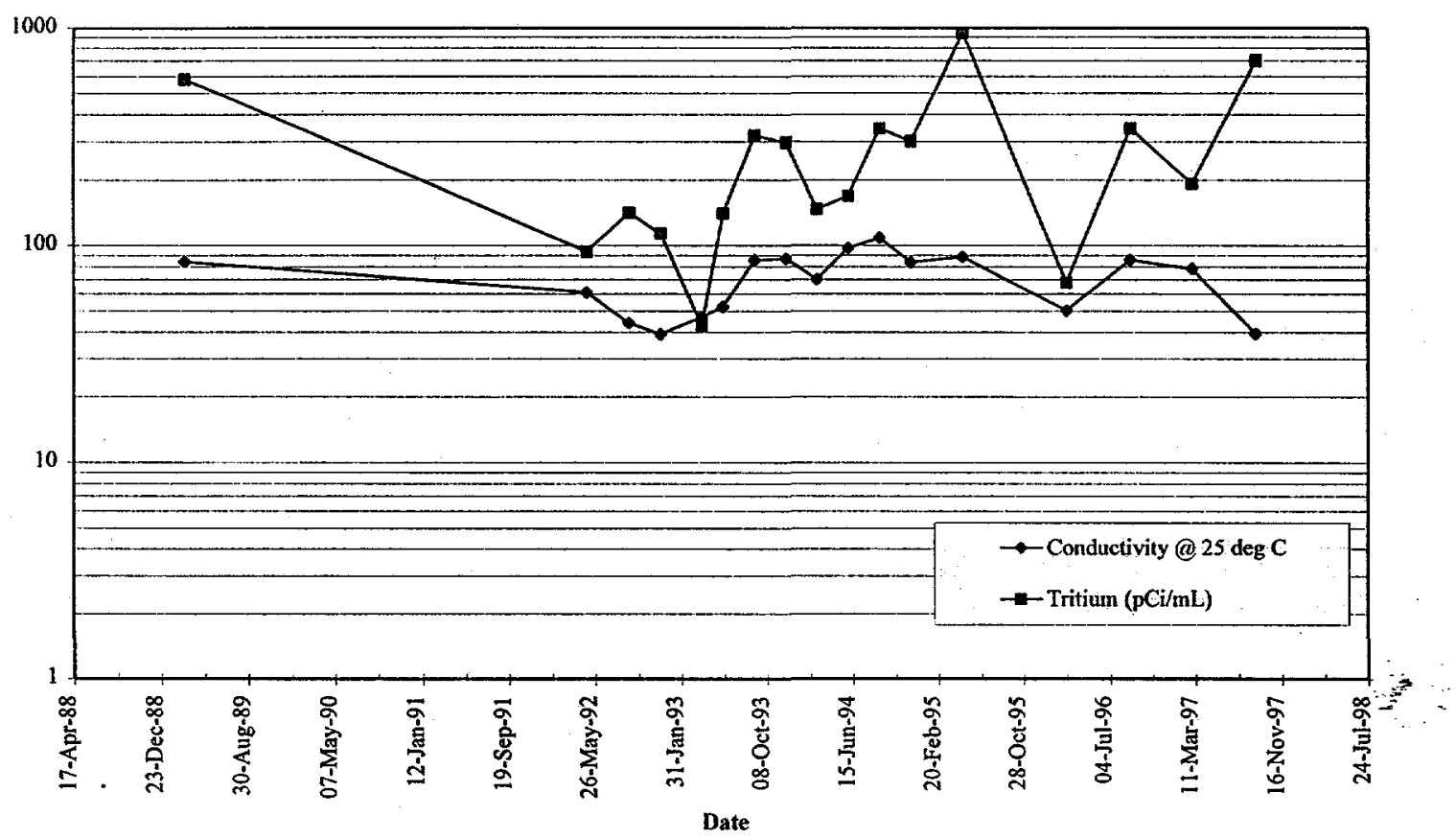

Sample Location FSP256

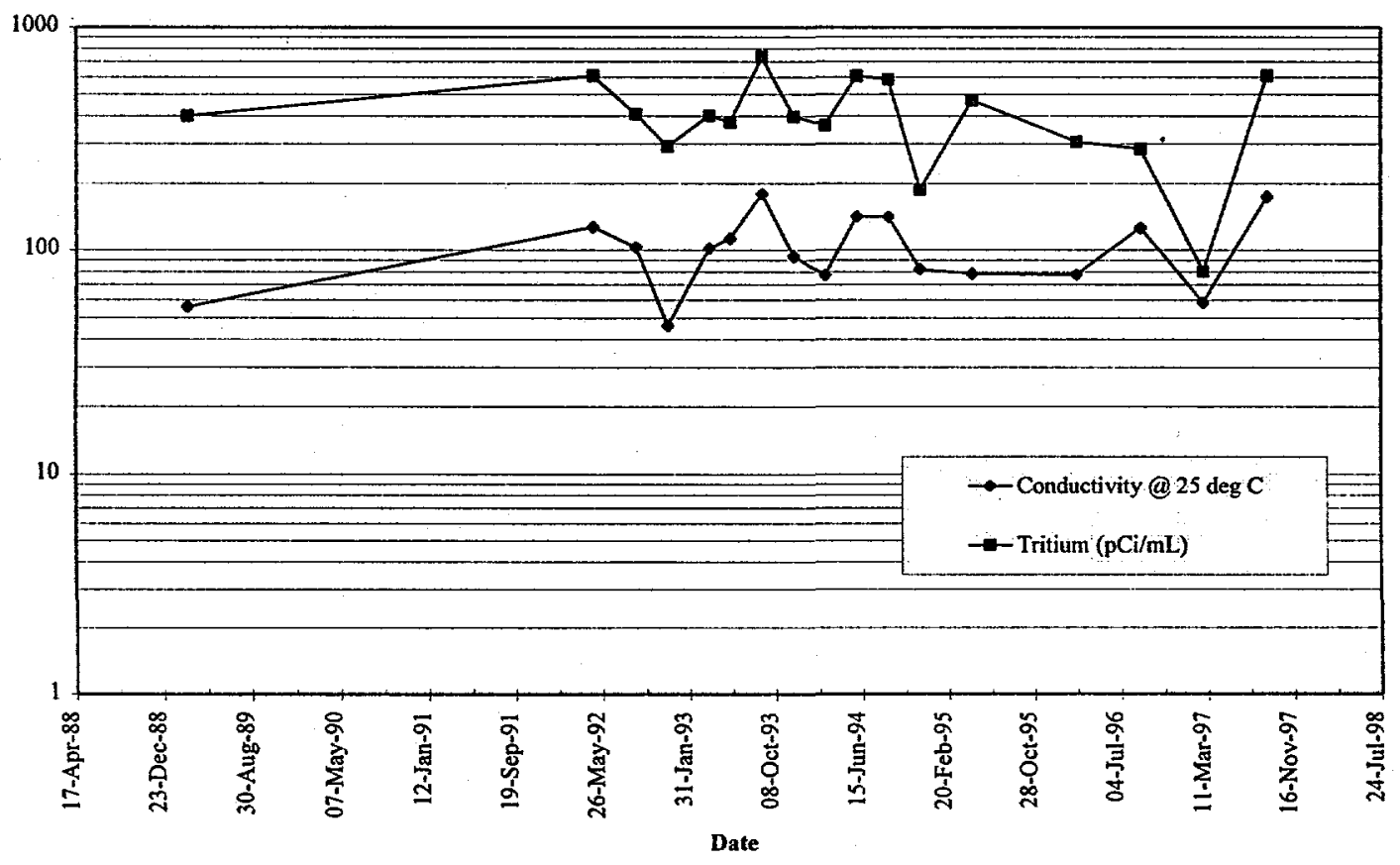


Results of the Tritium Survey of Fourmile Branch and its Seeplines

in the $F$ and $H$ Areas of SRS: September 1997 and 1989-1997 Summary

Sample Locaiton FSP270

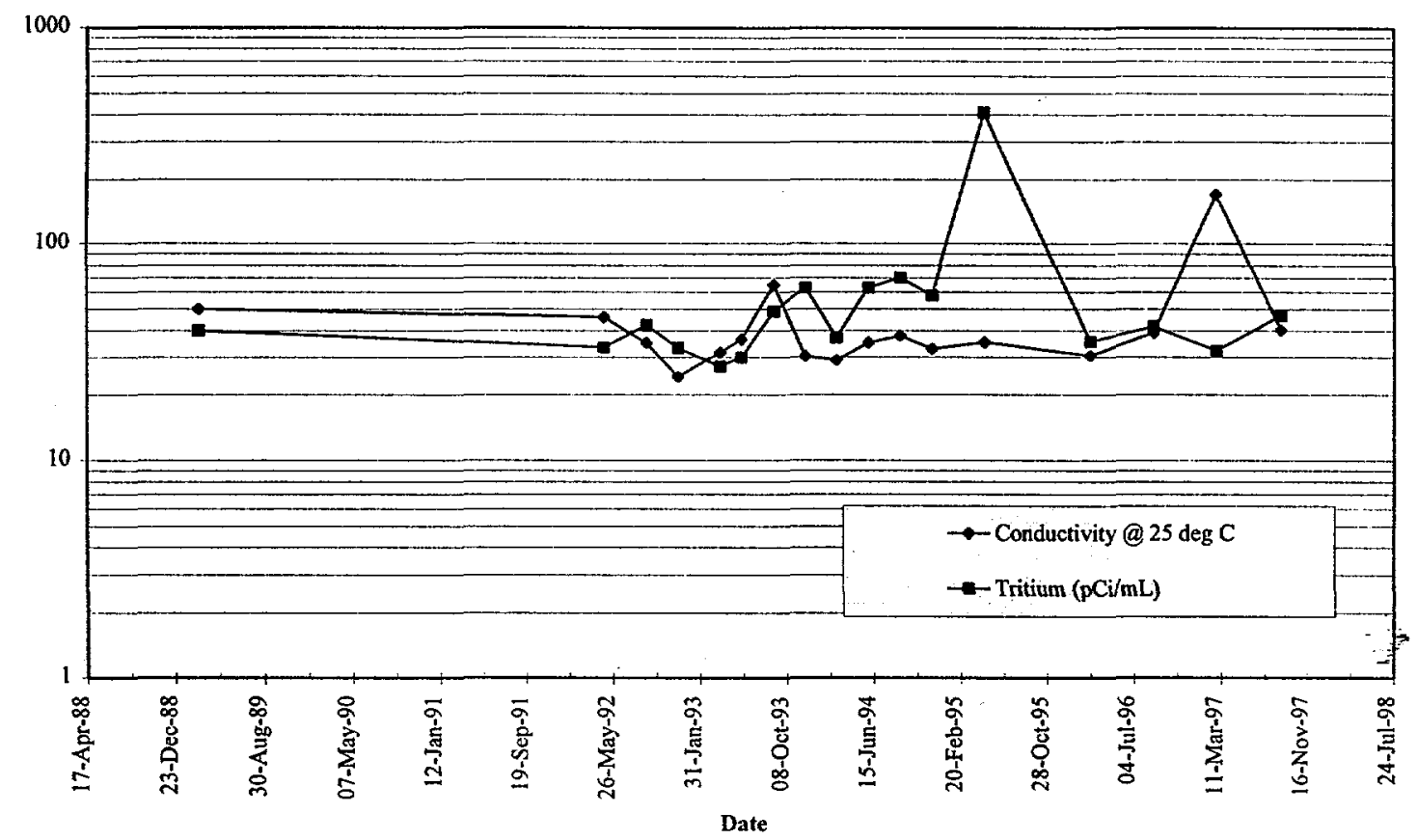

Sample Location FSP290

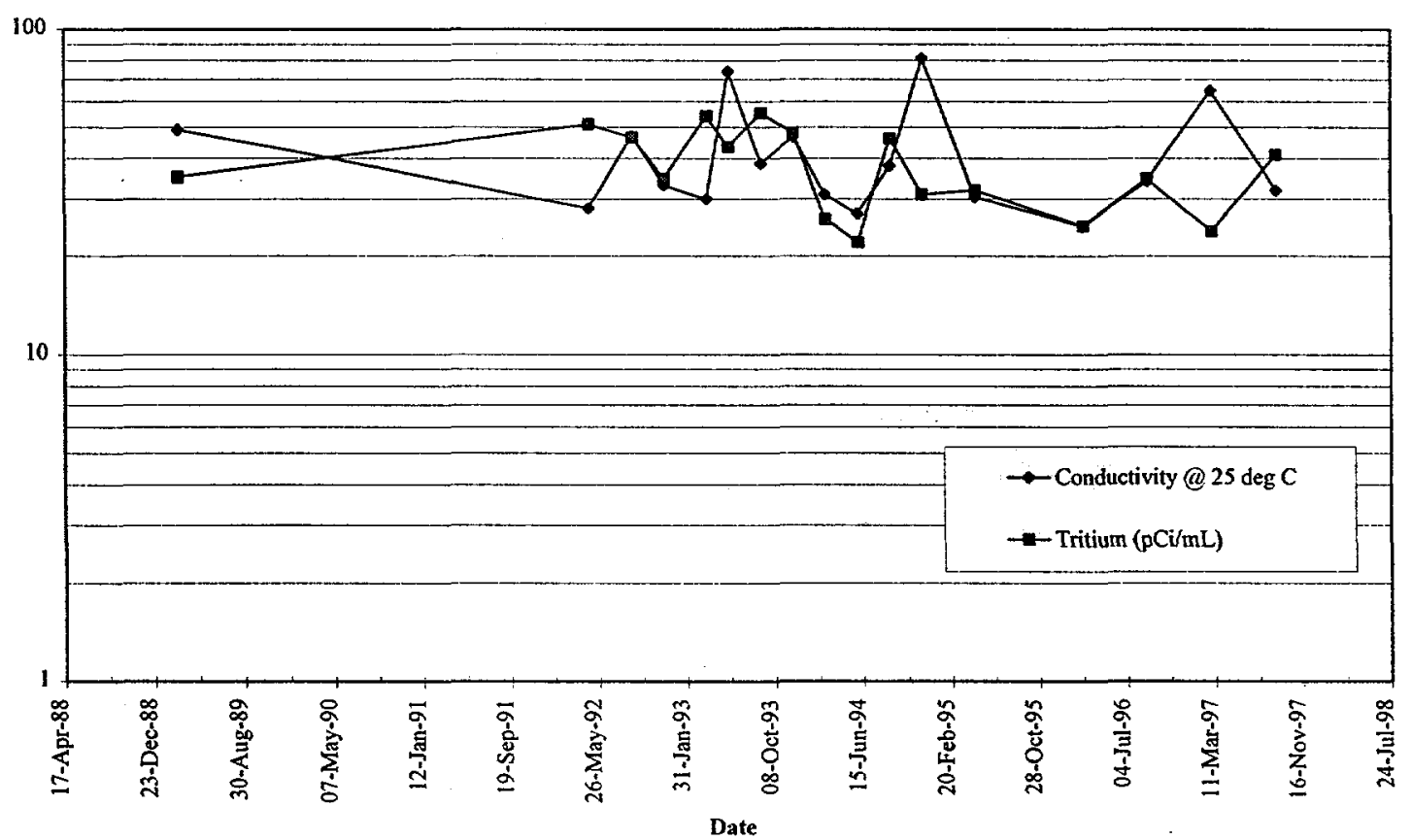




\title{
Appendix B
}

\author{
H-Area Seepline
}

Tritium Concentrations and Conductivity Plotted by Sampling Location, 1989-1997 
Results of the Tritium Survey of Fourmile Branch and its Seeplines in the F and H Areas of SRS: September 1997 and 1989-1997 Summary

\section{Sample Location HSP003}

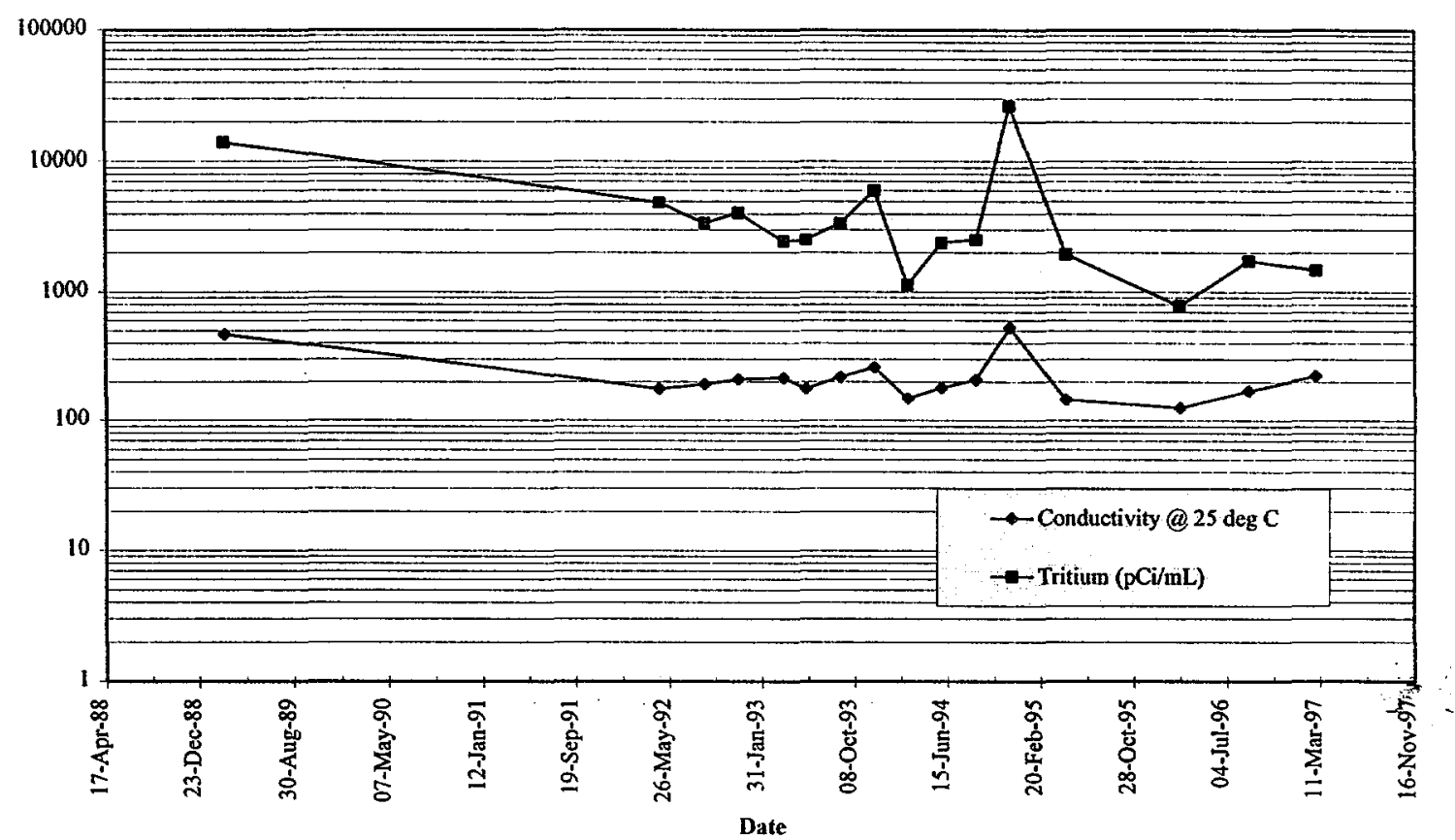

Sample Location HSP004

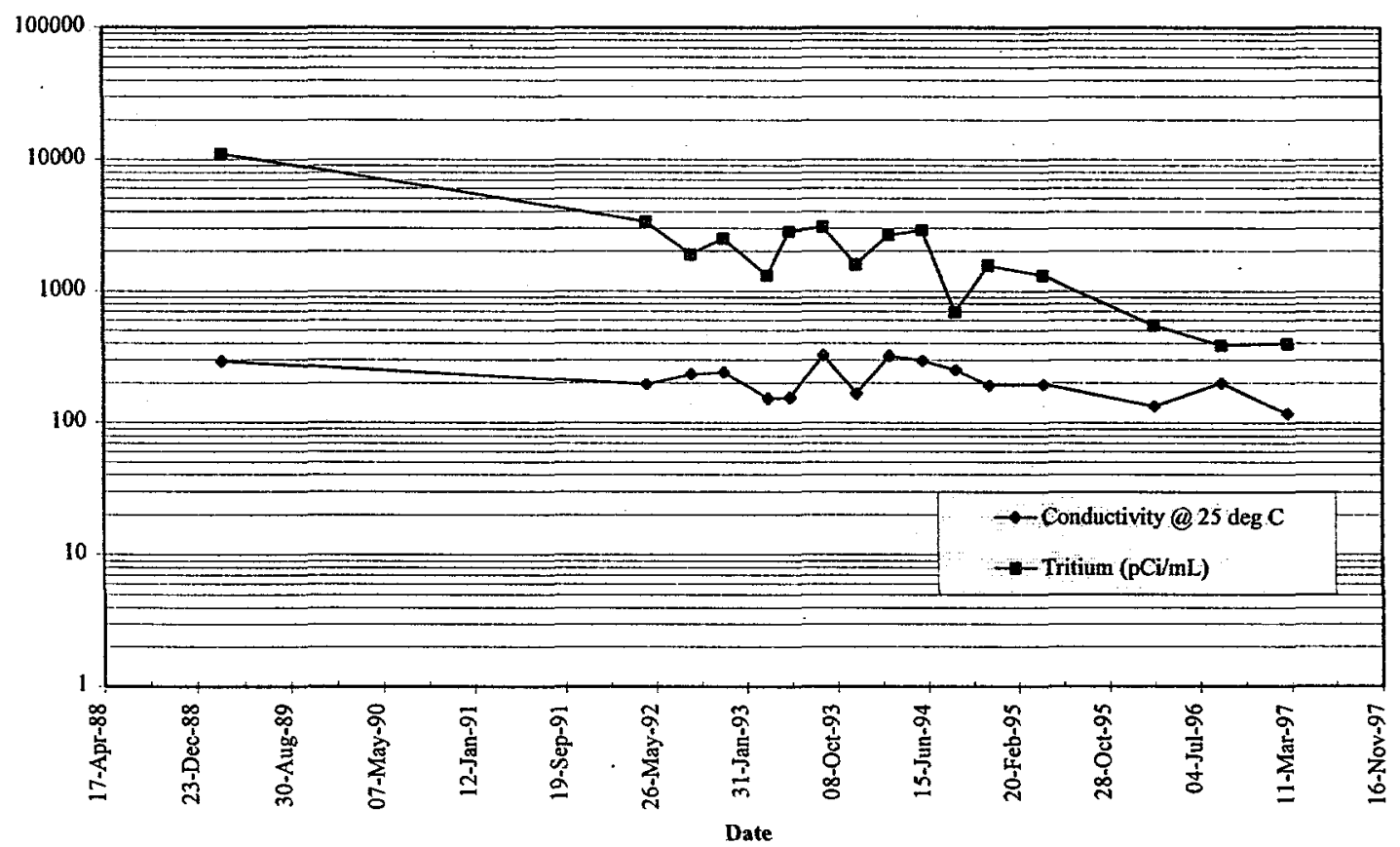


Sample Location HSP008

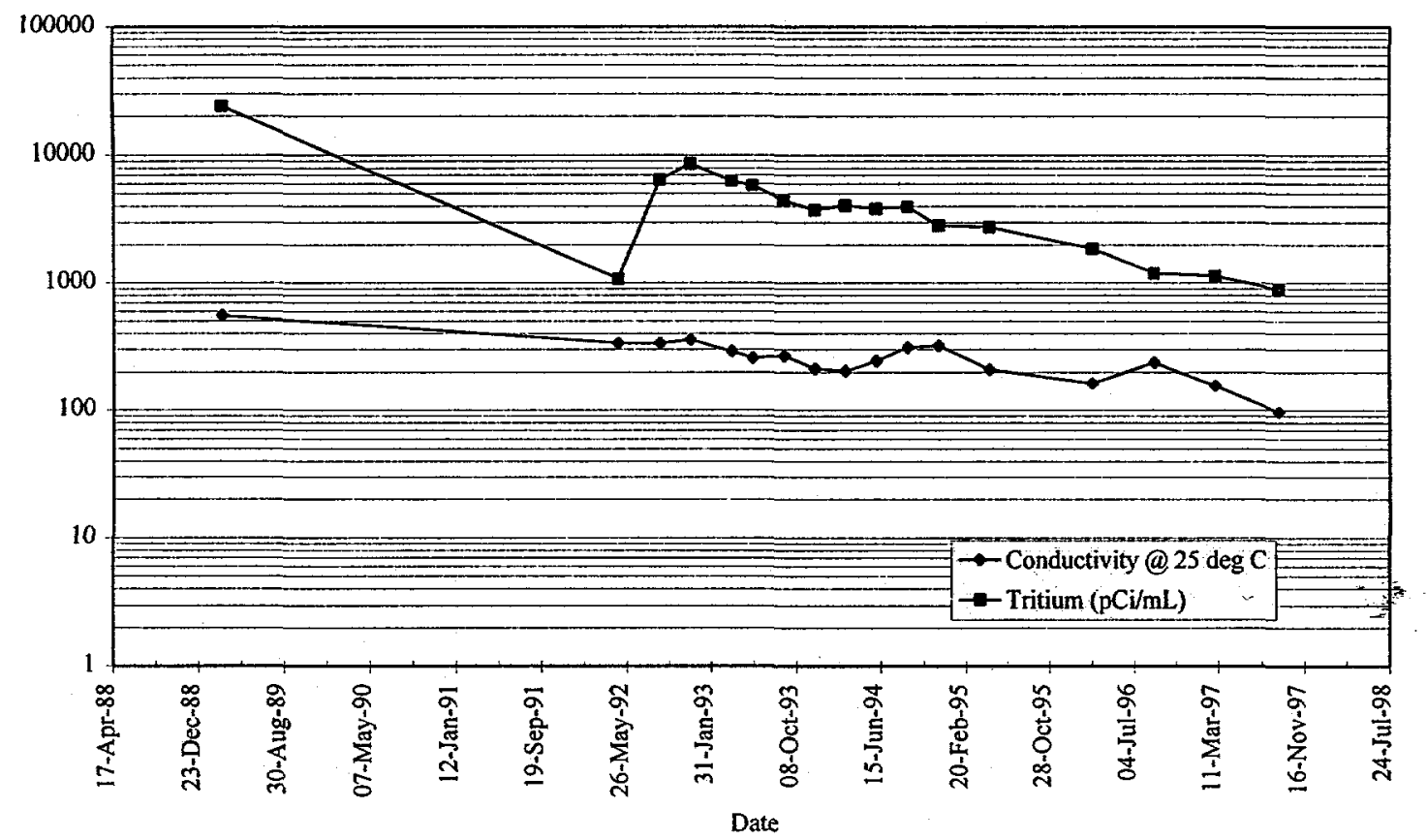

Sample Location HSP011

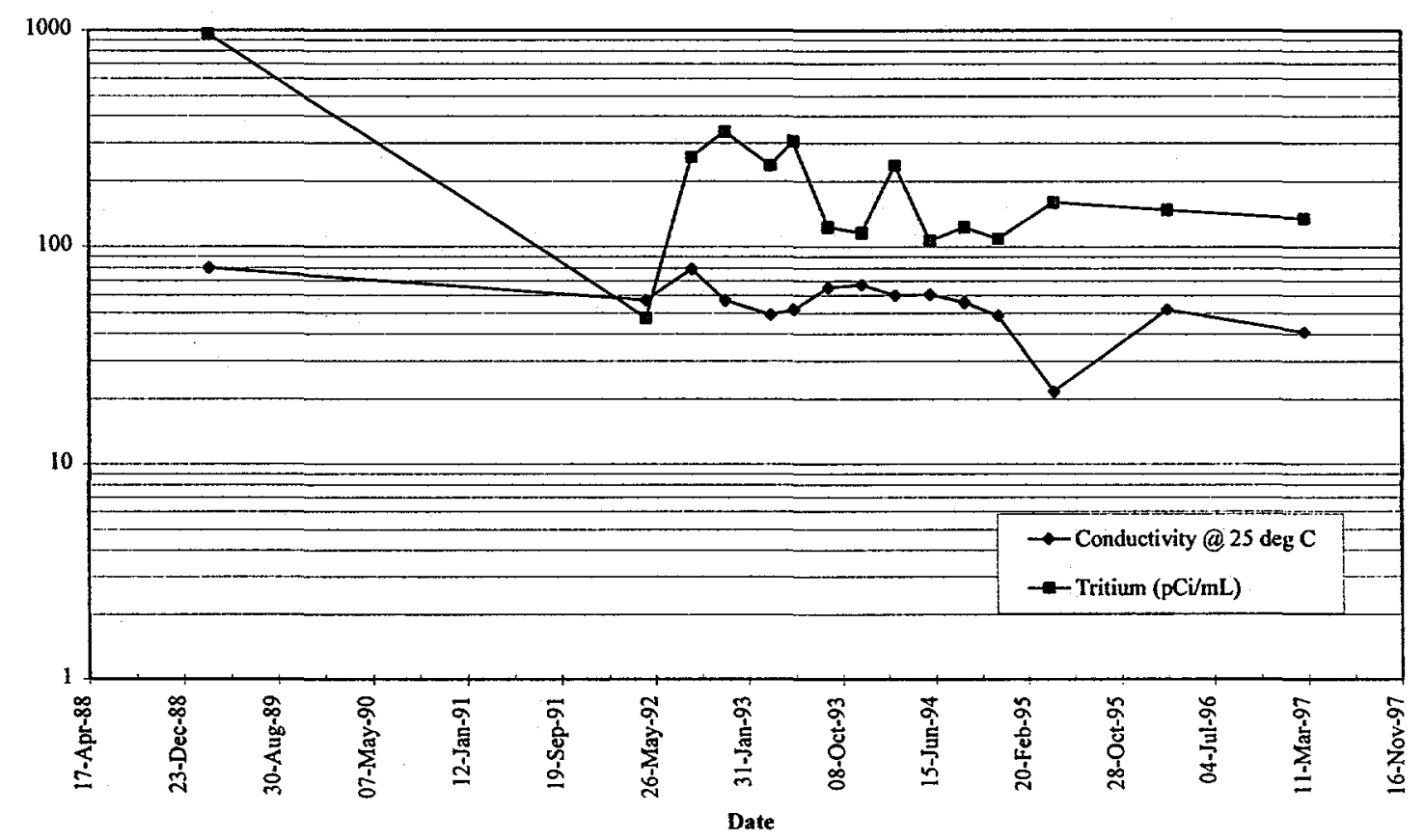


Sample Location HSP013

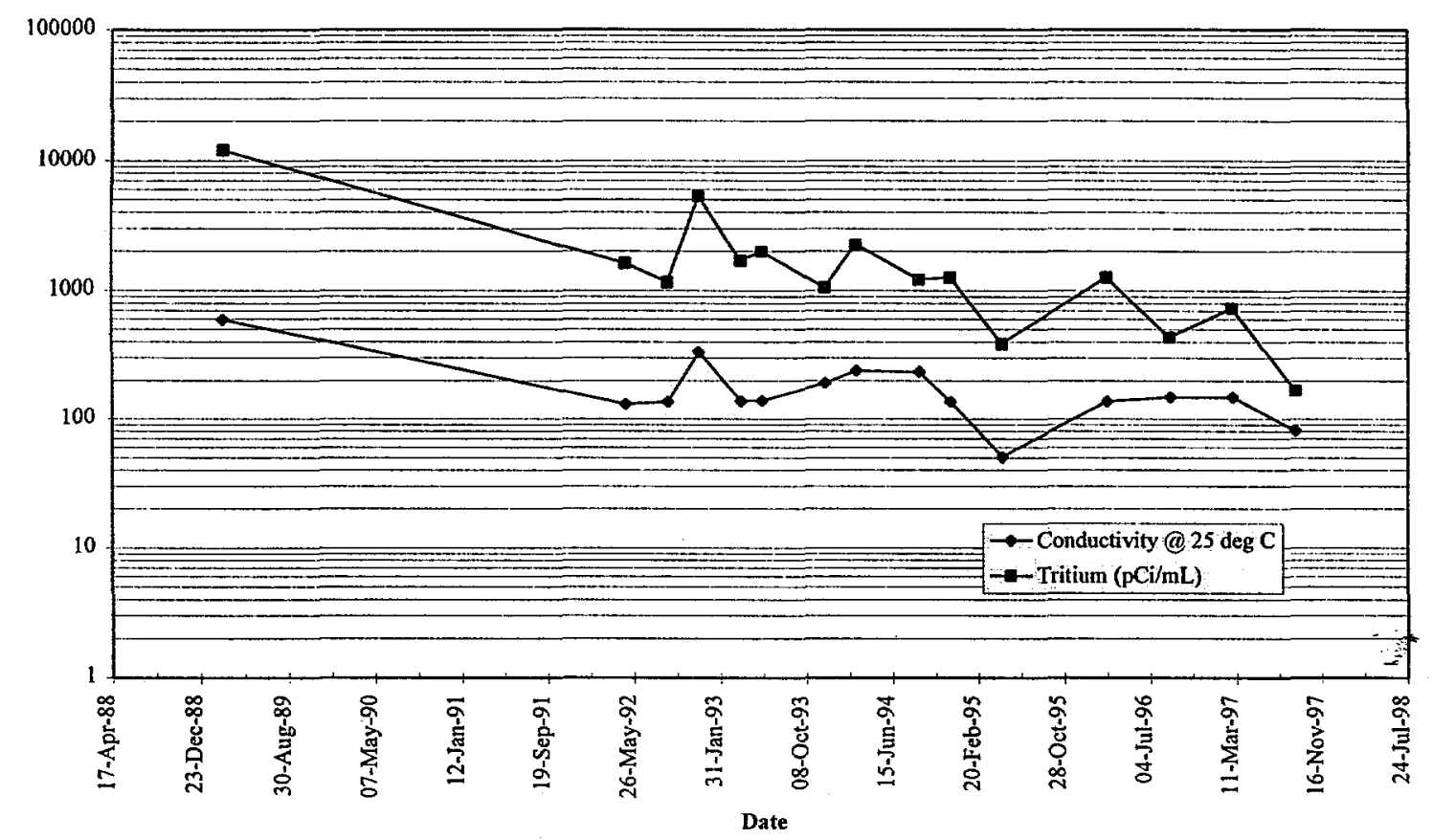

Sample Location HSP015

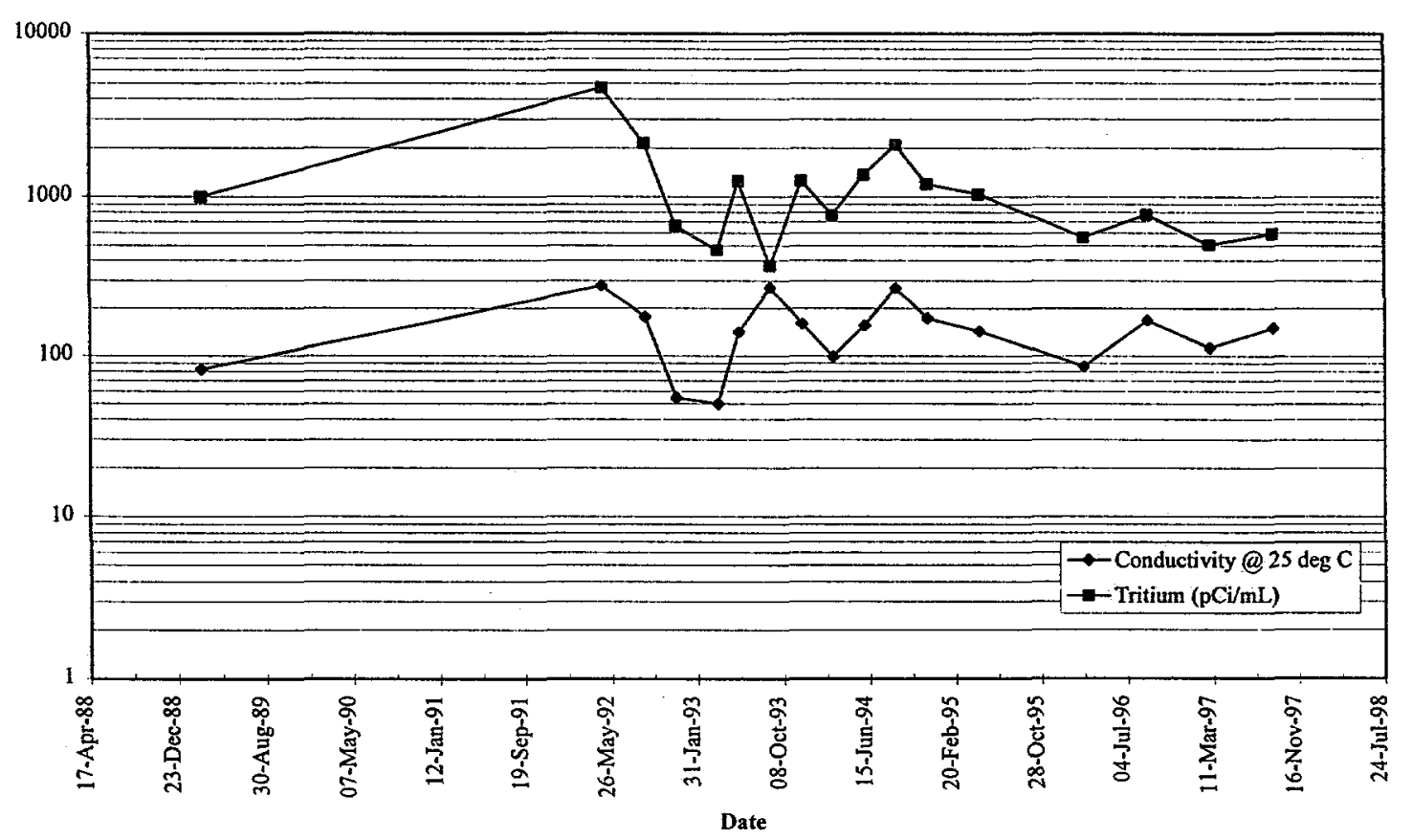




\section{Sample Locaiton HSP020}

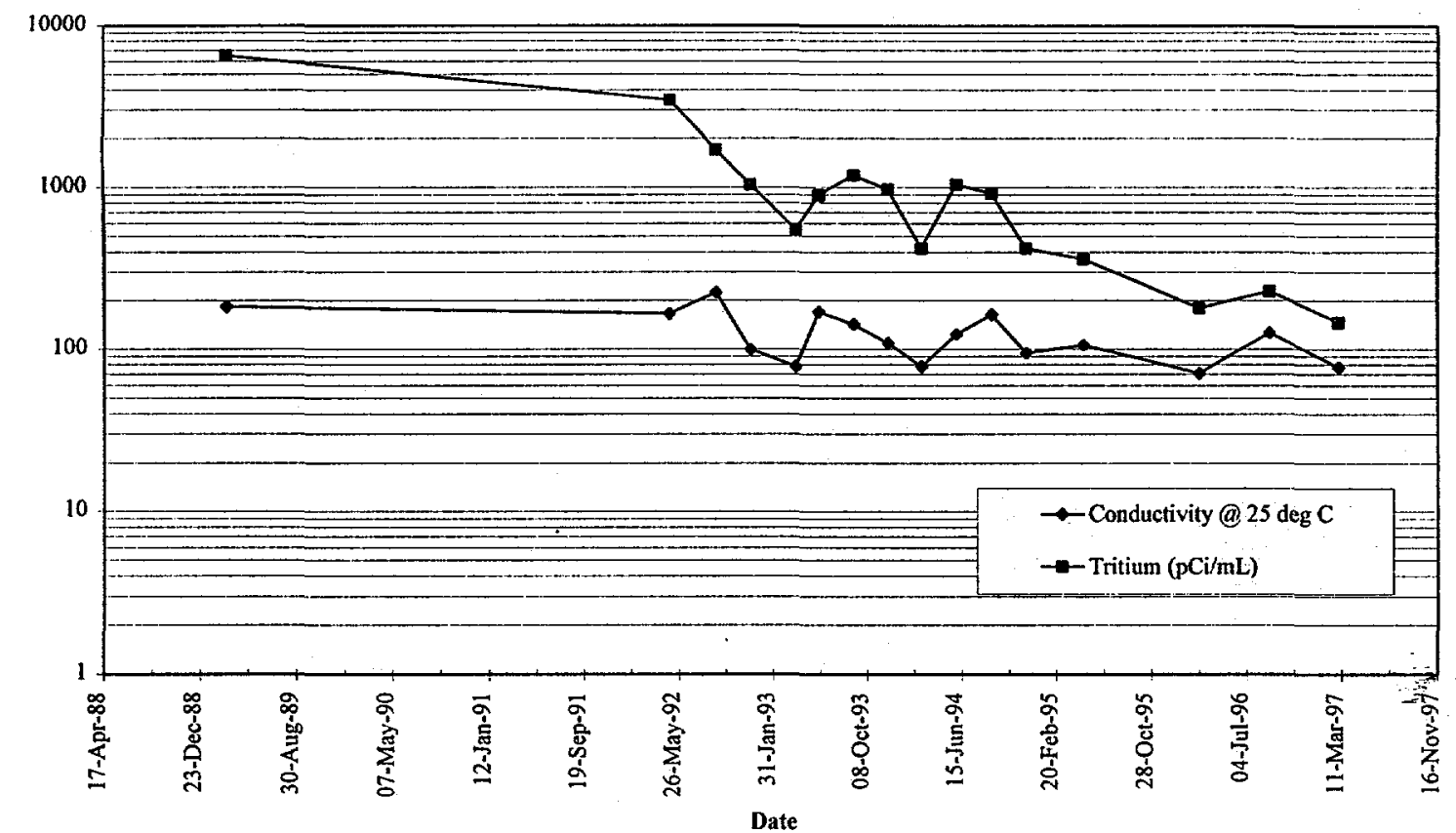

Sample Location HSP025

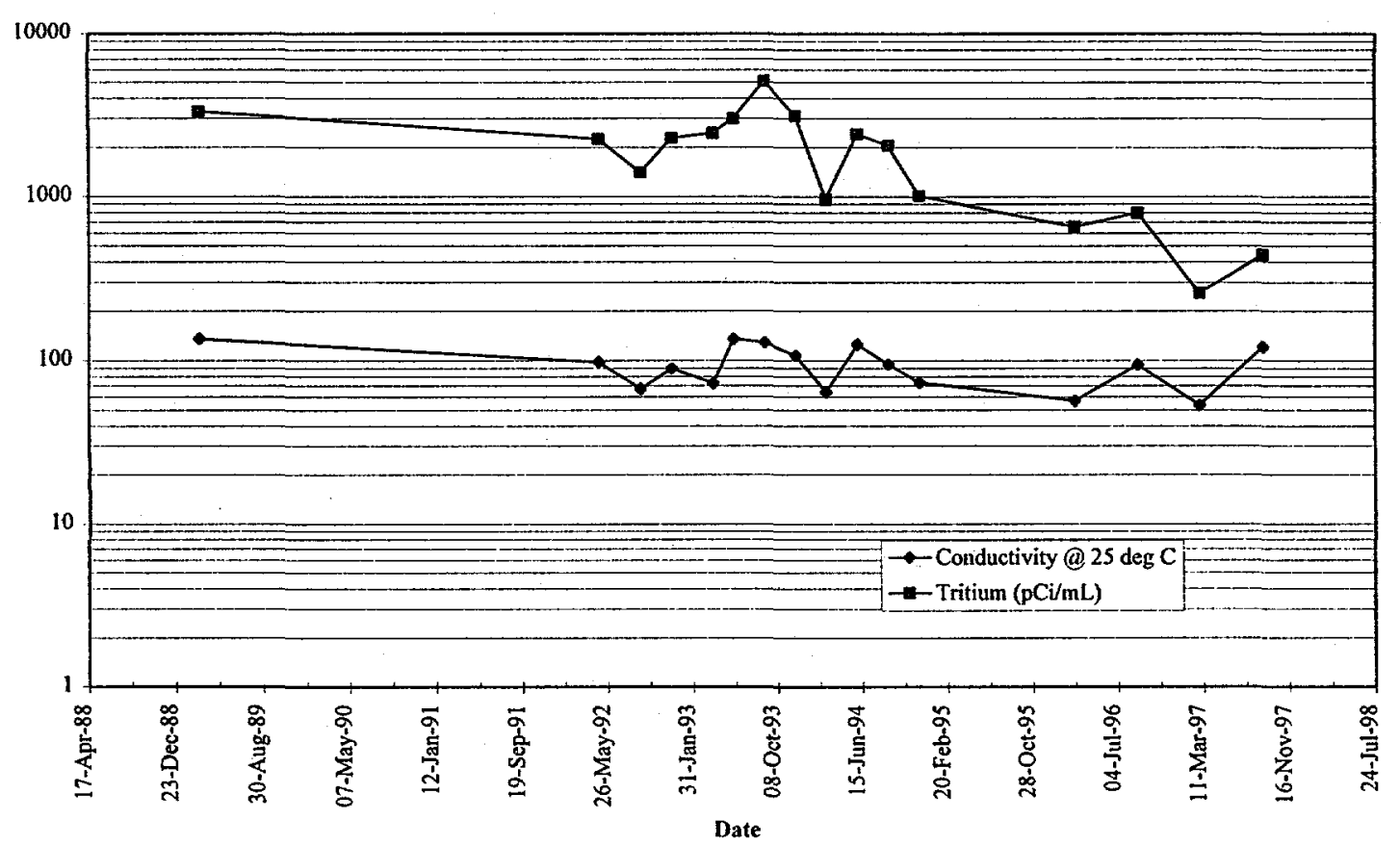


Results of the Tritium Survey of Fourmile Branch and its Seeplines in the F and $H$ Areas of SRS: September 1997 and 1989-1997 Summary

\section{Sample Location HSP029}

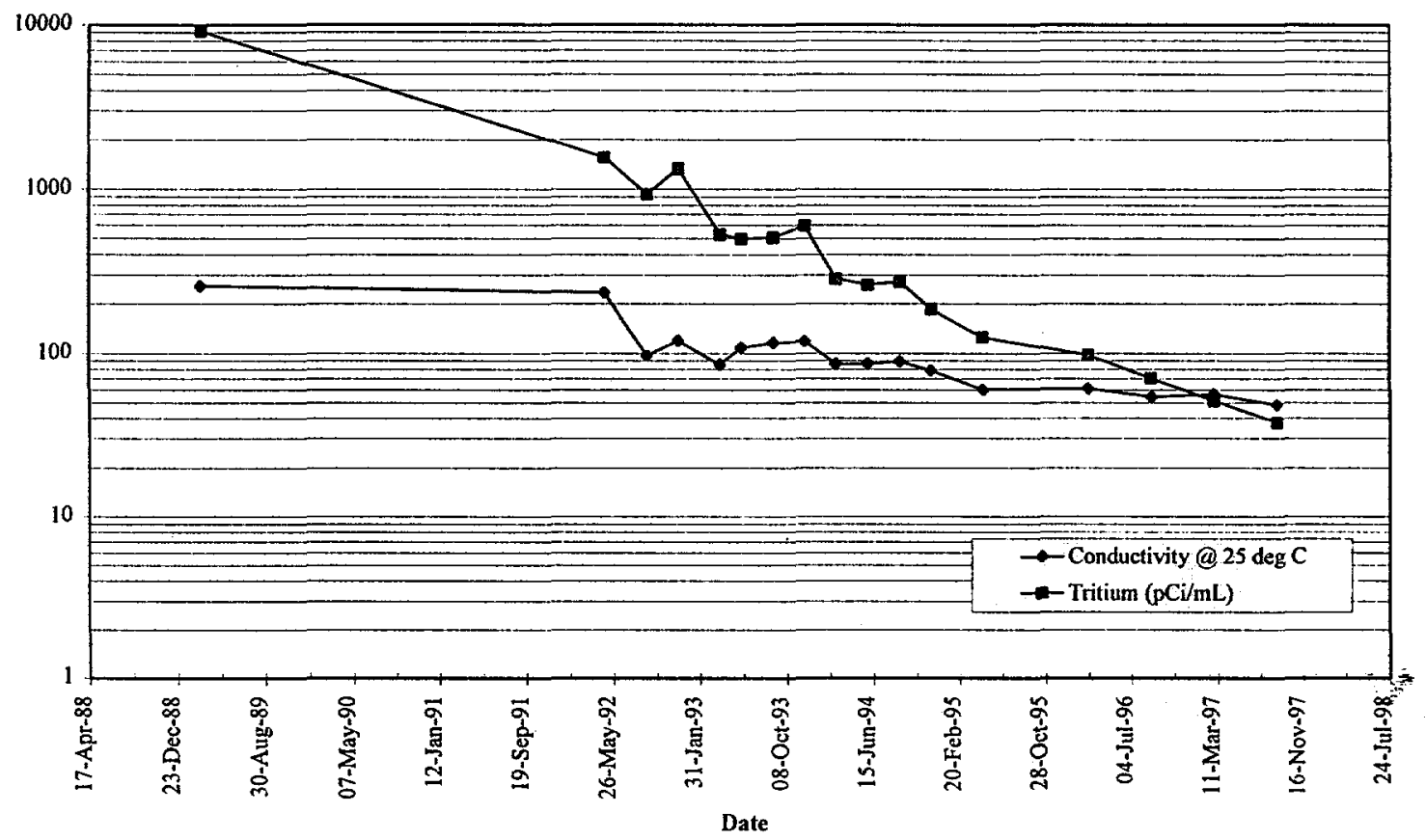

Sample Location HSP034

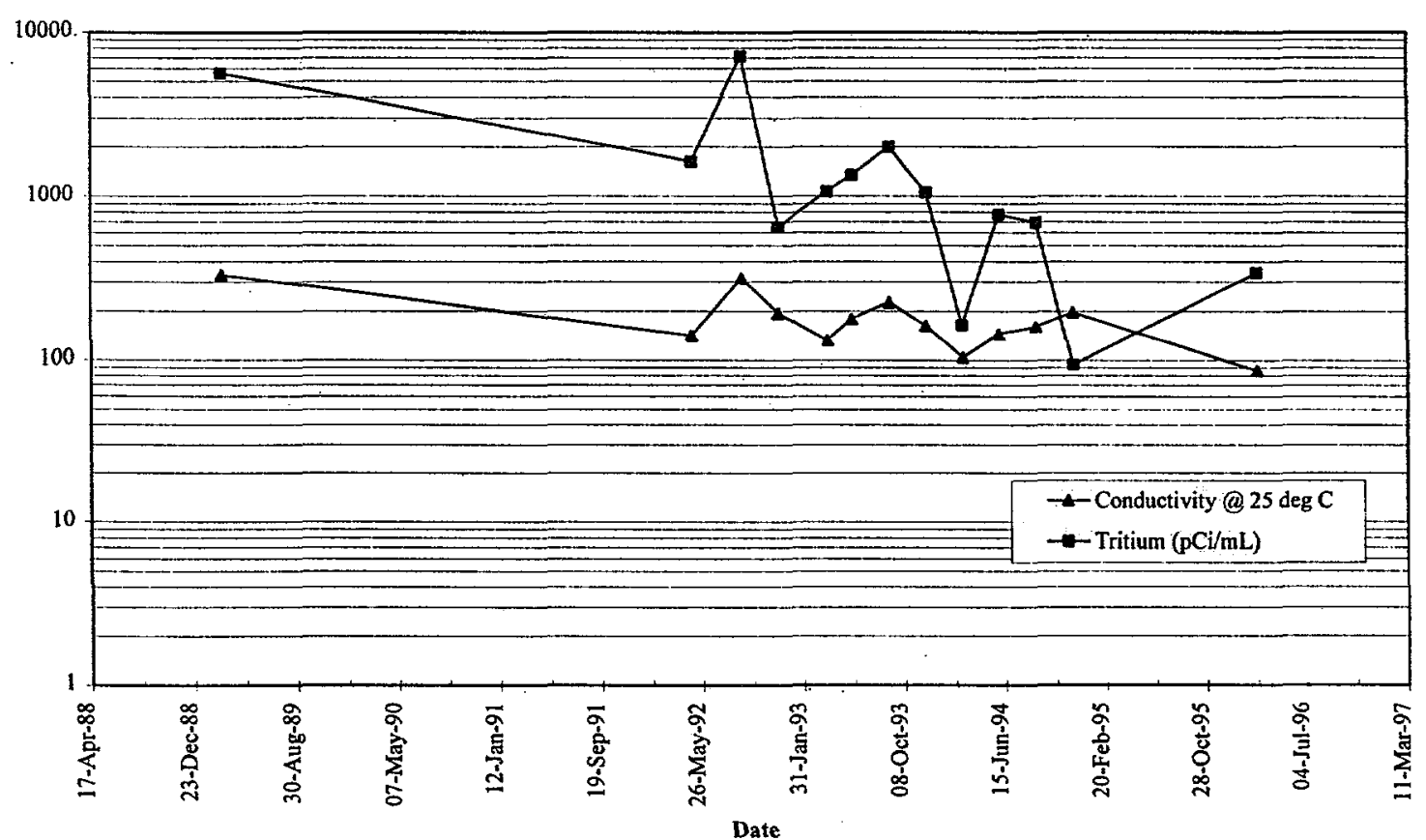




\section{Sample Location HSP038}

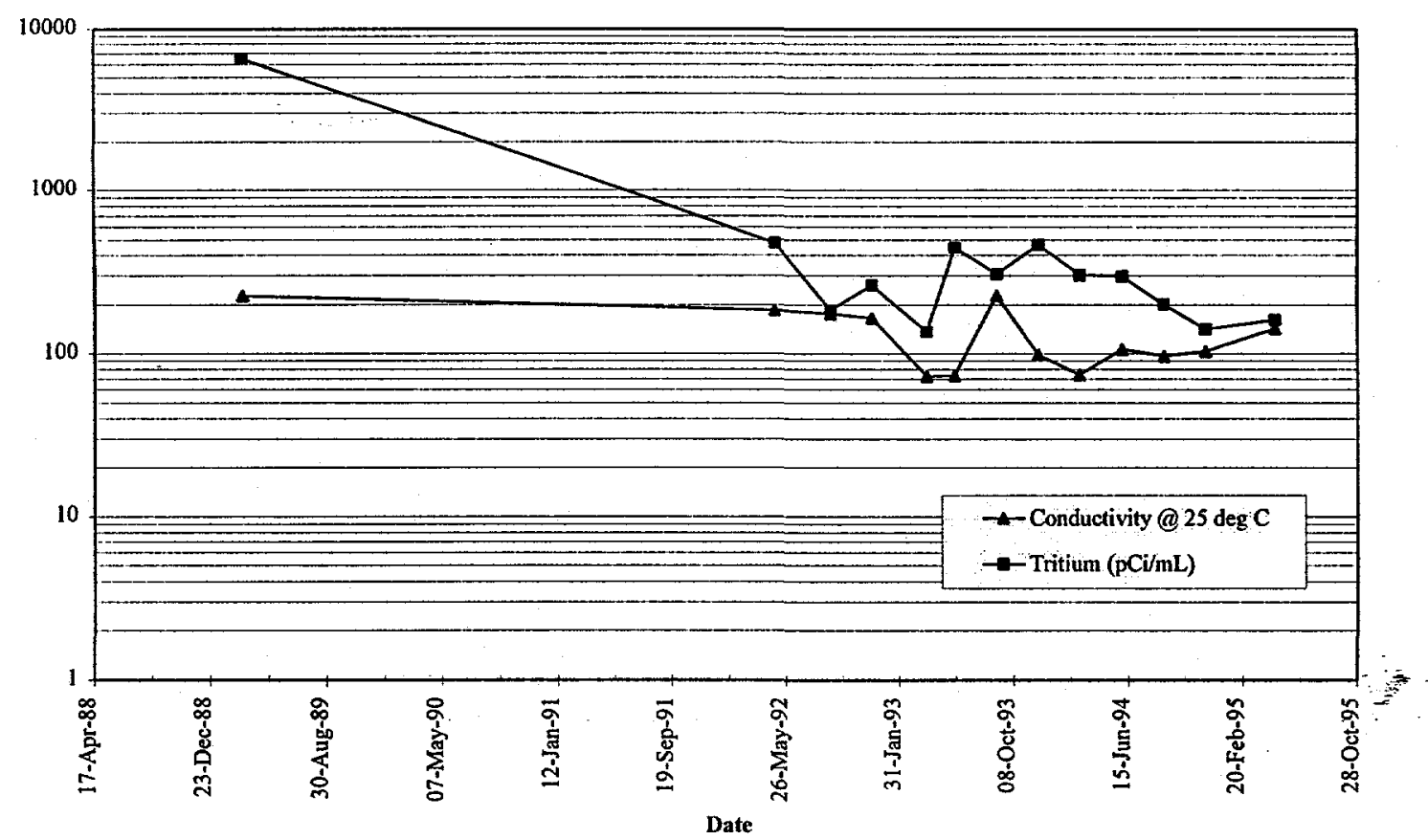

Sample Location HSP043

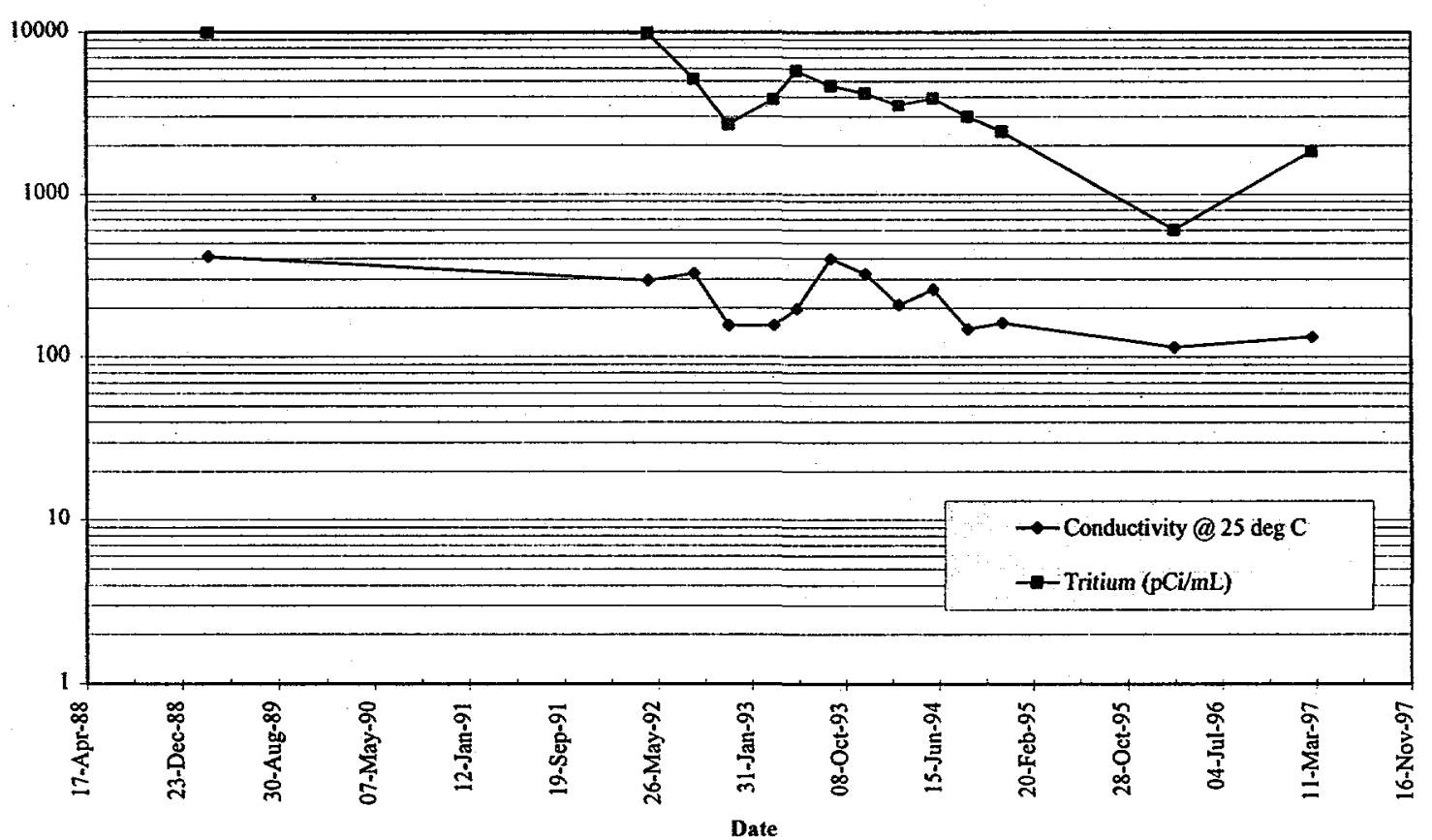


Results of the Tritium Survey of Fourmile Branch and its Seeplines in the F and $H$ Areas of SRS: September 1997 and 1989-1997 Summary

\section{Sample Location HSP046}

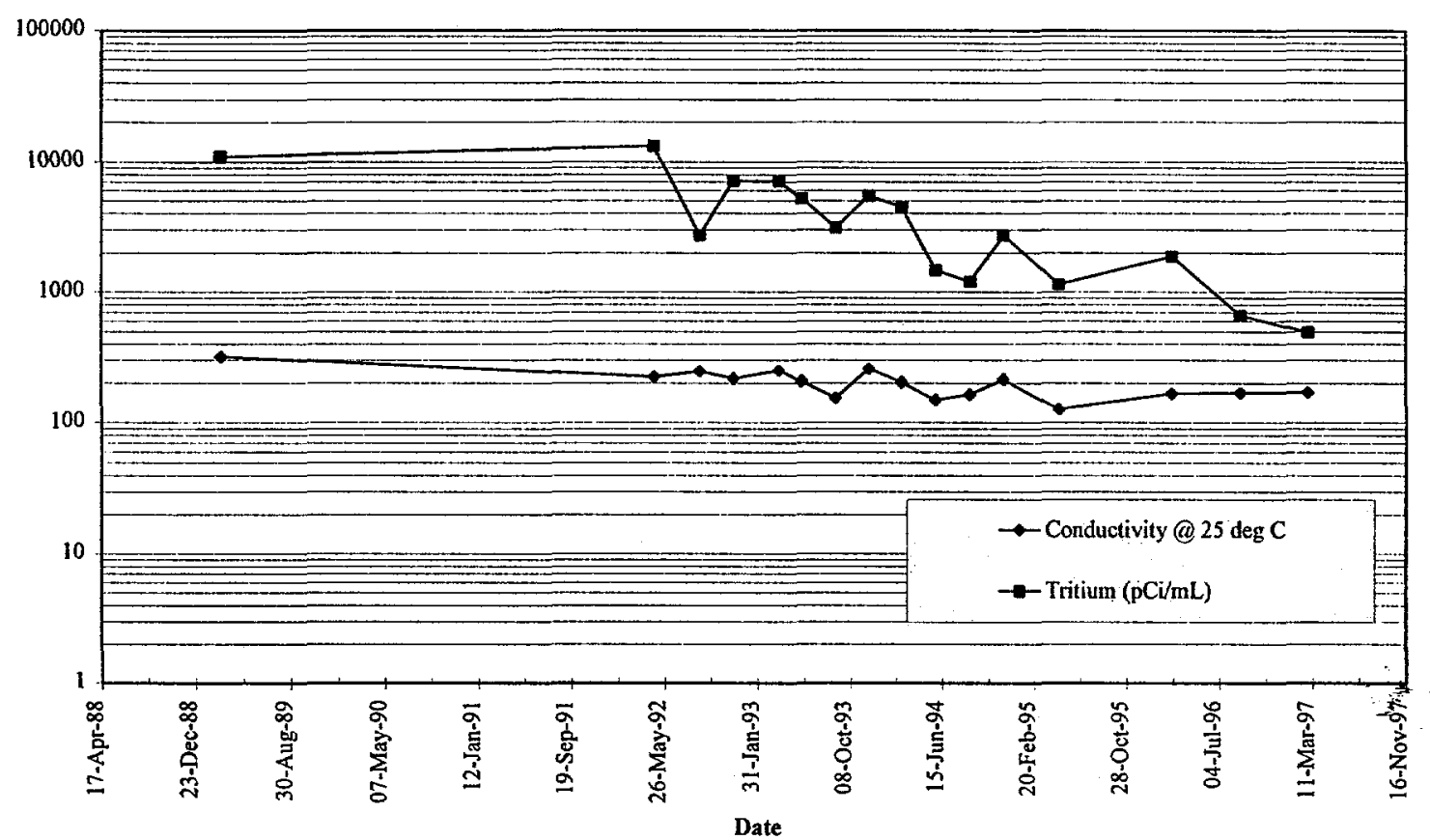

Sample Location HSP049

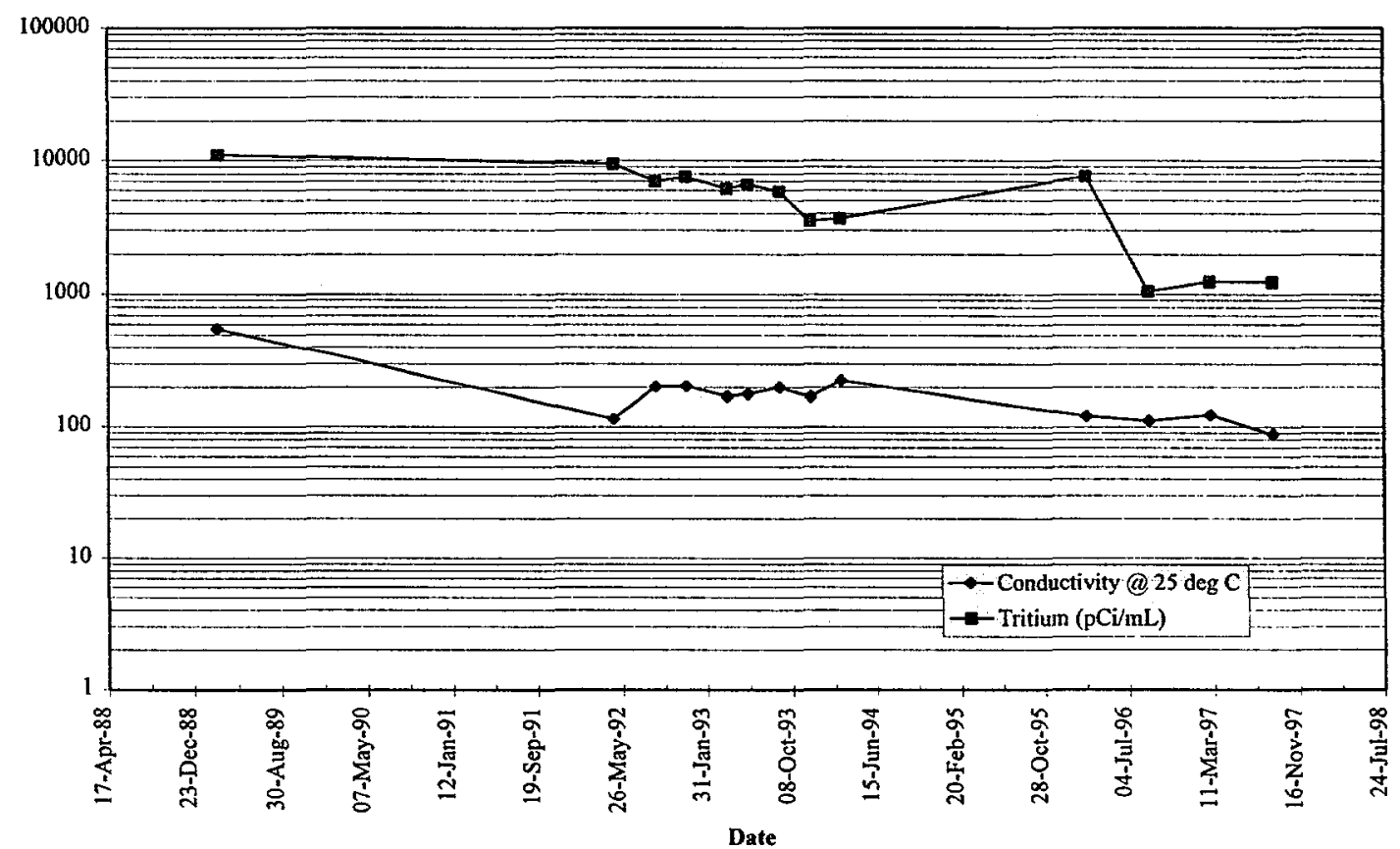


Sample Location HSP052

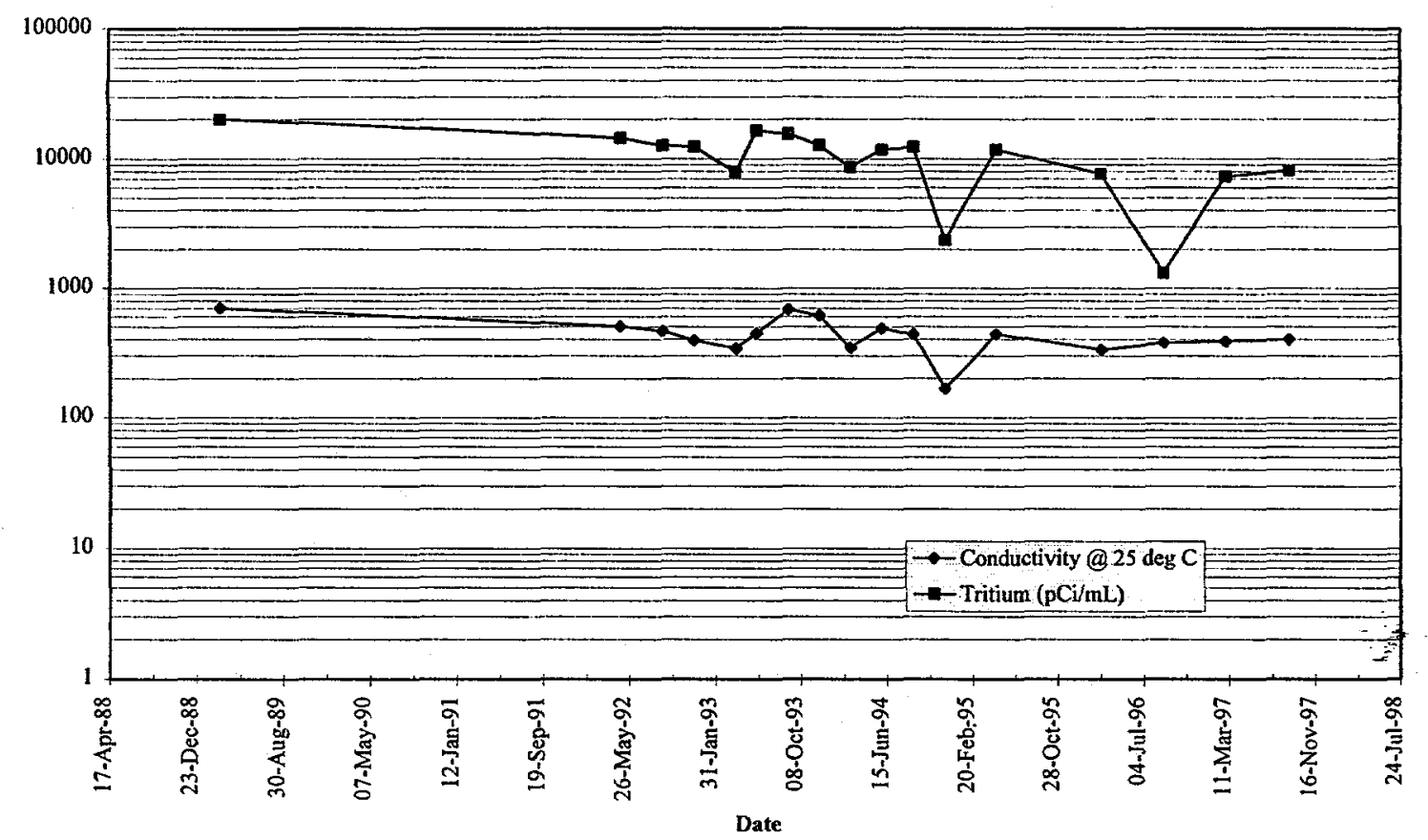

Sample Location HSP057

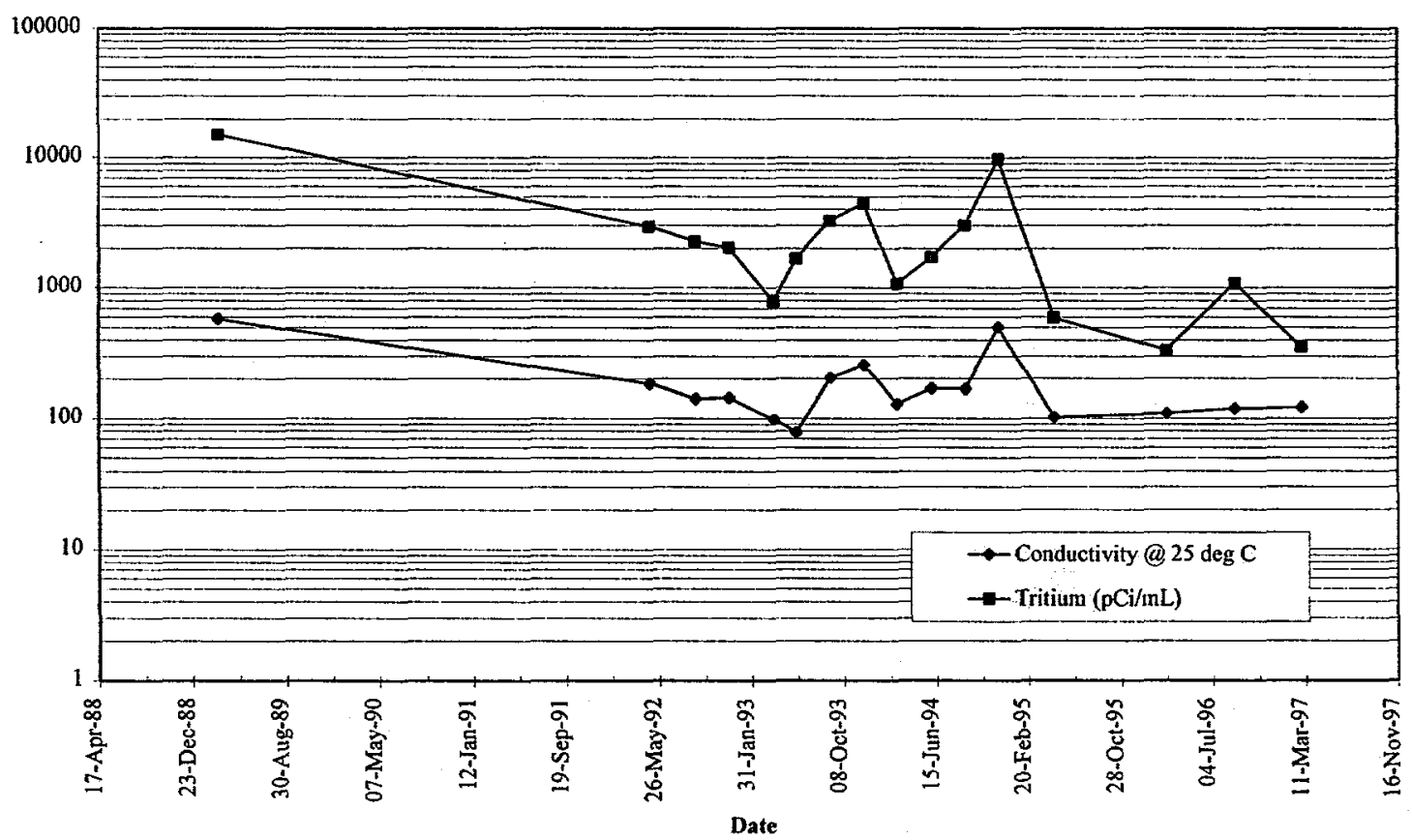


Results of the Tritium Survey of Fourmile Branch and its Seeplines in the F and H Areas of SRS: September 1997 and 1989-1997 Summary

Sample Location HSP060

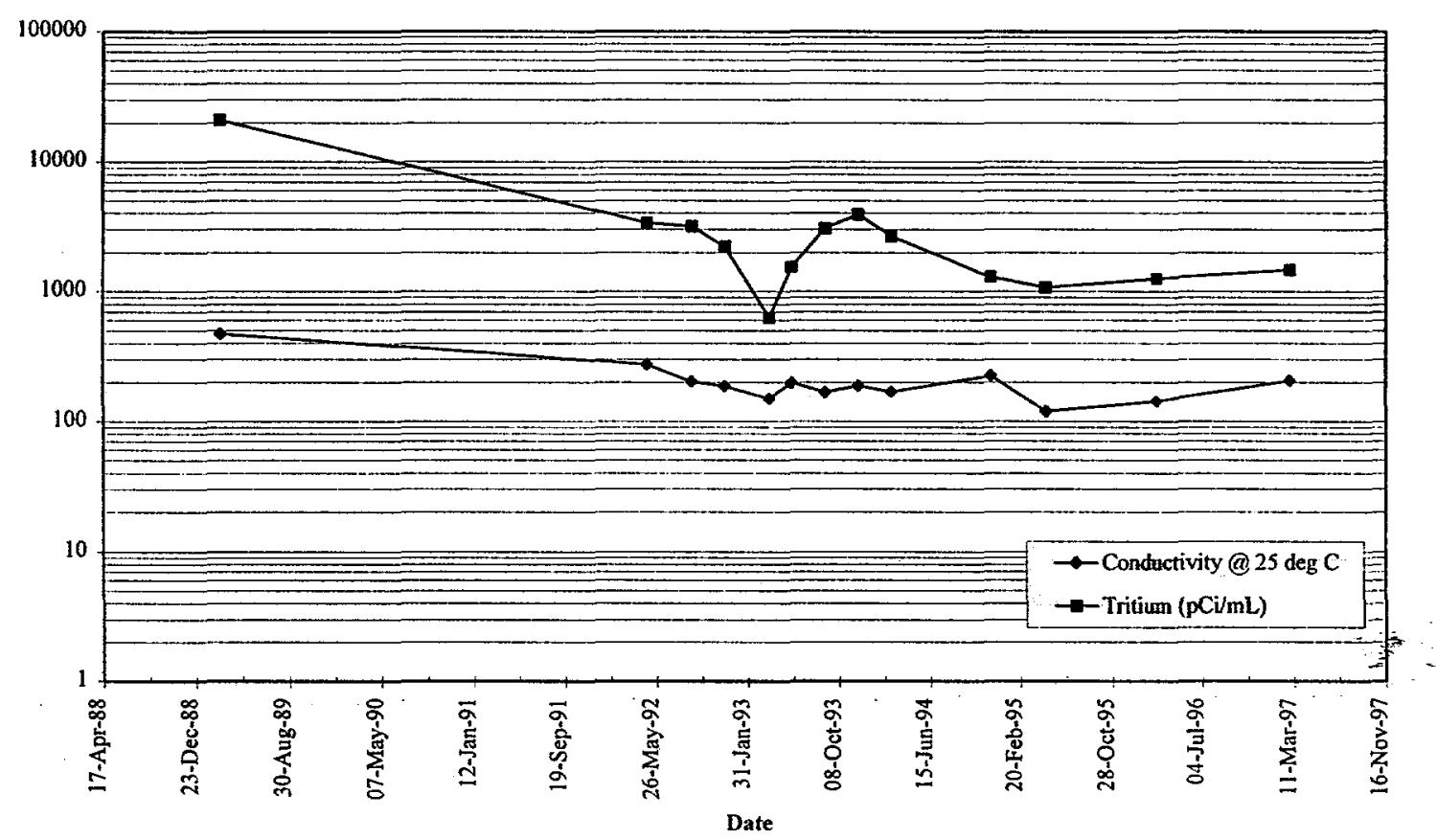

Sample Location HSP064

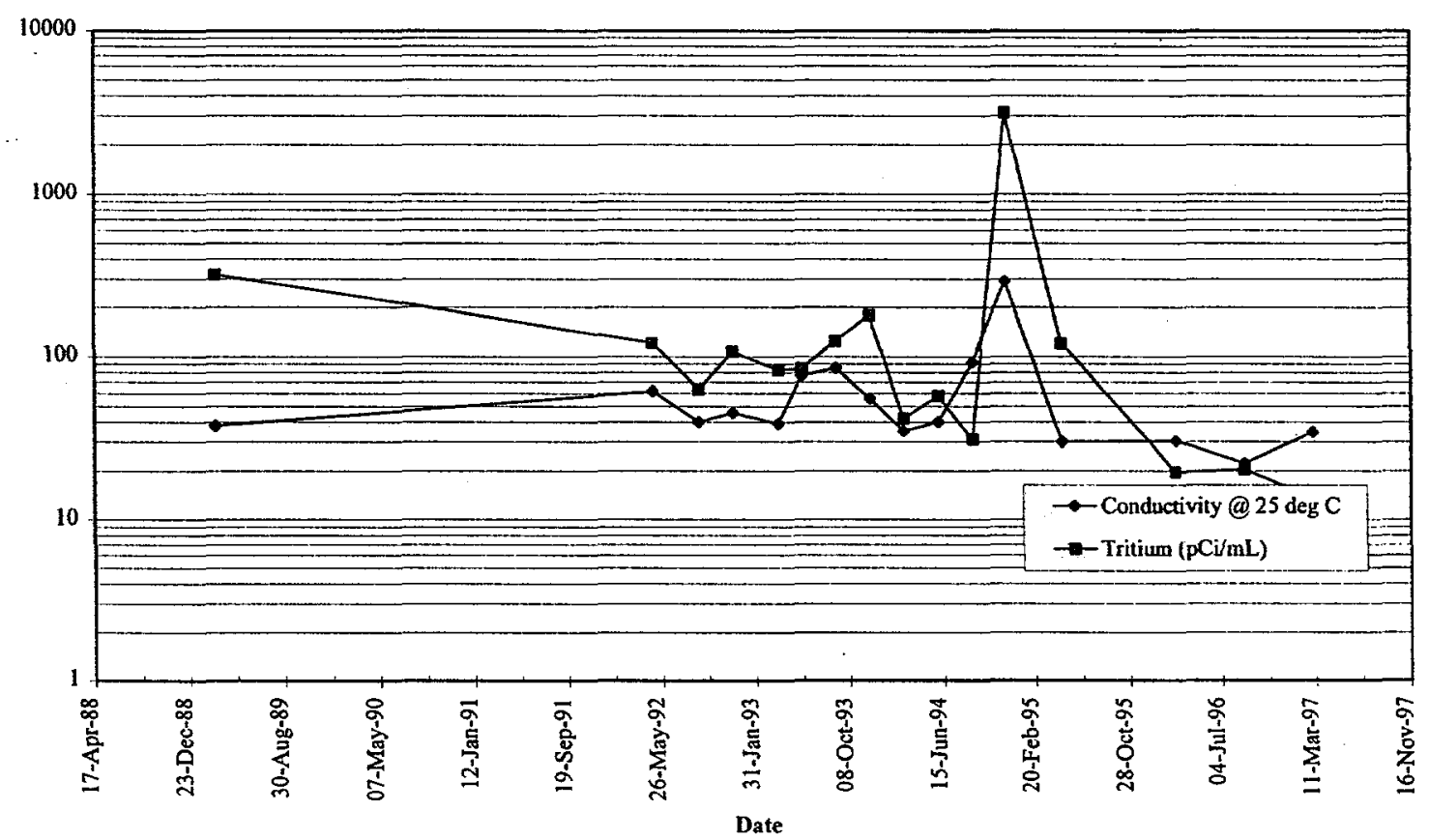




\section{Sample Location HSP071}

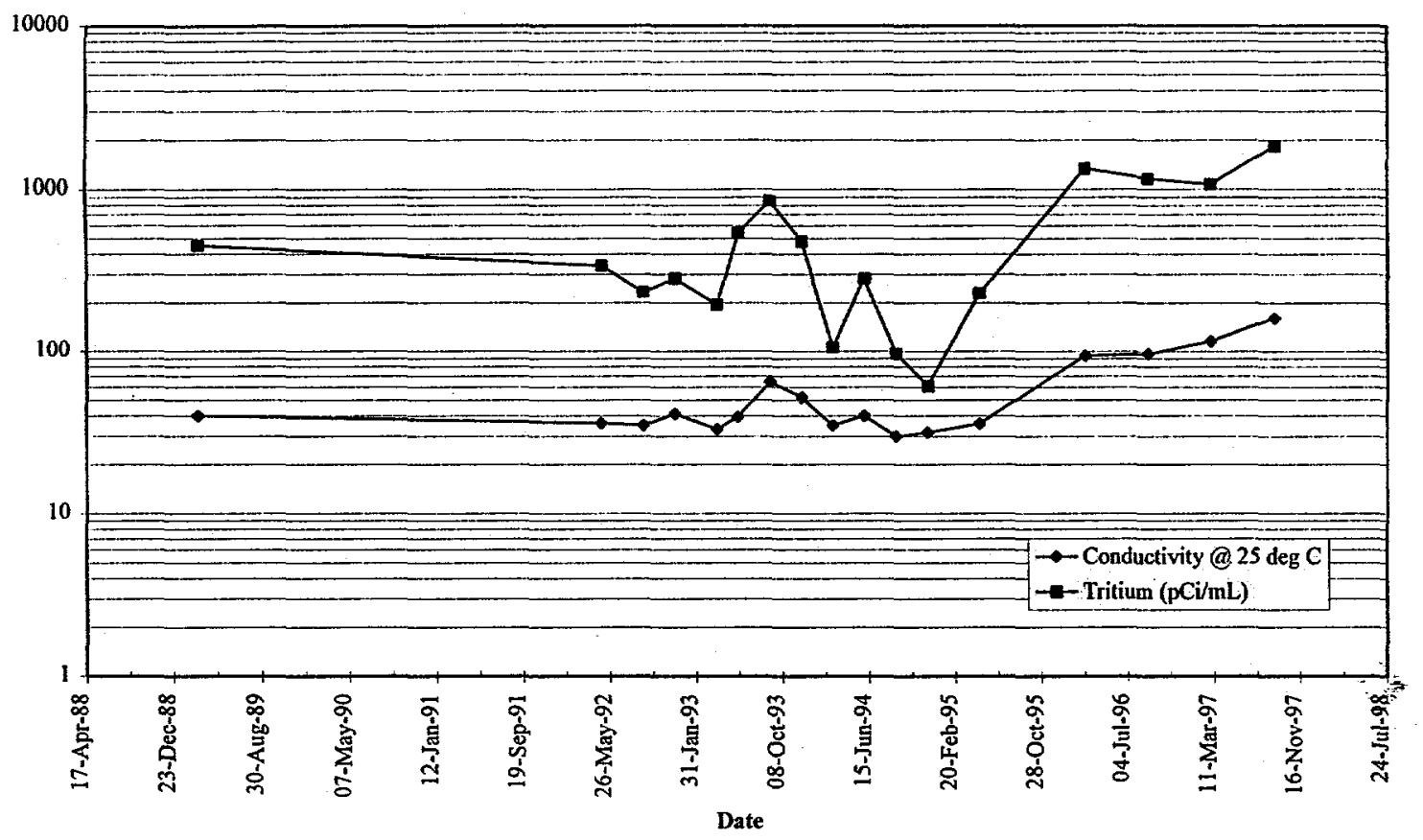

Sample Location HSP076

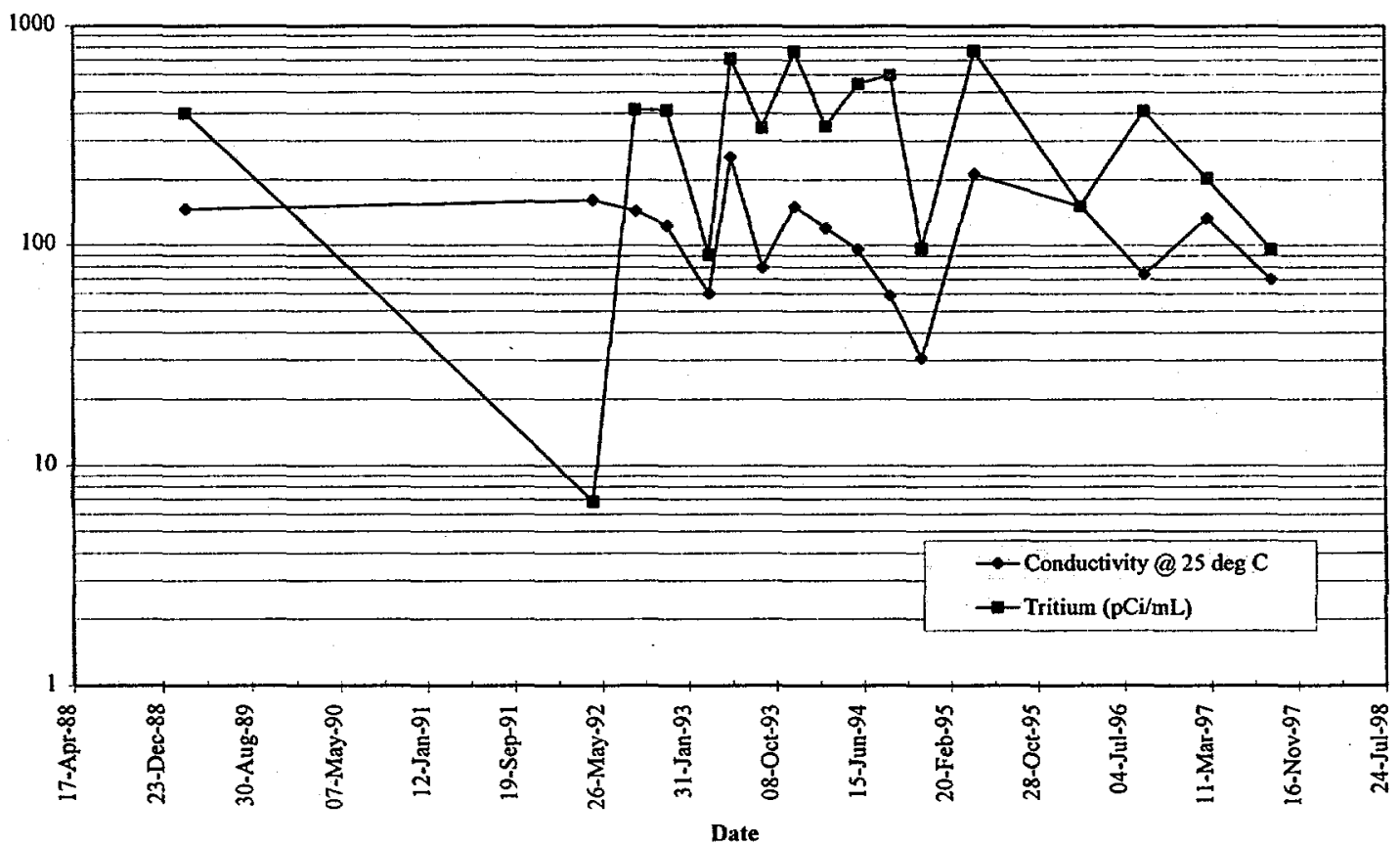


Results of the Tritium Survey of Fourmile Branch and its Seeplines in the F and H Areas of SRS: September 1997 and 1989-1997 Summary

\section{Sample Location HSP097}

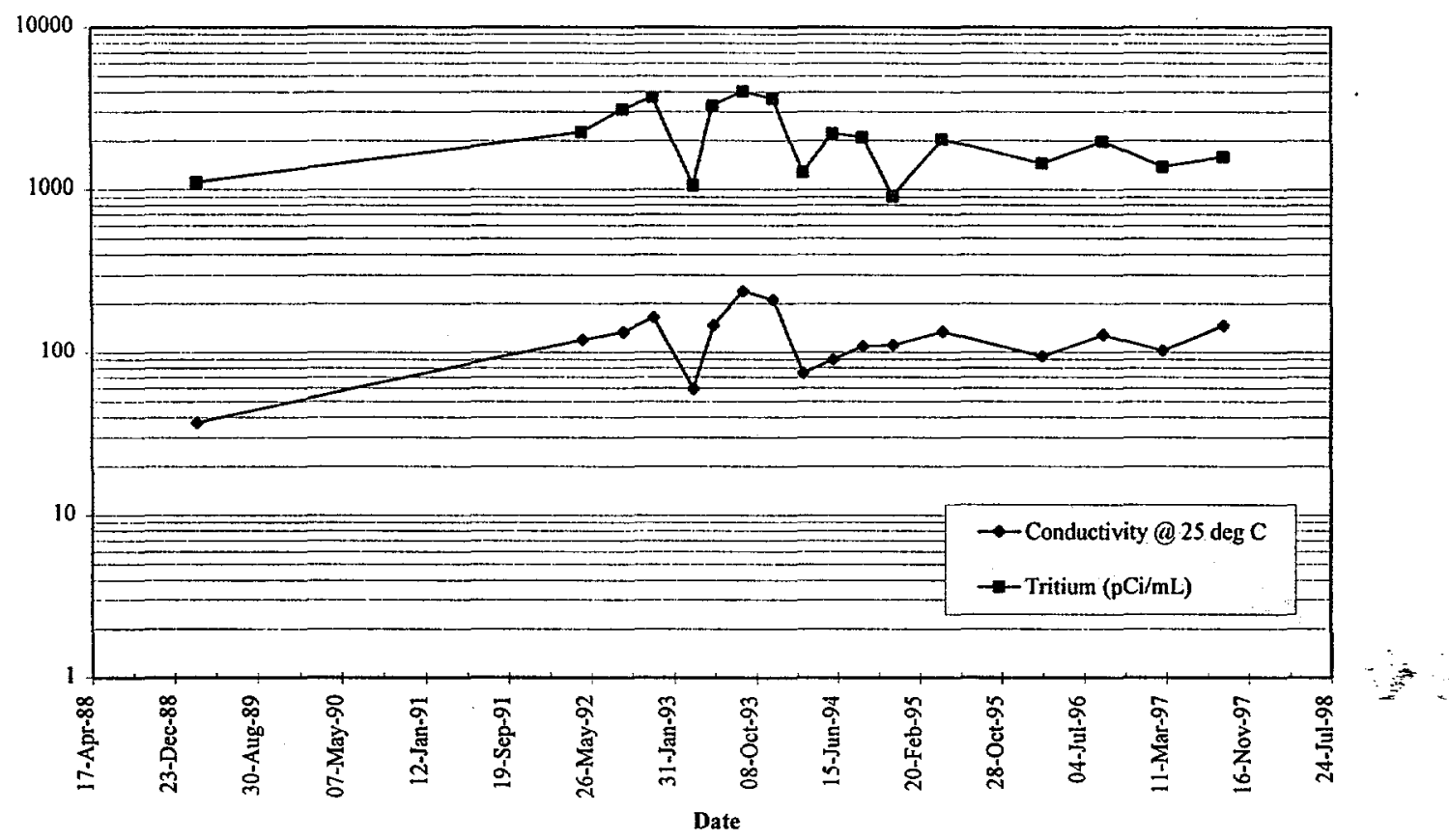

\section{Sample Location HSP103}

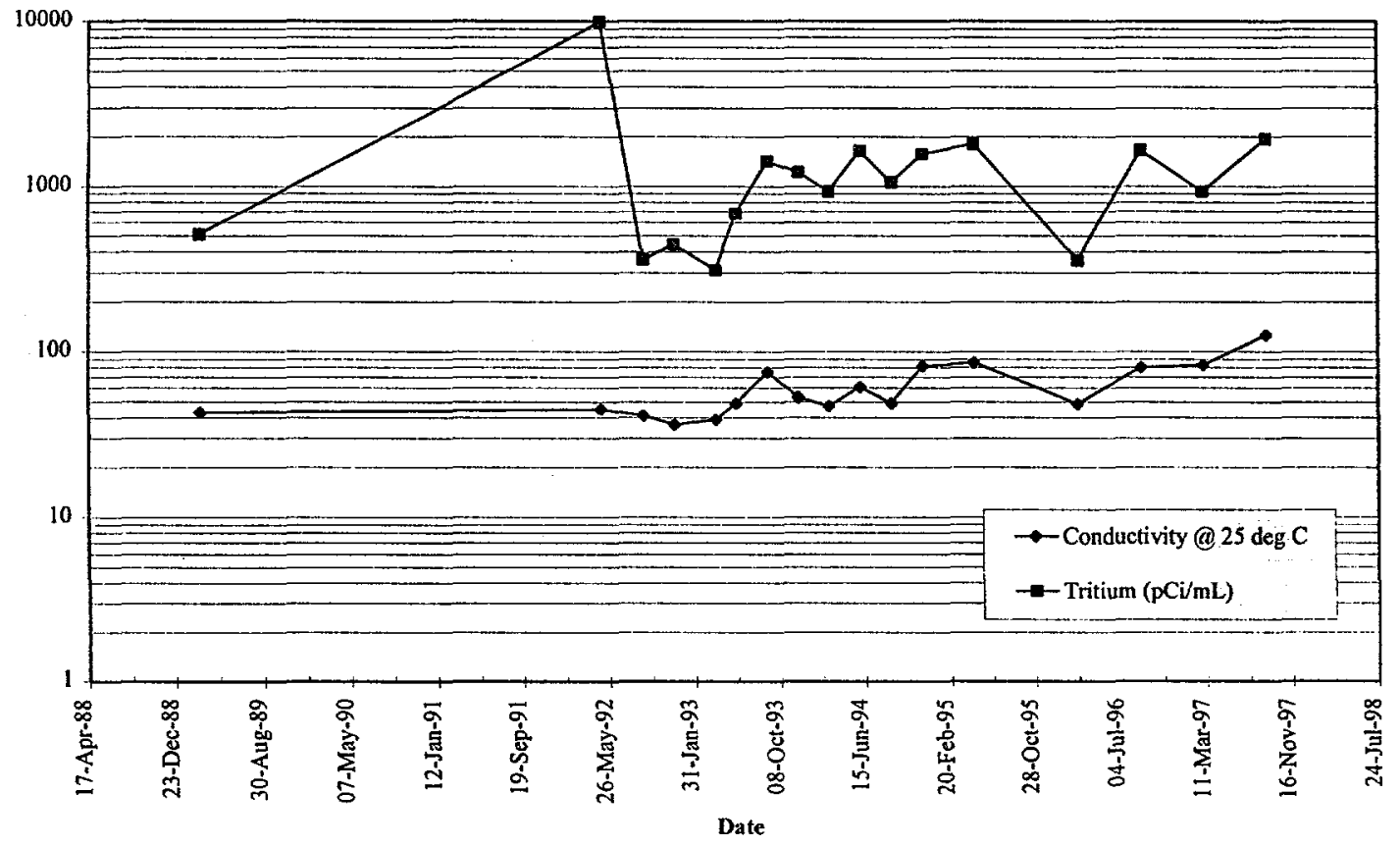




\title{
Appendix C
}

\author{
643-E Seepline
}

Tritium Concentrations and Conductivity Plotted by Sampling Location, 1992-1997 
Results of the Tritium Survey of Fourmile Branch and its Seeplines in the F and $H$ Areas of SRS: September 1997 and 1989-1997 Summary

\section{Sample Location FHB001}

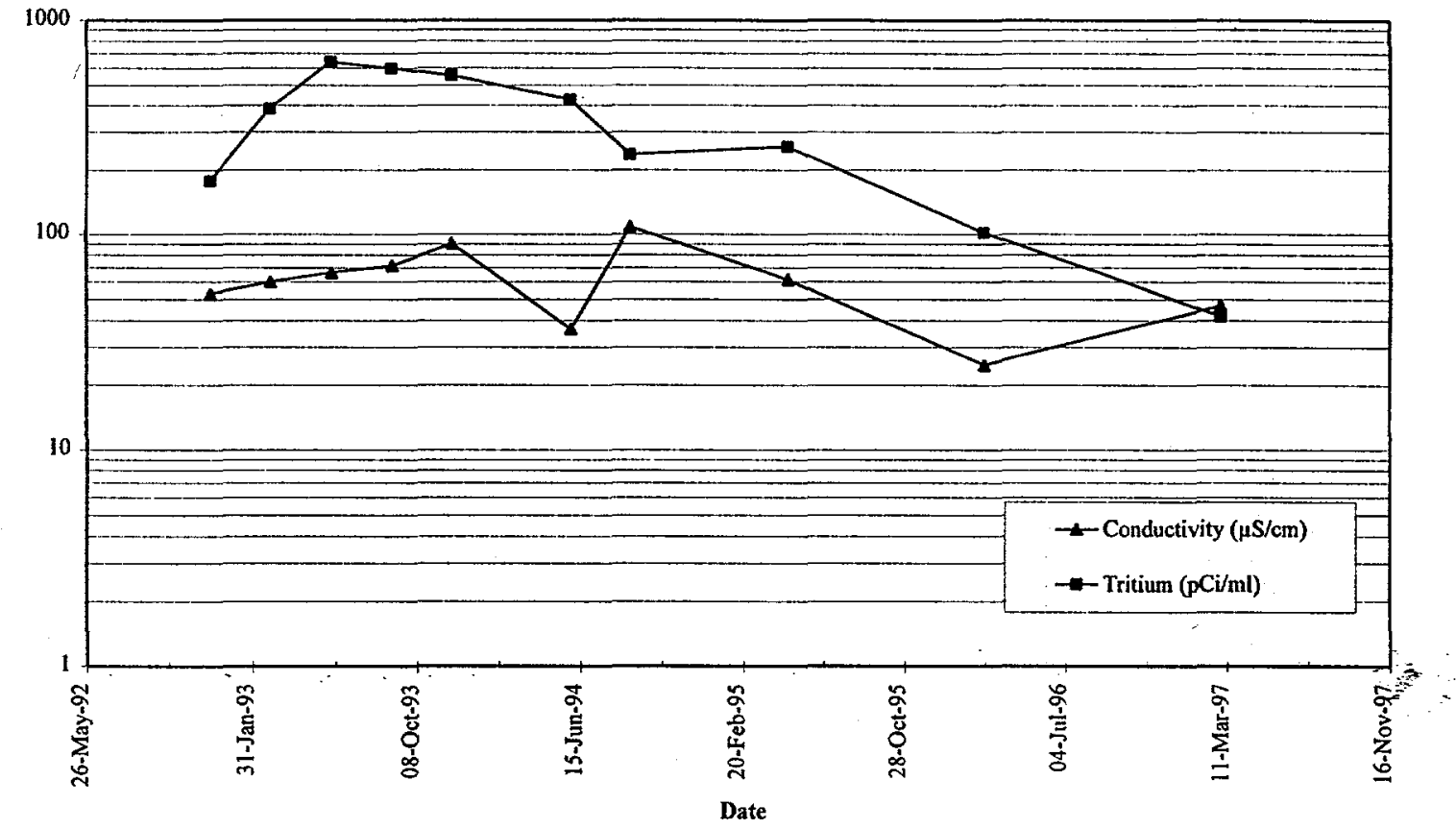

Sample Location FHB002

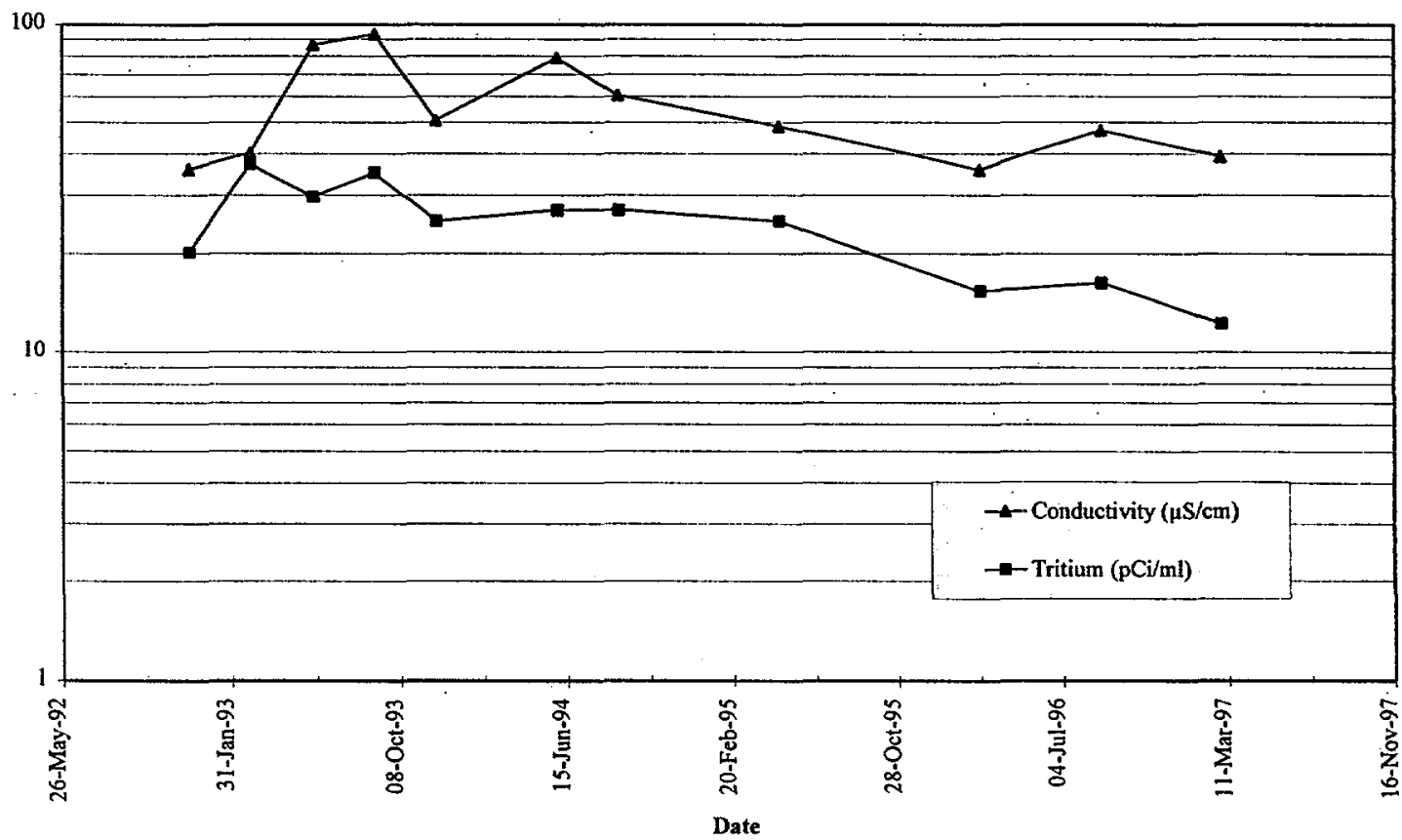




\section{Sample Location FHB003}

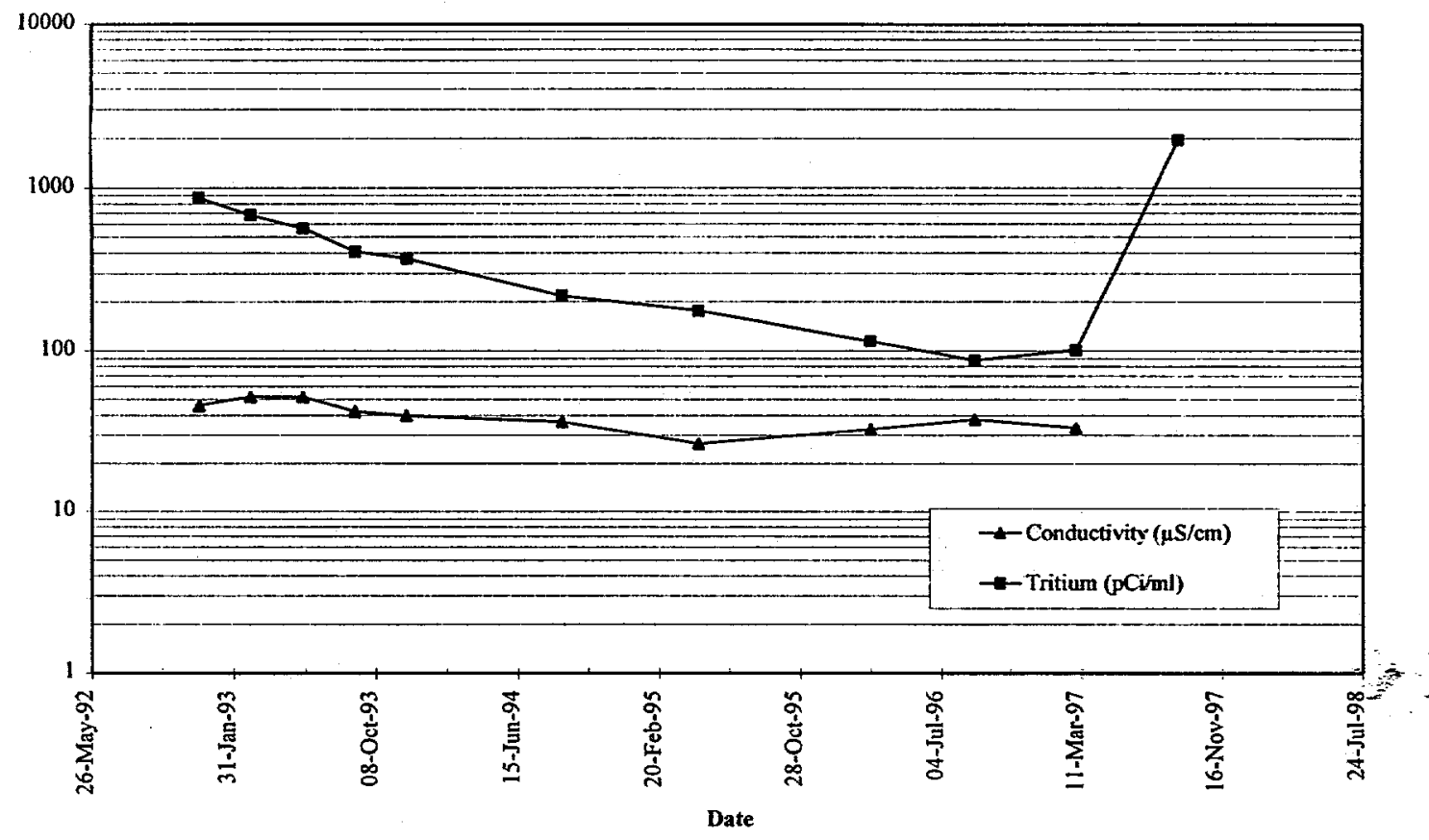

Sample Location FHB004

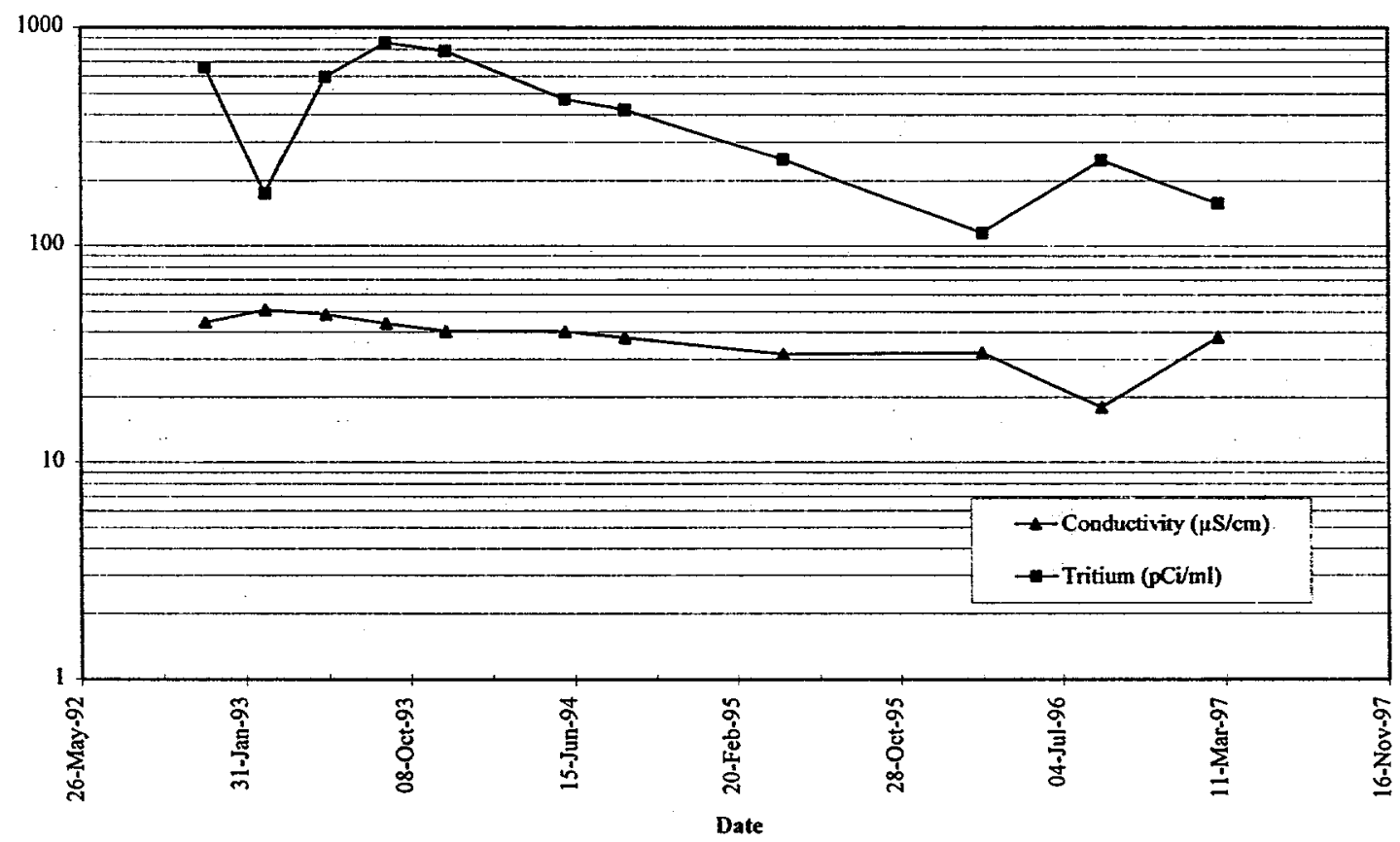


Results of the Tritium Survey of Fourmile Branch and its Seeplines in the F and H Areas of SRS: September 1997 and 1989-1997 Summary

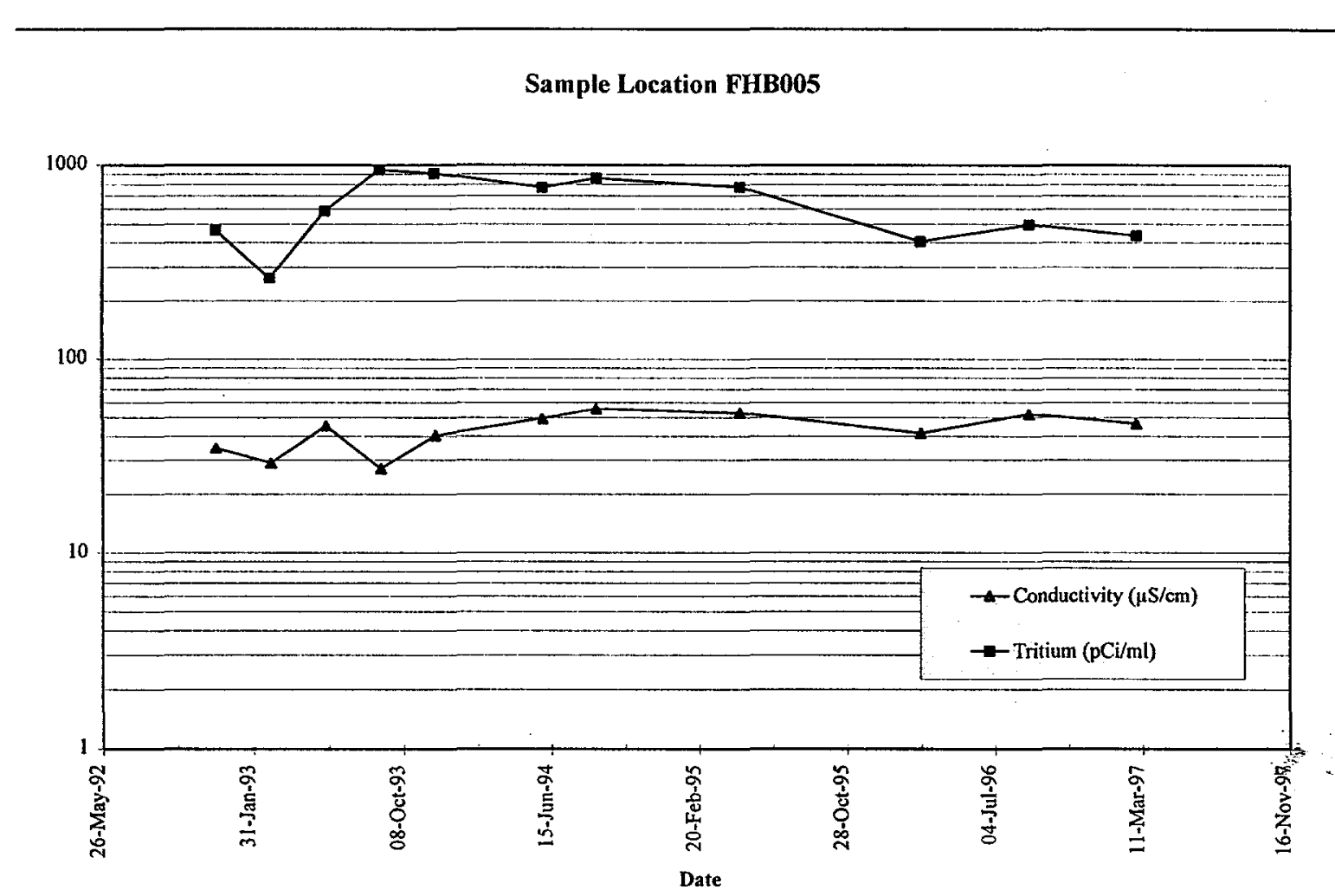

\section{Sample Location FHB006}

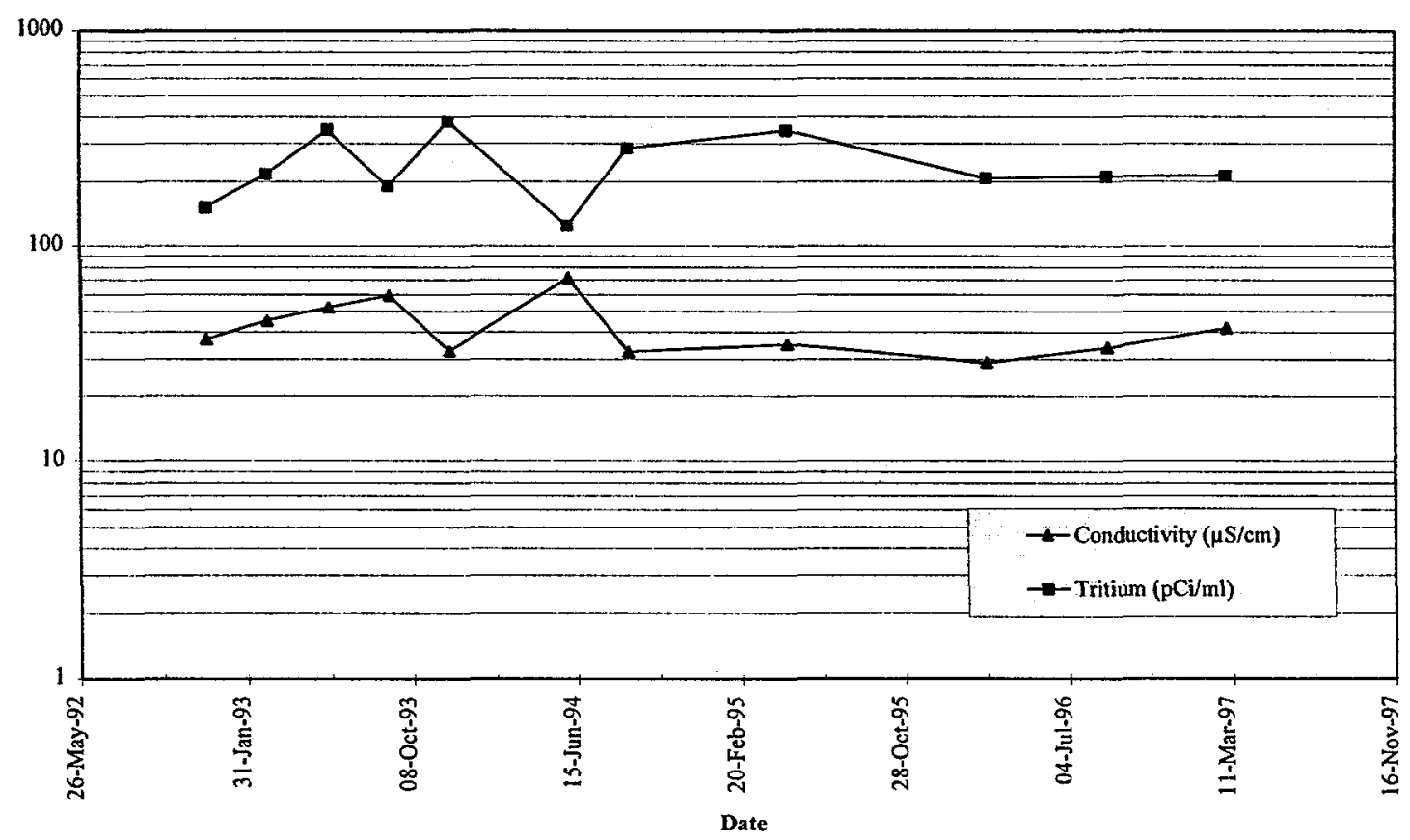


Sample Location FHB008

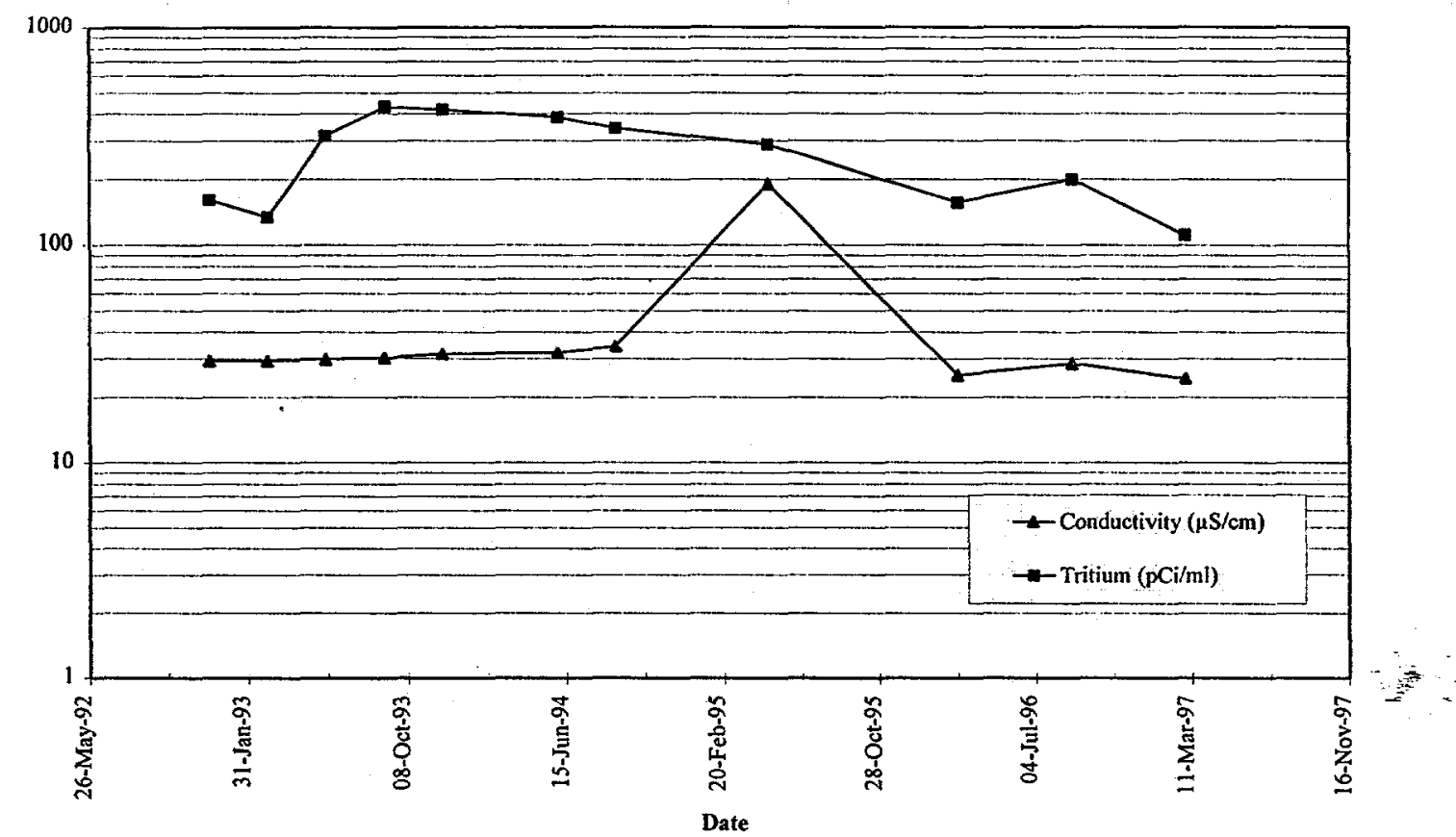

Sample Location FHB012 (stream)

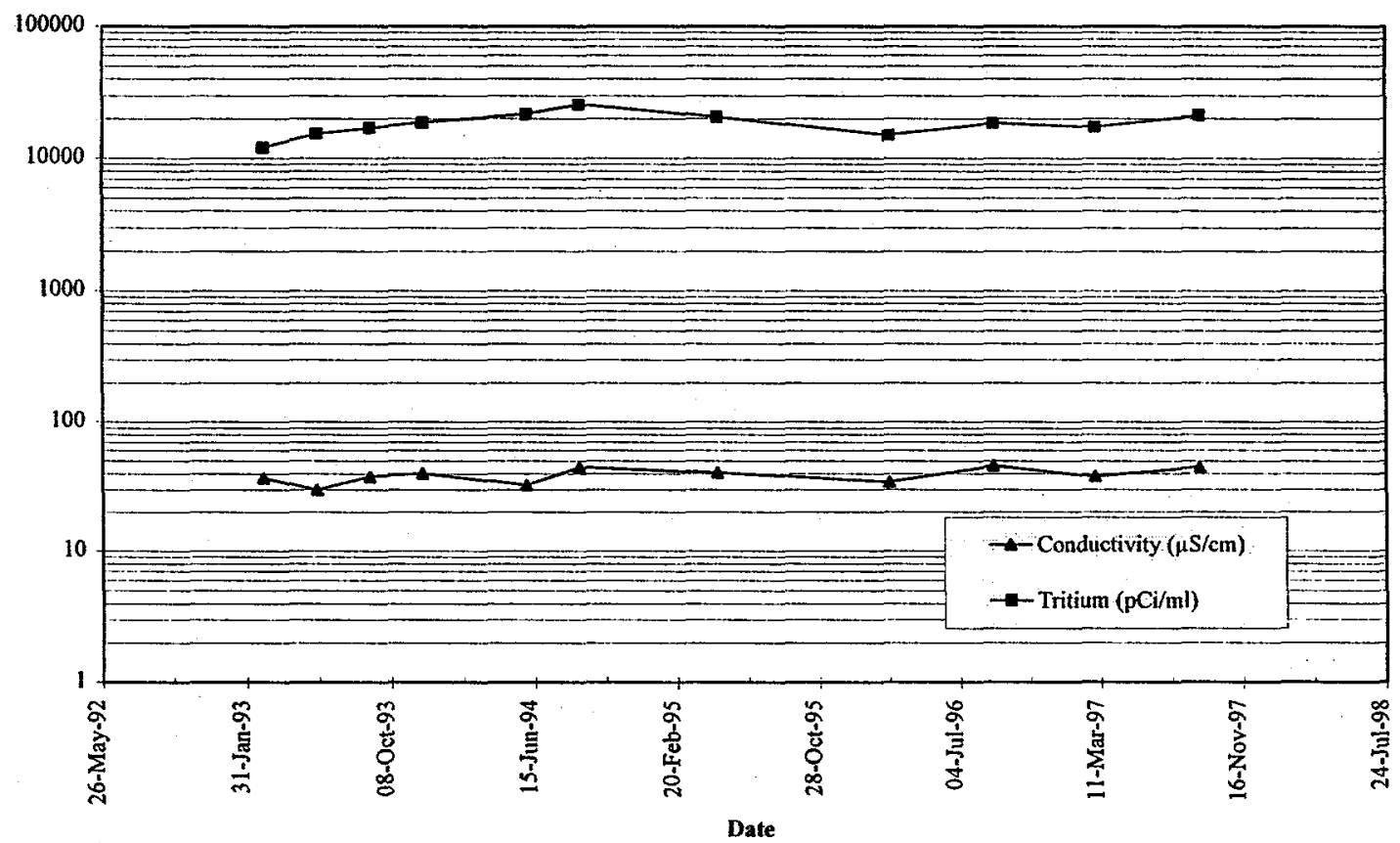




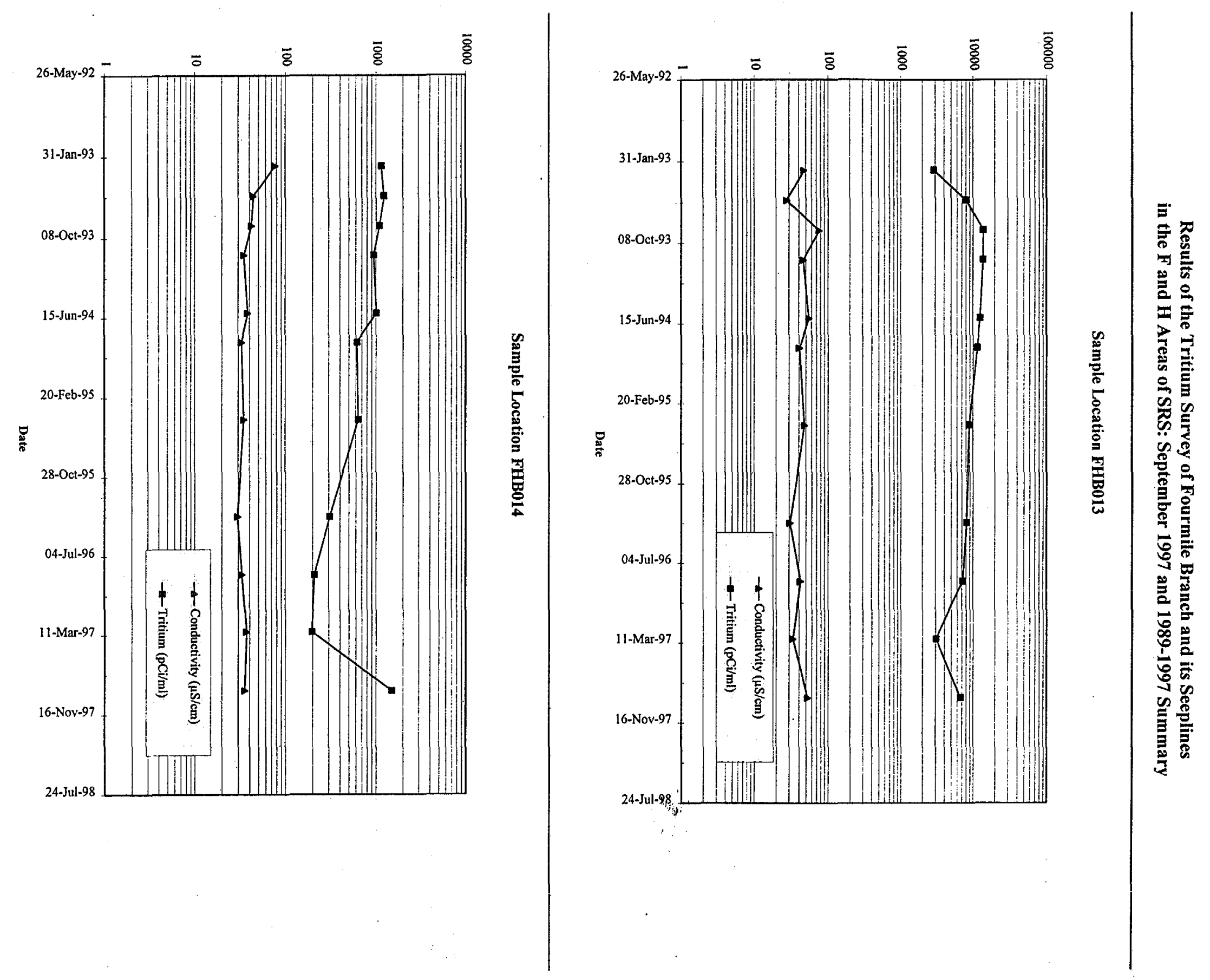




\section{Sample Location FHB015}

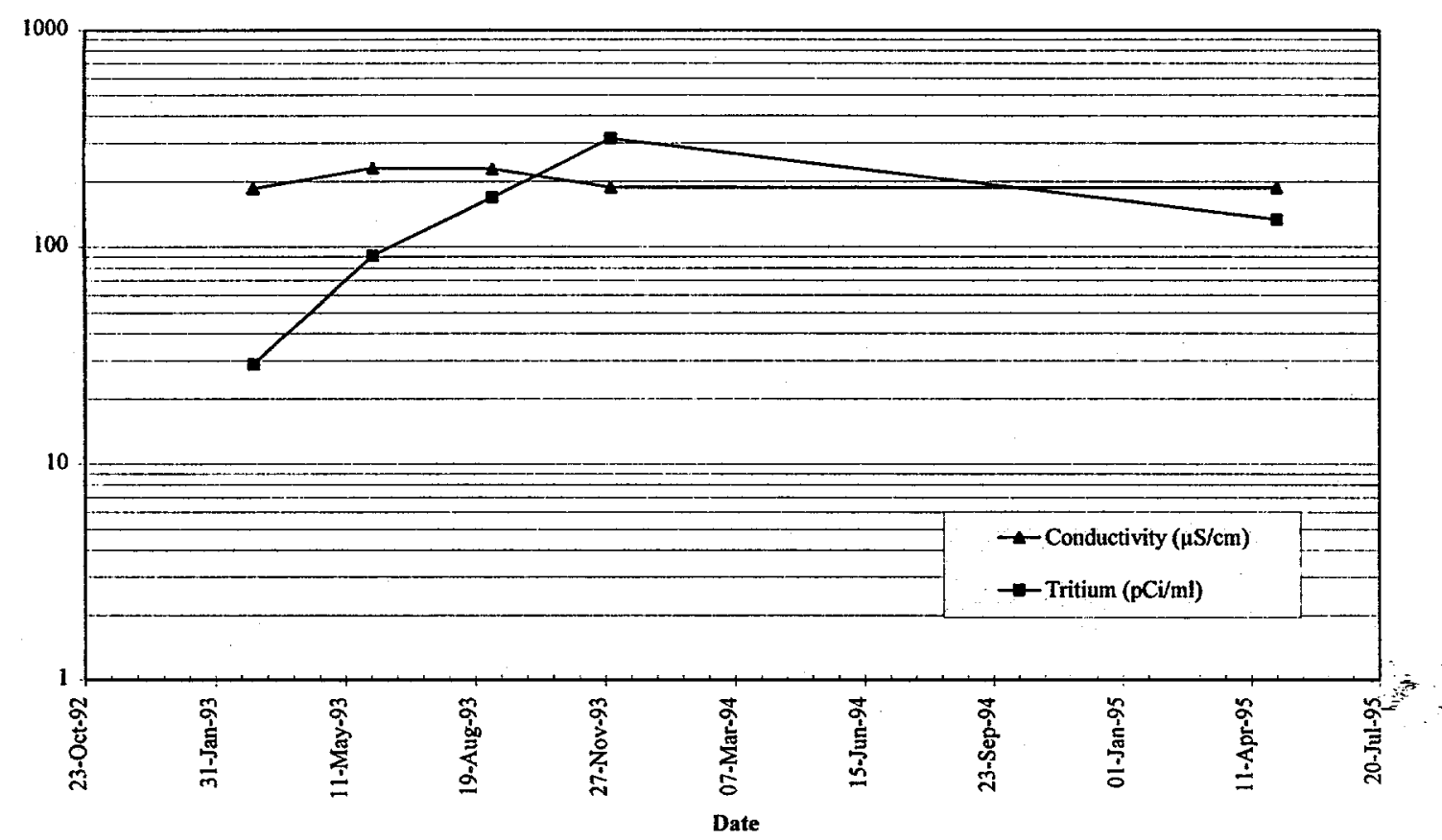

Sampel Location FHB016

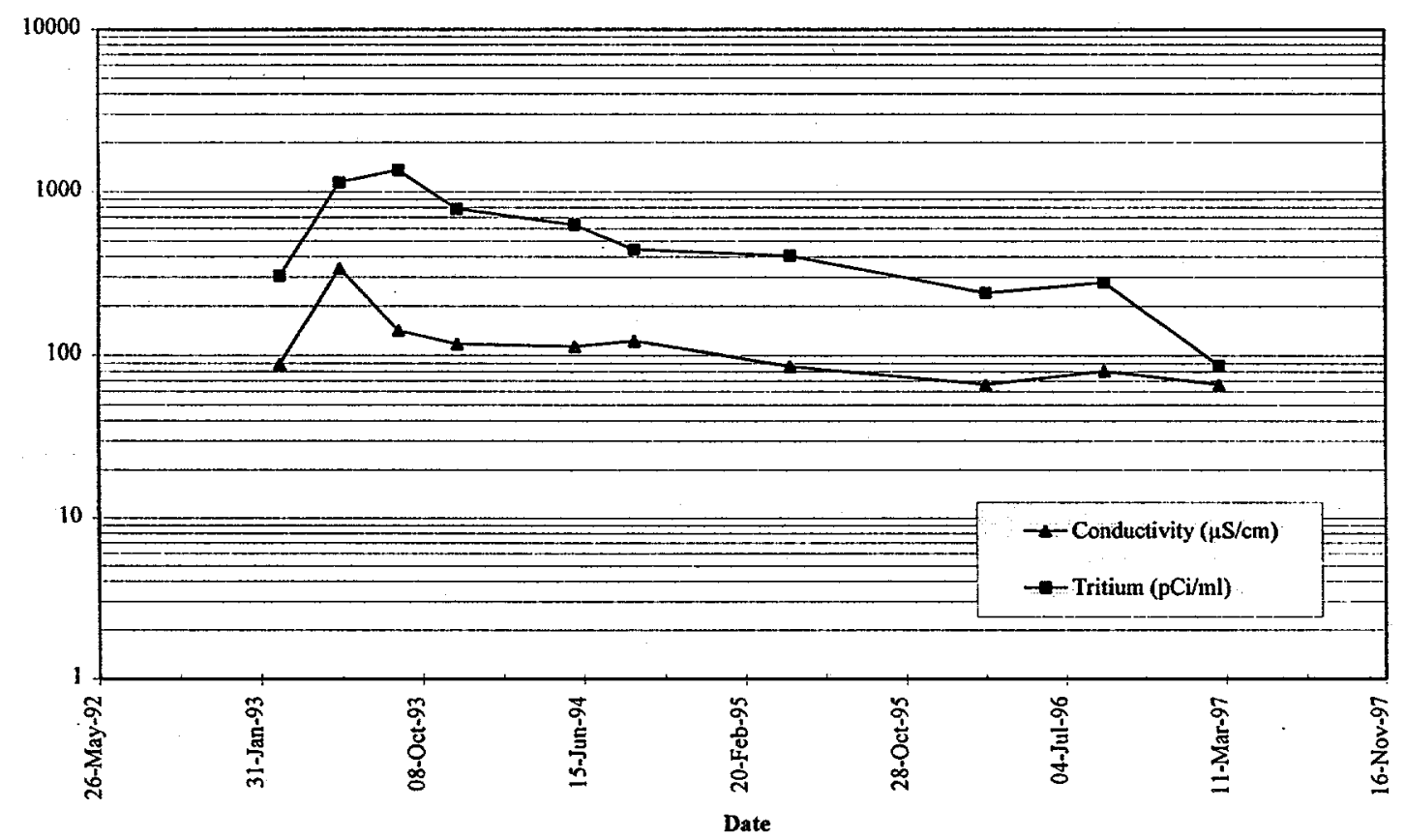


Results of the Tritium Survey of Fourmile Branch and its Seeplines in the F and $H$ Areas of SRS: September 1997 and 1989-1997 Summary

Sample Location FHB017

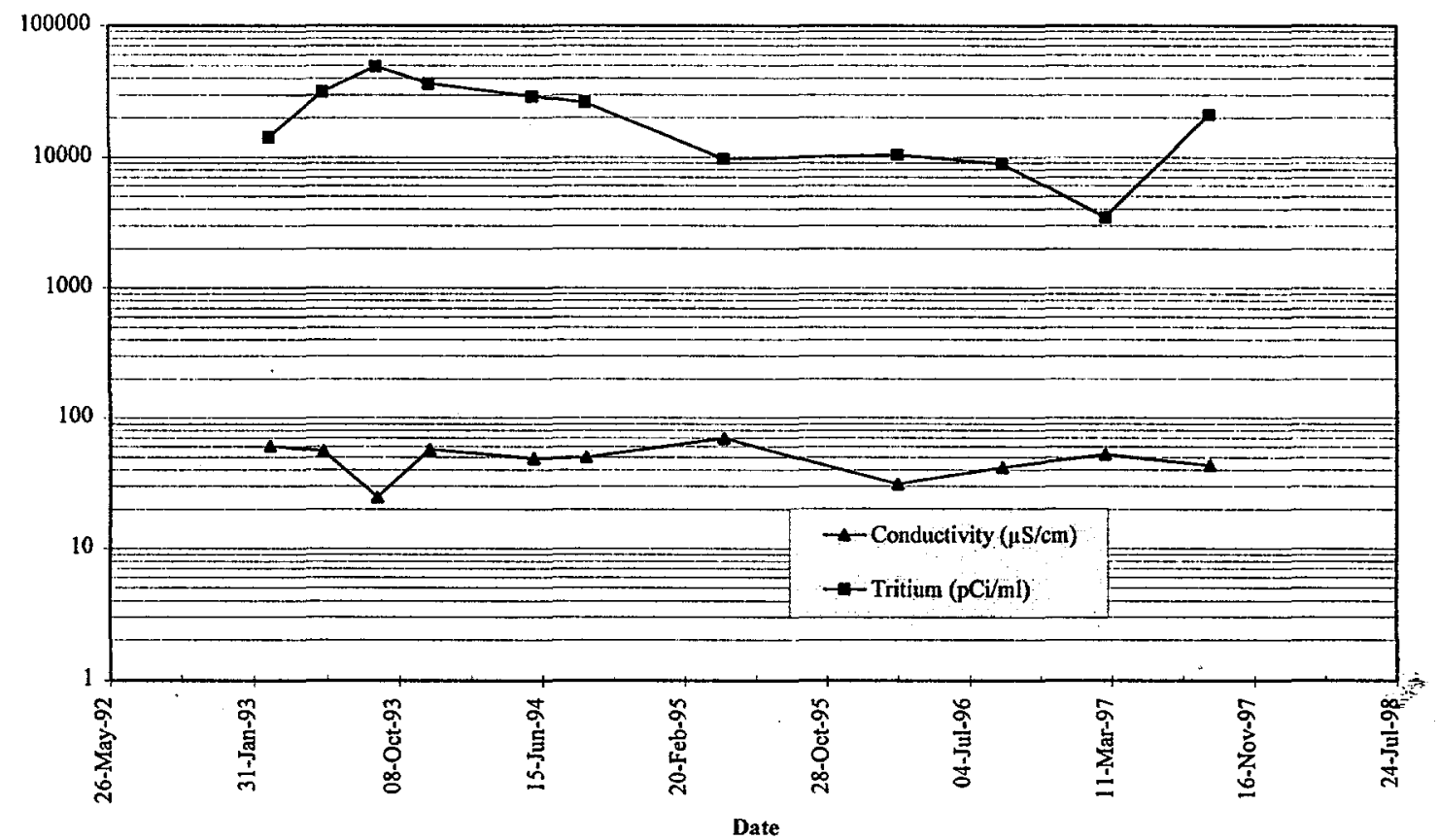

Sample Location FHB018

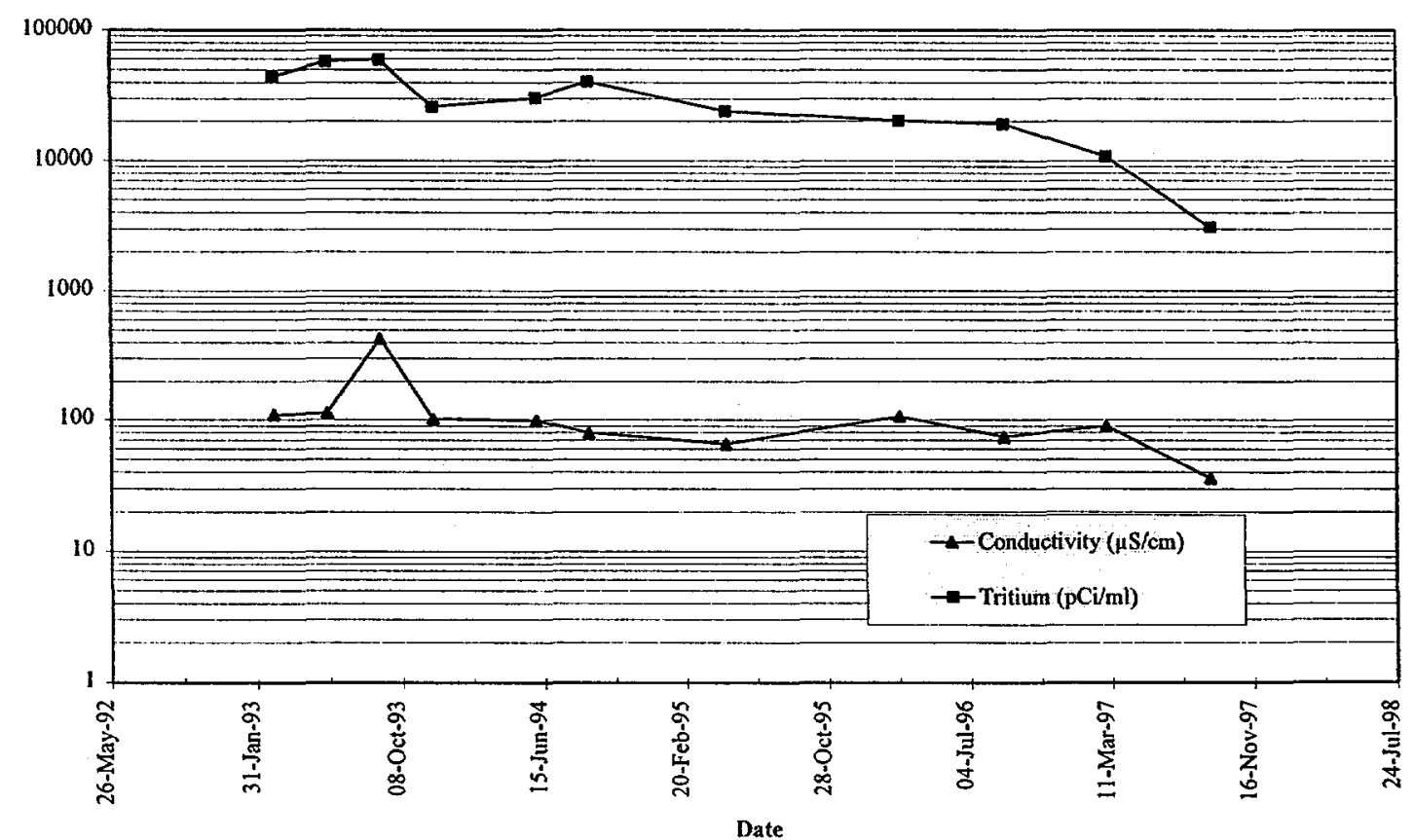


WSRC-TR-98-00365

Sample Location FHB019

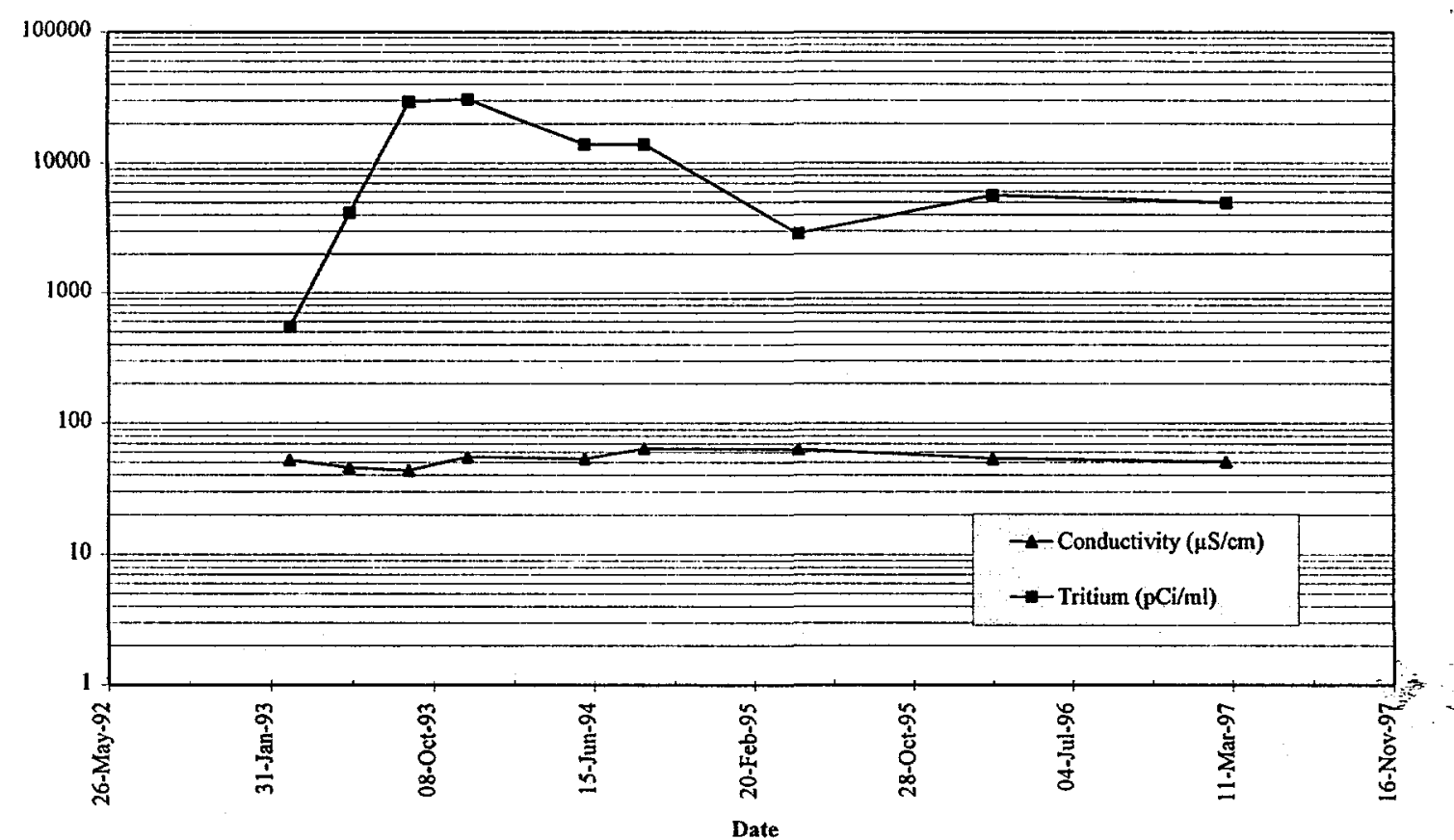

Sample Location FHB020

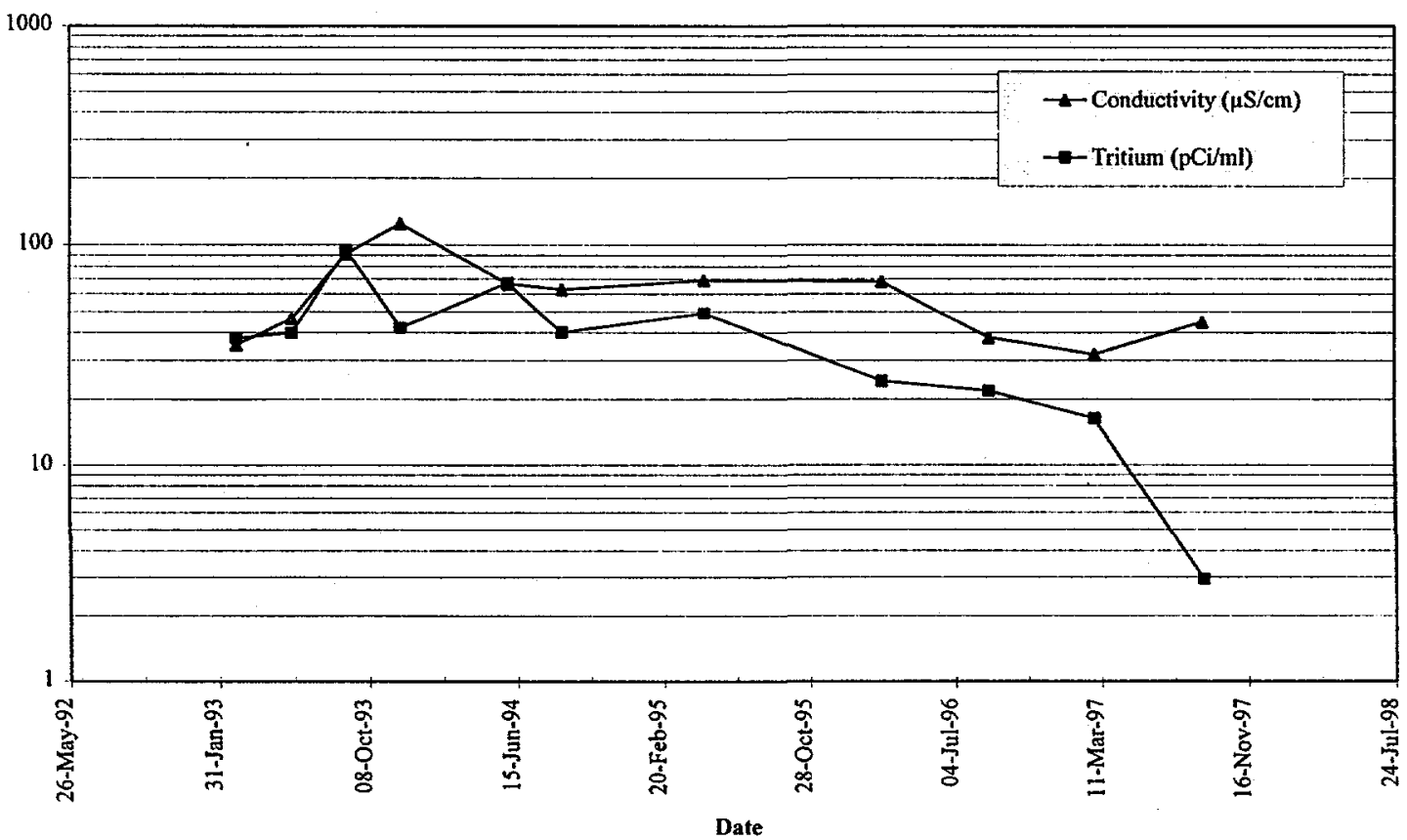




\section{Appendix D}

Fourmile Branch

Tritium Concentrations and Conductivity Plotted by Sampling Location, 1992-1997 

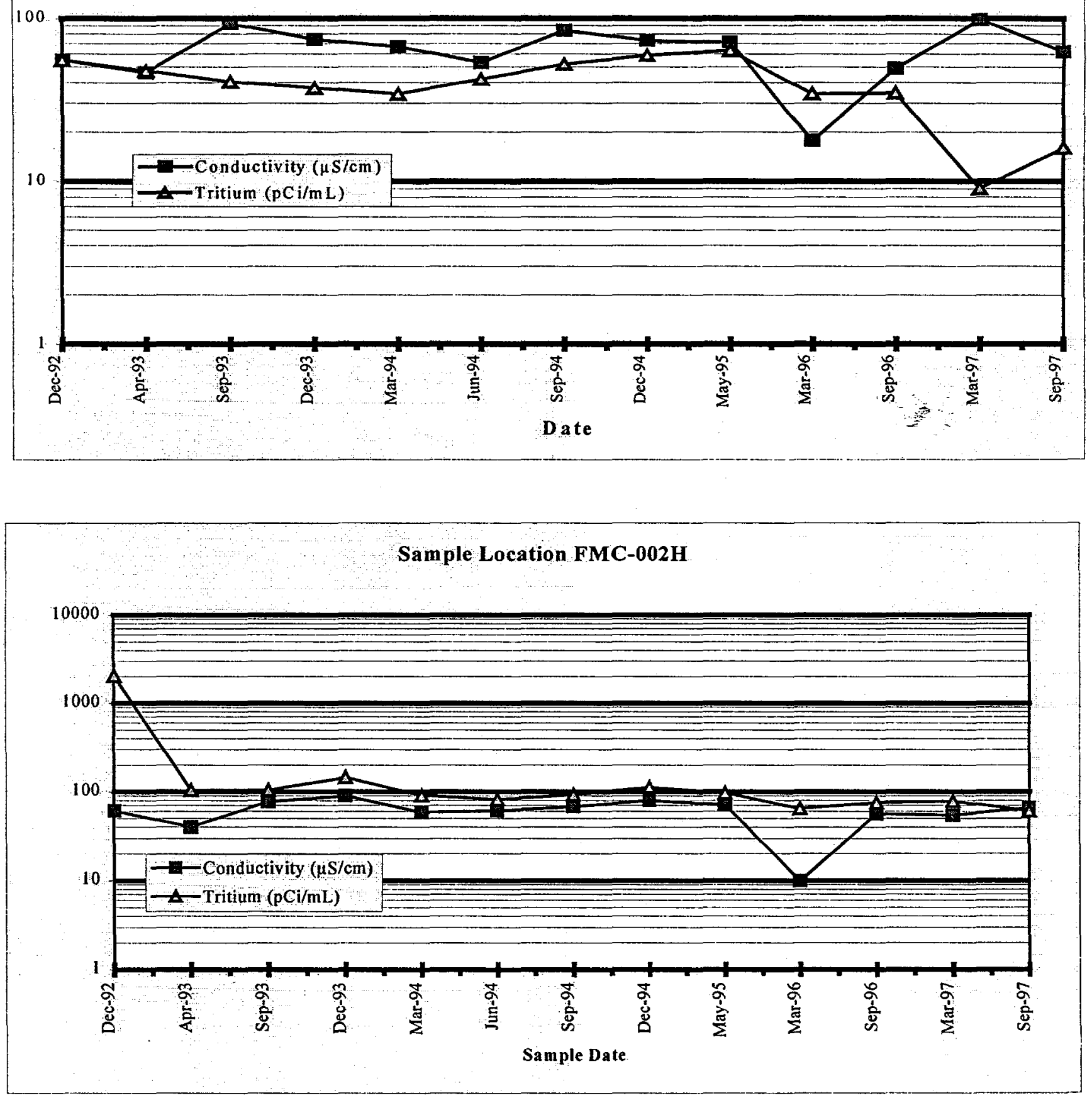
Results of the Tritium Survey of Fourmile Branch and its Seeplines in the F and $H$ Areas of SRS: September 1997 and 1989-1997 Summary

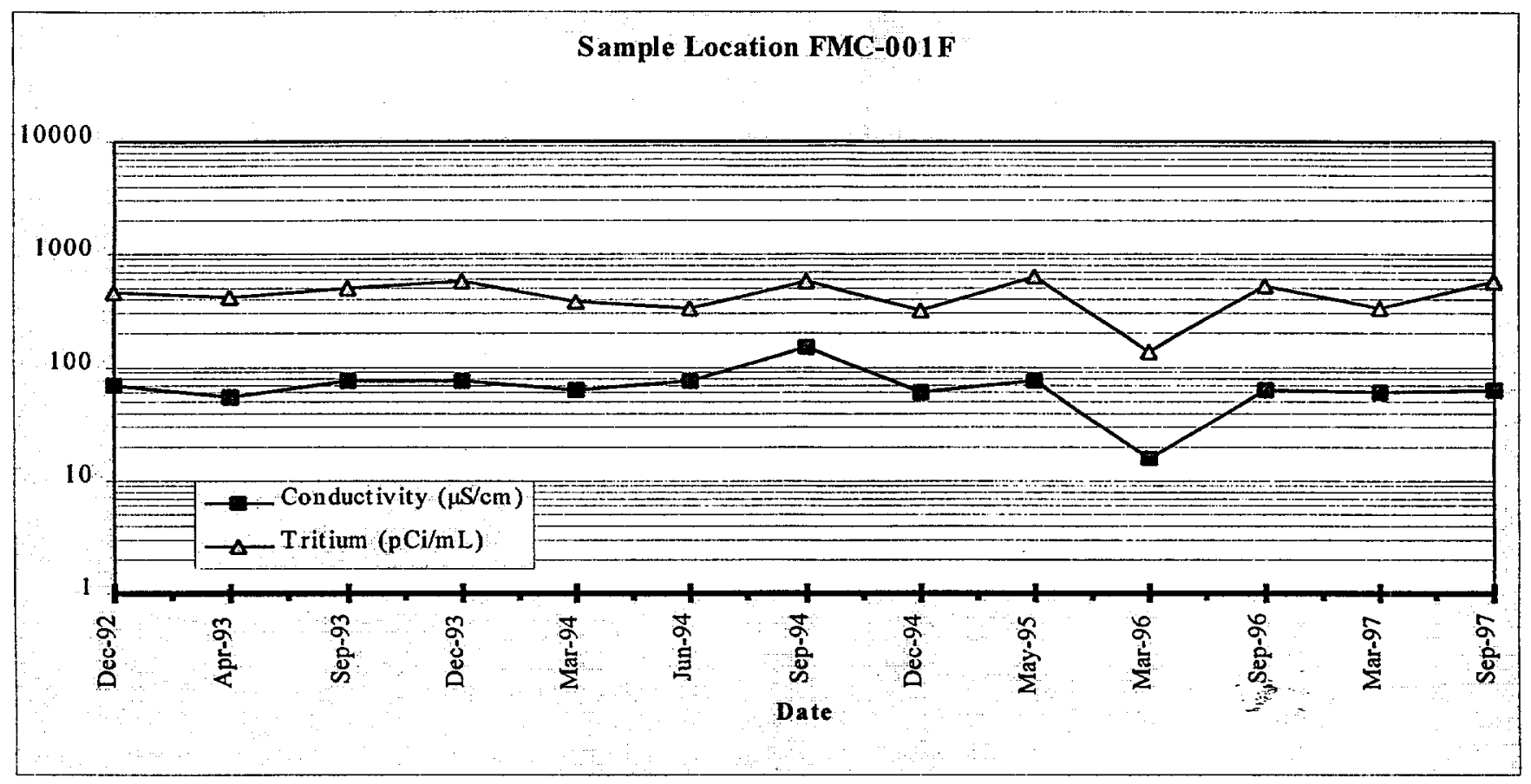

